Maurício de Oliveira Maas

MÚSICA CORPORAL E JOGOS MUSICAIS CORPORAIS

Um estudo das práticas do grupo Barbatuques na

educação musical do artista teatral

São Paulo

2018 
Maurício de Oliveira Maas

\title{
MÚSICA CORPORAL E JOGOS MUSICAIS CORPORAIS \\ Um estudo das práticas do grupo Barbatuques na \\ educação musical do artista teatral
}

\begin{abstract}
Dissertação apresentada ao Programa de Pós-Graduação em Artes Cênicas da Escola de Comunicações e Artes da Universidade de São Paulo sob orientação do prof. Dr. Fábio Cardozo de Mello Cintra, área de Concentração em Pedagogia do Teatro, linha de pesquisa Formação do Artista Teatral, como exigência para a obtenção do título de Mestre em Artes da Cena.
\end{abstract}

\section{VERSÃO CORRIGIDA}

A versão original se encontra disponível tanto na Biblioteca da ECA-USP quanto na Bibloteca Digital de Teses e Dissertações da USP (BDTD)

São Paulo 


\section{FOLHA DE APROVAÇÃO}

Maurício de Oliveira Maas

Música corporal e jogos musicais corporais: um estudo das práticas do grupo Barbatuques na educação musical do artista teatral

Dissertação apresentada ao Programa de Pós-Graduação em Artes Cênicas da Escola de Comunicações e Artes da Universidade de São Paulo para a obtenção do título de Mestre em Artes da Cena.

\section{APROVADO EM:}

\section{BANCA EXAMINADORA}

Prof. Dr.

Instituição

Assinatura

Prof. Dr.

Instituição

\section{Assinatura}

Prof. Dr.

Instituição

\section{Assinatura}


Este trabalho é dedicado a Fernando Barba, Stênio Mendes Nogueira e Antônio Januzelli, o Janô. 


\section{Agradecimentos}

Em primeiro lugar louvo e agradeço a cada um dos meus ancestrais que, na somatória de suas ações e escolhas, proporcionaram a minha chegada até aqui.

Ao meu orientador Prof. Dr. Fábio Cintra, querido mestre, parceiro e amigo de olhar apurado e escuta elevada que, desde o meu tempo de graduação, sempre foi uma grande fonte de inspiração e incentivo sobre os meus estudos da musicalidade no teatro.

Ao Mestre Fernando Barba que, pela força de sua criação, inspirou uma transformação do mundo, e pela generosidade do convite que transformou também o rumo da minha história.

Ao Mestre Stenio Mendes, que através de sua mágica e luminosa força musical, me trouxe tanta inspiração superior, me ensinando o infinito exercício do ouvir, sentir e manter o outro.

Ao Mestre Janô por, entre tantas coisas, ter me apresentado o caminho do Ator ao Homem, me auxiliando assim a escutar melhor o que vinha de dentro, fazendo eu chegar até aqui.

Aos barbatucos/as mestres, professores e parceiros de caminhada de hoje e de sempre: André Hosoi, André Venegas, Bruno Buarque, Charles Raszl, Dani Zulu, Giba Alves, Helô Ribeiro, Flávia Maia, João Simão, Lu Cestari, Lu Horta, Luíz Gayotto, Mairah Rocha, Marcelo Pretto, Renato Epstein e Tais Balieiro. Cada um de vocês me ensinou muito do que sou hoje. Grato! Ao Núcleo Educacional Barbatuques, em nome de Fernando Barba, Stenio Mendes, André Hosoi, Giba Alves e todos que colaboraram, durante horas e horas de reuniões e pesquisas, onde sem a sua existência, não seria possível a realização desta dissertação.

À minha família musical da ULM e do Núcleo Orgânica Performático, além de todos os amigos, parceiros e pesquisadores semeadores em que tive a honra de estar junto na jornada.

Aos professores e mestres, pérolas preciosas que encontrei durante minha caminhada escolar e acadêmica, que me apontaram os caminhos necessários. Em especial ao meu professor de artes Ibrahim, querido incentivador, aos meus professores de teatro Robson e Mauro, aos meus mestres acadêmicos do CAC, em especial Janô, Fábio Cintra, Malu Pupo, Ana Maria Amaral, Eduardo Coutinho, Clóvis Garcia, Cyro del Nero, Eudosia Acuña, Eudinyr Fraga, Hamilton Saraiva, Zebba dal Farra, Ingrid Koudela, Joaquim Gama, entre tantos outros.

À Mariana Loureiro por me incentivar a ir pela primeira vez em uma oficina de teatro.

À Escola de Arte Dramática (EAD), em nome de Isabel Setti e Rogério Toscano, pelos convites prazeirosos que tanto me auxiliaram no aprofundar as possibilidades do caminho Teatro-Música e do caminho Música-Teatro.

Ao amigo maestro Carlos Bauzys pelas tantas inspirações e oportunidades de firmar o estudo. 
A todos os grupos e núcleos artísticos em que colaborei: Raízes, Obara, Engenho Teatral, Tablado de Arruar, Cia. Circo Navegador, Cia. Do Quintal, Cia. dos Dramaturgos, Cia. Estelar de Teatro, Cia. Ausgang de Teatro, Cia. O Grito, entre outros. Agradeço pela oportunidade de aprofundar os muitos aprendizados de criação e de arte, seja como ator, músico, diretor musical, preparador ou compositor de trilhas sonoras.

A todos meus alunos, especialmente aqueles que participaram das oficinas por mim ministradas além dos alunos do curso de teatro musical do SESI SP e de música da faculdade Unisant'Anna, por me ensinarem que um bom professor é aquele que aprende ensinando.

Ao Zebba dal Farra e Carminda Mendes pelas sugestões, apontamentos e ricas colaborações durante minha qualificação, etapa necessária para a realização do presente mestrado.

Ao Maestro Marcello Amalfi pelas trocas preciosas de saber musical e pela tradução.

À Capes-PROEX pelo apoio fundamental para que esta pesquisa fosse possível.

A todos os integrantes da amada família Buscapé, pela inspiração e incontáveis "10 mais".

À minha família: minha mãe Leonor por toda a vida e música que existe em mim, à minha tia Teca, tia Ruth e tio Ruy pelas inesquecíveis cantorias musicais em volta dos violões, fonte primeira do meu saber musical, aos meus irmãos Alexandre, companheiro de sons e sonhos e Rita pela escuta sempre presente e generosa, aos meus primos Pedro, por me despertar a vontade de tocar violão, Gabi, Ana Luisa, Zé Lucas pela música sempre presente, aos meus antigos-novos familiares Fernanda, Gabriela e Fabiano pelo apoio e incentivo desde sempre. Ao meu afilhado-sobrinho Matheus e ao meu sobrinho João Américo, nascido no mesmo ano da conclusão deste trabalho. Agradeço ao tanto de amor que trouxeram à minha vida!!

Ao meu avô Walter que, além de aguçar minha curiosidade musical através do seu piano, me deu de presente, quando eu tinha 14 anos uma caixa (instrumento rítmico de fanfarra) que era de meu bisavô Alexandre, abrindo assim as primeiras portas do caminho dos batuques.

À minha tia Maria Luiza pelo generoso incentivo musical através de cursos e instrumentos.

Aos meu guias espirituais, mentores e mestres musicais, além dos irmãos e irmãs das medicinas da floresta, que tanto me ajudaram a abrir a portas das percepções musicais.

Em especial, agradeço à flor mais linda que encontrei, minha amada parceira, companheira de vida, de arte e de caminhada Jeyne Stakflett, pelo amor, carinho e paciência generosa, especialmente durante a escrita desta dissertação. Te amo!

Em memória do meu pai Alexandre e da minha avó e madrinha Jeanette, por me ensinarem tanto sobre a importância da generosidade, do amor, da espiritualidade e do respeito ao próximo e à natureza. 
De magia, de dança e pés De criança, cantor e mãos Alameda de gente vida Fecha e mata qualquer ferida

De carinho, de roda e mãos De esperança, de corpo e pés A paixão que me está surgindo Te tocando, me consumindo A pulsação do mundo é O coração da gente O coração do mundo é A pulsação da gente Ninguém nos pode impor, meu irmão O que é melhor pra gente 


\section{RESUMO}

A presente dissertação de mestrado propõe uma investigação sobre as possibilidades de aplicação das práticas de musicalização corporal desenvolvidas pelo grupo Barbatuques na educação musical do artista teatral. Este grupo, referência em percussão corporal, possui uma sólida pesquisa artística e pedagógica, iniciada em 1997, na qual utiliza o corpo como instrumento musical, através de atividades nas quais o aspecto lúdico é preponderante. $\mathrm{O}$ objetivo principal desta dissertação é apresentar os principais jogos desenvolvidos pelo grupo, propondo uma análise reflexiva sobre seu uso e aplicação no ensino de teatro. Esta pesquisa pretende colaborar como uma ferramenta possível para a educação musical do artista teatral.

Palavras-chave: Barbatuques; percussão corporal; música corporal; educação musical; jogos musicais; jogos teatrais; treinamento musical de atores. 


\begin{abstract}
This master's degree dissertation investigates into the possibilities to apply the corporal musicalization practices developed by the body percussion group Barbatuques in music education for theater artists. This leading group has a solid artistic and pedagogical research, started in 1997, based on the use of the body as a musical instrument through activities in which the ludic aspect is preponderant. The main objective of this dissertation is to present the most important games developed by the group, proposing a reflexive analysis on its use and application in theater teaching. This research also intends to collaborate as a possible tool in musical education for theater artists.
\end{abstract}

Keywords: Barbatuques; body percussion; body music; musical education; musical games; theater plays; musical training for actors. 


\section{SUMÁRIO}

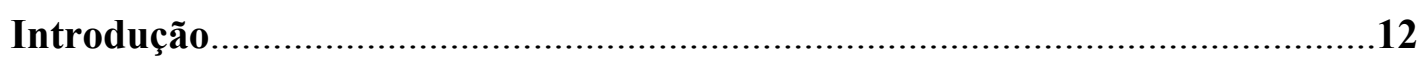

Infância: objetos mágicos e o antigo teatrinho.......................................................14

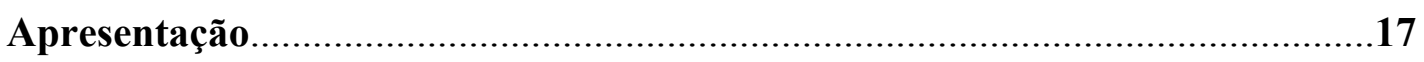

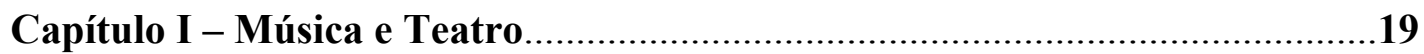

1.1 O corpo e a educação musical...............................................................19

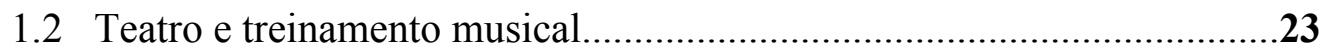

1.3 Barbatuques e treinamento musical para atores...................................25

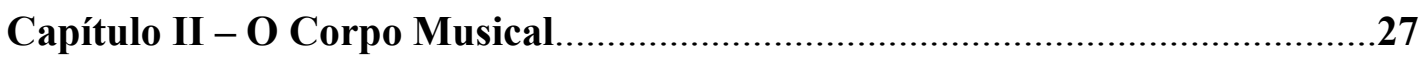

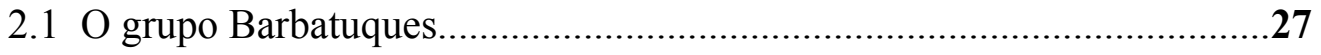

2.1.1 O Núcleo Educacional...........................................................29

2.1.2 O Núcleo Artístico...................................................................30

2.1.3 A pesquisa e o encontro com a academia..................................31

2.2 Os três Centros Sonoros......................................................................32

2.2.1 Sons corporais e o gesto teatral.............................................35

2.2.2 Centro Sonoro dos pés.........................................................36

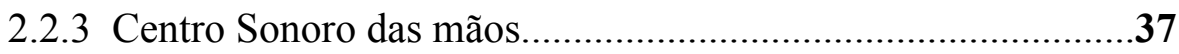

2.2.4 Centro Sonoro da boca...........................................................44

2.3 Notação musical - tablaturas e partituras................................................47

Capítulo III - Jogos Musicais Corporais..................................................54

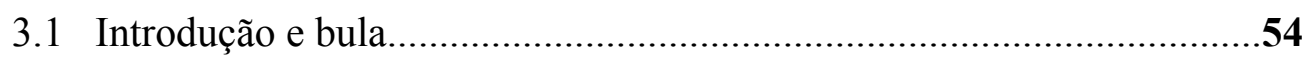

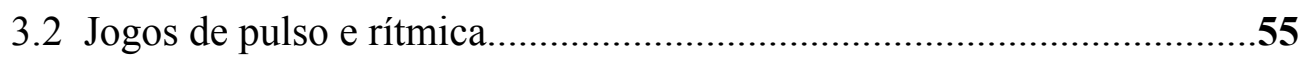

3.2.1 Jogo do Caminhar: pulso, andamentos e intensidades utilizando o Centro Sonoro dos pés.....................................................55

3.2.2 Jogo do Caminhar: pulso, andamentos e intensidades utilizando combinações entre os três Centros Sonoros............................67

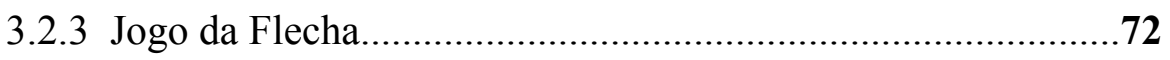

3.2.4 Jogo de Flecha e os Três Centros Sonoros............................87

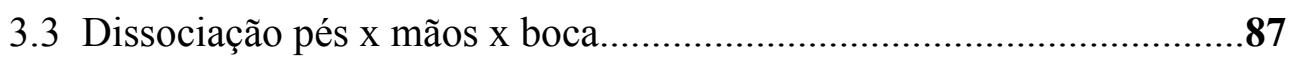


3.4 Jogos de Composição, Regência e Improvisação..................................92

3.4.1 Jogo do Eco........................................................................92

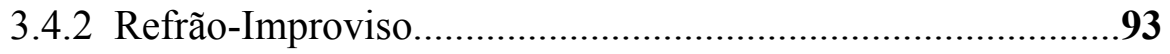

3.4.3 Carrossel (Jogo do maestro)..............................................96

3.4.4 Sequência Minimal.............................................................97

3.4.5 Contágio livre (Improvisão) ............................................98

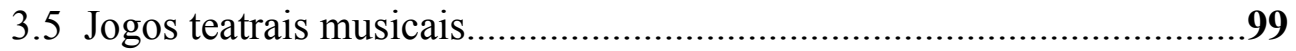

3.5.1 Flecha rítmica com palavras e textos...................................99

3.5.2 Jogo do Espelho Sonoro (som e movimento).........................99

3.5.3 Jogo da Engrenagem Sonora..............................................100

3.5.4 Jogo da Paisagem Sonora..................................................101

3.5.5 Jogo da História Sonorizada..............................................102

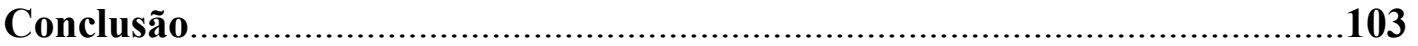

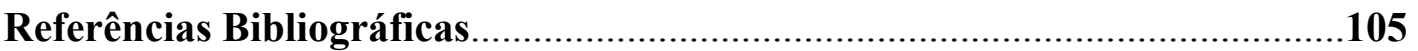

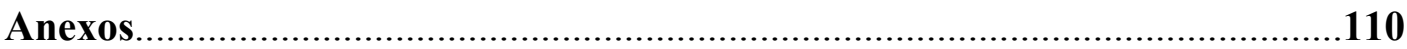

Entrevista com Stênio Mendes........................................................................111

Entrevista com Carlos Bauzys........................................................................116

Sinais regência (concepção e desenho: Stênio Mendes)..........................................126

Primeiras notações musicais (Fernando Barba e André Hosoi)............................132

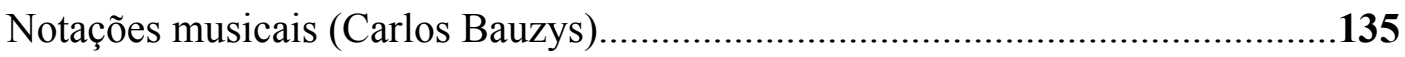

Barbapapa's Groove (Fernando Barba) - transcrição:Carlos Bauzys....................138 


\section{INTRODUÇÃO}

Eram meados do ano 2000. Eu já estava cursando o quarto ano de Licenciatura em Artes Cênicas da Escola de Comunicação e Artes da USP quando tive contato pela primeira vez com a linguagem da percussão corporal. Naquela época, era cada vez mais comum receber convites dos colegas da graduação para participar de peças, cenas e exercícios teatrais, não tanto como ator, e sim como músico, preparador musical ou algo relacionado ao universo da música. Reconheço que inicialmente isto me incomodava um pouco, afinal para mim, a música era algo natural e despretensioso, e o meu objetivo na época era me dedicar aos estudos das artes da cena tanto como ator quanto professor. Entretanto como sempre estava acompanhado de um violão, um instrumento de percussão ou acordeon, os convites musicais para participações no teatro começaram a aumentar naturalmente.

Foi então que vi a divulgação de uma oficina chamada "Percussão corporal e sonoridades em sucata" na Universidade Livre de Música em São Paulo. Na época faltava um ano e meio para terminar a minha graduação e estava fazendo uma pesquisa de iniciação científica pela FAPESP sobre Teatro de Animação e Formas Animadas, supervisionada pela prof. Dra. Ana Maria Amaral. Confesso que o que mais me chamou a atenção no título da oficina foi justamente a palavra "sucata", afinal, poderia ser bastante enriquecedor juntar instrumentos musicais reciclados com a pesquisa que eu estava fazendo sobre bonecos, máscaras e objetos animados.

A oficina era ministrada simultaneamente por dois professores. O responsável por coordenar a parte dos instrumentos de sucata era o Stenio Mendes e a parte da percussão corporal, o Fernando Barba, diretor do grupo Barbatuques, de quem até então eu nunca tinha ouvido falar. Quando ele tocou na minha frente uma pequena peça musical utilizando o corpo como intrumento, onde combinava ritmicamente de maneira harmoniosa o uso de estalos de dedos, palmas, batidas no peito e sons na boca, senti uma sensação da qual jamais me esquecerei. Fiquei emocionado ao mesmo tempo em que comecei a dar risadas, parecia que estava sentindo cócegas. Soube naquele momento que algo mágico tinha acontecido, um portal de inúmeras possibilidades musicais havia sido aberto me revelando uma poderosa ferramenta de transformação artística. Algo me disse que minha vida mudaria a partir dalí.

Descobri logo na sequência que o Stenio Mendes era muito mais do que um mero construtor de instrumentos de sucata. Ele era simplesmente um grande mestre, pesquisador nas inúmeras sonoridades vocais e fonéticas, grande estudioso das possibilidades de 
improvisação musical e profundo conhecedor da linguagem da música orgânica ${ }^{1}$ e instintiva ${ }^{2}$. Além de tudo isso, Stenio foi a pessoa que inspirou o Fernando Barba a aprofundar sua pesquisa da percussão corporal e consequentemente, a criar e fomentar o grupo Barbatuques.

Pensei que conhecer e conviver com estes dois mestres me auxiliaria a entender melhor e aprofundar um pouco mais a minha pesquisa musical. Hoje percebo que aprendi muito mais do que isso e venho compartilhar um pouco destas descobertas na presente dissertação.

Logo na sequência, em 2001, Fernando Barba me convidou para fazer parte do Barbatuques. Paralelamente com o trabalho de shows e oficinas do grupo, continuei a dar aulas de teatro em escolas além de ocasionalmente colaborar com grupos teatrais, seja participando como músico, ator, compositor de trilhas ou preparador musical.

Começei a ter oportunidades de ministrar oficinas de percussão corporal para atores. Os jogos musicais corporais sempre foram muito bem recebidos por este público formado por artistas que também utilizam o corpo como instrumento de expressão. Percebi que muitos deles possuiam conhecimentos musicais de um modo mais intuitivo e que estes jogos tinham a capacidade de colaborar com o estudo de suas próprias musicalidades. Foi então que comecei a perceber como poderiam ser ricas as possibilidades de misturar a pesquisa da percussão corporal com o universo teatral. Pude observar que estes jogos, através do seu caráter lúdico, podem auxiliar na evolução da expressão e criatividade musical de cada ator jogador. Foi quando comecei a pensar que toda esta metodologia desenvolvida pelos Barbatuques poderia colaborar com a educação musical do artista da cena.

Deste modo, após quinze anos de pesquisas e estudos resolvi voltar à universidade para registrar e compartilhar um pouco do que vivenciei em todos estes anos. A presente dissertação de mestrado é fruto deste trabalho.

\footnotetext{
1 O termo "Música Espontânea" não possui um registro acadêmico que o conceitue. O professor Stênio Mendes

2 De acordo com o professor Stênio Mendes, o termo "Musicalidade Instintiva" nasceu de sua tese de que o homem nasce com uma musicalidade inata, instintiva. Segundo Stênio, no desenvolvimento da razão o homem "é adestrado, educado, se adapta para o convívio social, que em parte está baseado na repressão de impulsos instintivos. E através da Arte, acredita-se, podemos nos "reconectar com a nossa natureza mais instintiva, afetiva, no exercício e aprofundamento da nossa sensibilidade...” (DI LUCA, 2011, p. 50)
} 


\section{Infância: objetos mágicos e o antigo teatrinho}

Minhas lembranças sonoras mais antigas estão relacionadas a três objetos mágicos e misteriosos: uma vitrola que minha família tinha em casa, o piano do meu avô e o violão de minha mãe. Quando algum deles começava a soar, sentia, ao meu modo de criança, que acontecia algo diferente comigo e com o ambiente ao meu redor mas não sabia explicar o que era. Quando escutava discos na vitrola, meus pensamentos eram preenchidos por diversas imagens e sentimentos. Estas sensações se amplificavam principalmente quando a minha querida tia Teca, irmã de minha mãe, se juntava com mais um violão e ficávamos em família tocando e cantando as mais diversas músicas durante horas. Timidamente eu tentava acompanhar com chocalhos, garrafas pet, papel celofane ou outros objetos que, no meu perceber, possuiam uma sonoridade agradável e harmonizavam com o que estava sendo tocado.

Também preciso falar de meu avô paterno que era um excelente pianista mas extremamente cuidadoso: não gostava que os netos pequenos mexessem no seu piano. Logicamente eu, por diversas vezes ficava escondido, espreitando aquele magnífico instrumento, esperando a oportunidade para poder dedilhar aquelas teclas amareladas de marfim. Até hoje consigo lembrar do cheiro característico da madeira que exalava dele. Foi neste piano, escondido, que aprendi a reconhecer as primeiras notas musicais.

Estudei no Liceu Salesiano, uma escola imensa com diversas instalações, situada em Campinas - SP. Entretanto, o local que mais me chamava a atenção era um velho teatro de madeira, mofado e cheio de bolor, que ficava bem no meio da escola, cercado por campos de futebol e diversas quadras poliesportivas.

Quando completei oito anos, minha classe foi convidada para ver uma apresentação teatral lá. Lembro como se fosse hoje a sensação de entrar, ver todas aquelas cadeiras, o palco, coxias e assistir um espetáculo teatral pela primeira vez. Para mim era mágico, divertido mas não sabia se o que estava acontecendo era real ou não. Essa questão foi me envolvendo durante a peça até que em determinado momento um dos atores pergunta algo a outro ator. Não deu outra: fiquei de pé e ali mesmo, gritei bem alto para que ele ouvisse a resposta. Todos, público e atores, me olharam e fez-se então um silêncio desconcertante que para mim durou quase uma eternidade. Mesmo assim, saí de lá com a sensação de que o palco era um lugar realmente mágico e especial. 
Estava eu então com doze anos em sala de aula, nesta mesma escola, quando chega a notícia de que teríamos um festival musical de inglês! Funcionaria da seguinte forma: cada classe selecionaria alguns alunos. Estes, por sua vez, escolheriam uma música em inglês para cantar ao vivo por cima da gravação no dia do festival. É como se fosse um karaokê mas utilizando a versão original da música. As turmas dos anos mais adiantados poderiam ter a opção de cantar e tocar instrumentos ao vivo, o que não foi o nosso caso. Não me lembro como consegui, mas quando percebi já estava no grupo eleito de seis alunos e os ensaios já iriam começar. Representando a turma do $6^{\circ} \mathrm{A}$, escolhemos "Hand in Hand", música tema no ano anterior das Olimpíadas de Seul, 1988.

$\mathrm{Eu}$, muito feliz de estar no grupo, fui todo animado para o ensaio. Foi então que as coisas começaram a ficar um pouco estranhas. Lembro de que quando comecei a cantar, todos me olharam de modo esquisito. Achei que tinha impressionado a todos e não dei muita atenção até que a professora veio no final do ensaio e pediu para que eu tentasse cantar com menos volume. No final do segundo ensaio, após os mesmos olhares, a mesma professora além do pedir para eu cantar mais suave, disse que eu estava com um problema sério de afinação. Eu não fiz a menor ideia do que ela quis dizer.

Chegou então o grande dia da apresentação e ela ocorreria justamente no palco daquele velho teatrinho empoeirado onde eu havia assistido um espetáculo pela primeira vez. O som que vinha da platéia era bastante forte, fazendo meu coração disparar (e é assim até hoje). Me lembro de como os outros alunos do grupo que iriam cantar comigo pareciam estar um pouco desconfortáveis em relação à minha presença. Estava prestes a subir no palco, lembrando daquela vez em que inocentemente fiz uma intervenção durante aquela apresentação teatral, quando o meu melhor amigo, que também ia cantar, veio até mim e muito seriamente disse: "Olha Maurício, acho que seria mesmo muito importante você se lembrar do que a professora disse. É só tentar não cantar muito alto”. Assim que ele disse isso, demonstrando preocupação, mudou subitamente o meu estado interno. Fiquei em alerta, experienciando aquele misto de sentimentos entre a minha repentina insegurança e aquela emoção de estar em cena pela primeira vez, vendo o teatro lotado. Assim que a música iniciou os seus primeiros acordes, veio à minha lembrança a imagem dos olhares de desaprovação que me dirigiram durante os ensaios, as palavras da professora e do meu amigo. Eu já estava de pé em frente ao microfone quando em uma fração de segundos, uma ideia me veio a mente,: simplesmente resolvi dublar a música inteira. Durante toda a apresentação, movimentei minha boca como se estivesse cantando mas não emiti um som sequer. Aos 
poucos, aquele meu estado inicial de insegurança foi se transformando. Comecei a achar tudo aquilo divertido enquanto olhava para o público com firmeza e tranquilidade, gesticulando e interpretando a canção através da expressão corporal. Eu sabia que estava fingindo cantar mas estava ali no palco de forma plena e verdadeira. De qualquer forma, não ganhamos o festival. Saí admirado e perplexo desta segunda experiência com o palco.

No senso comum o palco é um local estratégico onde se apresenta eventos de importância para coletividades que mereçam ser assistidos por muitas pessoas com o máximo de eficiência possível. Vejo um lugar propício para revelar, contagiar estados verticais da alma humana, priorizando atividades artísticas, ou atividades que promovam a dignidade humana. Como lugar também da empatia, o artista pode ter a experiência extraordinária de sentirse em comunhão com platéia, em estados psicológicos que consagram este local chamado palco. Mas vejo também como um lugar ancestral, ritualístico, quando as pessoas se colocam em círculo para que todos se enxerguem, se identifiquem como seres humanos e comunguem no instante presente (..) era o lugar da provação, lugar crítico, da experiência mais aguda e psicologicamente mais iluminada. Na construção e exposição de máscaras, o palco se torna fundamental, além de estar propício para o discernimento, é o lugar dos "insights" onde testemunhamos o "momento gênesis" do ator se transformando, recriando, esculpindo a si mesmo para a experiência da comunhão com o coletivo. (Entrevista concedida por Stenio Mendes, julho de 2018$)^{3}$

A escolha de ter dublado ou não me acompanhou por anos. Durante um bom tempo, tive dúvidas se devia ou não ter cantado. Hoje posso dizer que não ainda sei se foi a melhor escolha, mas percebo que foi uma boa escolha em relação àquela determinada situação apresentada. Mesmo sem ter cantado, eu estava completamente presente e entregue na ação de cantar. Achei muito curioso tudo o que aconteceu e resolvi investigar um pouco mais o assunto, me dedicando a estudar, a partir da adolescência as artes do palco.

\footnotetext{
${ }^{3} \mathrm{O}$ roteiro de entrevistas, assim com a sua transcrição estão no Anexo da presente dissertação.
} 


\section{APRESENTAÇÃO}

A proposta desta dissertação é apresentar e aprofundar alguns dos jogos musicais corporais pesquisados e utilizados pelo grupo Barbatuques propondo uma reflexão sobre seu uso na educação musical do artista teatral, estando este em formação ou não. Vale ressaltar que o termo artista teatral não abrange somente os atores e sim diretores, sonoplastas, iluminadores, cenógrafos, dramaturgos, enfim, todos aqueles que se dedicam às artes teatrais.

Do mesmo modo que os jogos teatrais contribuem para o desenvolvimento de inúmeras capacidades necessárias do artista teatral, os jogos musicais corporais podem ser pensados como uma forma de complementação desta sensibilização, podendo também ser pensado como treinamento. Neste sentido, a vivência e a prática destes jogos não busca um fim em si mas uma repetição e aprofundamento constante, por tempo indeterminado, onde o objetivo maior é justamente o treinar, praticar, desenvolver e aprimorar estas capacidades.

Através de sua simplicidade, podem aprofundar de forma prática e lúdica diversos elementos musicais, como a noção de pulso, a percepção rítmica, afinação, coordenação motora, noção temporal, criatividade, sensibilidade, expressividade, escuta, atenção, intuição, estado de jogo, criação, composição musical e improvisação.

Após me apresentar junto com o grupo Barbatuques pelas várias regiões do Brasil e diversos países, percebi que a música corporal tem um efeito muito interessante nestes públicos, primeiramente pela curiosidade e espanto que causam. Parece que este efeito é universal. As pessoas percebem que o acesso ao instrumento é imediato porque se dá através do próprio corpo. É como se, de repente, as pessoas descobrissem que possuem um novo brinquedo, mesmo ele estando lá, adormecido por todo este tempo.

Como integrante do grupo Barbatuques, pude aprofundar no decorrer destes anos uma experiência prática não somente na parte artística, me apresentando em shows e eventos, mas principalmente na parte pedagógica, onde tive a oportunidade de ministrar oficinas e workshops para os mais variados públicos, especialmente para atores e estudantes de teatro, devido à minha formação. Durante os quinze anos em que estive fora da vida acadêmica, tive a oportunidade de desenvolver e executar toda a parte prática, que hoje está presente nesta pesquisa, através de aulas e encontros específicos para os artistas da cena. Tive a experiência de trabalhar por três anos como professor da Disciplina "Percussão Corporal" no curso de Graduação e Licenciatura em Música da faculdade UniS'antana, na cidade de São Paulo. Eram aulas práticas com uma média de oitenta alunos por turma e tinha a duração de um 
semestre. Também sou professor especialista desde 2014 no Curso de Formação em Teatro Musical do SESI-SP, onde coordeno a disciplina "Percussão corporal", que tem a duração um ano.

Pude perceber, em meio a tantas aulas por mim ministradas, como a percussão corporal e os jogos musicais corporais são extremamente benéficos na educação musical do ser humano. Senti isto especialmente quando trabalhei estes conteúdos com os artistas teatrais pois, como também utilizam o próprio corpo como instrumento de ação e expressividade, observei que este caminho de aprendizado ocorre especialmente neles de modo mais dinâmico, fluido e natural. Este processo acontece primeiramente em um nível prático de experimentação e vivência corporal para em seguida, através das reflexões sobre as práticas, perceber e entender os processos de apropriação dos conteúdos musicais.

Combinar estes jogos com outros já existentes no teatro, pode trazer oportunidades inimagináveis de descobertas do fazer teatral, colaborando de maneira direta com o desenvolvimento artístico através da prática e da reflexão sobre a percussão corporal e jogos musicais corporais. As técnicas de percussão corporal e jogos musicais corporais podem ser consideradas uma ferramenta bastante valiosa, útil e poderosa no desenvolvimento musical do artista teatral.

Existem duas entrevista no anexo desta dissertação. Uma delas é com o maestro Carlos Bauzys que além de ser pesquisador da linguagem da percussão corporal, é responsável pela criação de um sistema de notação musical para registrar este tipo de música e sonoridade. A outra entrevista é com Stenio Mendes, um dos grandes colaboradores e inspiradores da pesquisa de timbres, sononoridades, jogos e improvisações praticadas pelo grupo Barbatuques.

A presente dissertação de mestrado não tem a pretensão de desenvolver um curso completo de música nem de apresentar uma metodologia dentro de um curso de artes cênicas mas sim utilizar as técnicas aprimoradas pelo grupo Barbatuques dentro da formação do artista teatral de maneira simples, clara e acessível.

Este estudo pretende também colaborar com eventuais lacunas existentes nos processos de educação musical vivenciados pelo artista teatral até então, contribuindo deste modo para uma formação mais completa e coesa, além de proporcionar uma ferramenta disponível e inovadora. Estes jogos são um convite para o artista teatral investigar as possibilidades desta nova linguagem que propõe uma volta às origens, à fonte primária artística e sonora de todos, utilizando um conhecido instrumento de trabalho: o próprio corpo. 


\section{CAPÍTULO I - MÚSICA E TEATRO}

\section{O corpo e a educação musical}

Eu acho que música é uma capacidade humana. Ponto. Assim como fazer conta, como falar, andar, enfim, é uma capacidade humana e deve ser desenvolvida para um ser humano melhor. Assim como um dia, a maioria dos seres humanos não sabia fazer contas, hoje a maioria sabe fazer contas e isto deixou uma civilização melhor, mais avançada. Também acho que deveria ser assim com a música. É uma habilidade humana, uma capacidade humana que deve ser desenvolvida por todos para uma civilização melhor. (Entrevista concedida por Carlos Bauzys, julho de 2018) ${ }^{4}$

Em todas as culturas e civilizações de todas as épocas, existem registros relacionados à presença da música. Neste sentido, podemos dizer que provavelmente o corpo humano é o instrumento musical mais antigo que existe. Desde os primórdios, antes da invenção de flautas e tambores, os humanos já emitiam sons vocais, batiam palmas e pés no chão como forma de comunicação e linguagem, além de seu uso durante ritos e danças.

Entretanto, é importante conhecer um pouco sobre o surgimento da educação musical, além de buscar as origens do pensamento que propõe o uso do corpo como um instrumento neste processo de apropriação e aprendizado.

De acordo com Fonterrada (2008) a busca pela valorização da música tem origem na Grécia Antiga. Era dado uma importância imensa à música, pois todos precisavam dela para viver, afinal trazia benefícios éticos, morais, políticos e sociais, influenciando assim a formação de caráter e de cidadania.

Durante a Idade Média, o ensino musical estava intimamente ligado com a questão religiosa; a música era vista como uma ciência pelo Cristianismo.

Dentro do entendimento de música como louvor a Deus, e ao lado da visão teórica, constituindo-se a Igreja na grande disseminadora de conhecimento, $\mathrm{o}$ controle do aprendizado musical lhe é confiado e, embora ainda não se possa falar em "educação musical" na acepção que hoje se dá ao termo, a atividade prática de música com a presença de crianças é considerada um de seus pontos principais... Como o maior propósito da música era louvar a Deus, as instituições cristãs, isto é, as igrejas, conventos e seminários arregimentavam crianças dotadas de boa voz para suprir as necessidades de seus coros.

\footnotetext{
${ }^{4} \mathrm{O}$ roteiro de entrevistas, assim com a sua transcrição estão no Anexo da presente dissertação.
} 
Geralmente provindas de lares pobres, essas crianças garantiam, muitas vezes, o sustento próprio e o da família. (FONTERRADA, 2008, p.35)

Infelizmente este ensino não tinha um propósito educativo. As crianças tinham por função cantar nas missas e ofícios, e se apresentar para o alto clero e nobres. Era comum sofrerem maus tratos e muitas chegavam a morrer. $\mathrm{O}$ ensino musical para as crianças começou a mudar e receber a devida importância a partir do período renascentista.

No que se refere à educação, uma importante mudança se faz sentir a partir dessa época, com a aceitação da criança como ser que necessita de cuidados especiais, de saúde e lazer, afastando-se da maneira de entendimento vigente no período medieval, em que era considerada um tipo de animal de estimação, feita para divertir os adultos e conviver com eles. (FONTERRADA, 2008, p. 47)

A partir do Renascimento, a educação musical foi evoluindo gradativamente, embora ainda bastante ligada aos corais religiosos e, a partir dos séculos XVIII e XIX, à música de concerto da tradição européia.

Ainda de acordo com Fonterrada, Jean Jacques Rosseau foi o primeiro pensador que rompeu com este modelo de educação e apresentou uma pedagogia diferenciada, mais voltada ao desenvolvimento humano, em oposição às correntes filosóficas classicistas que permeavam o pensamento daquela época.

Jacques-Dalcroze, influenciado diretamente pelas ideias de Rosseau, foi o primeiro pesquisador a agregar o corpo como instrumento de aprendizagem musical.

"Dalcroze propôs um trabalho sistemático de educação musical, baseado no domínio do movimento corporal e na habilidade de escuta. Sua abordagem era totalmente nova para a época (..) A percepção da importância psicológica do movimento e sua relação com os aspectos afetivos e intelectuais levou Dalcroze a desenvolver seu Método de educação musical. Os instrumentos eram a voz cantada, o movimento corporal e o uso do espaço. Dalcroze procurava superar a dicotomia corpo-espírito, traço característico do século XIX, e propôs um ser humano integrado em si e consigo mesmo. Para isso, desejava atuar entre os conceitos de liberdade e estrutura. Em relação à estrutura, Dalcroze buscava aprofundar as habilidades dos alunos quanto à independência rítmica dos membros e das outras partes do corpo, e a sensibilidade de respostas físicas aos parâmetros musicais." (CINTRA, 2006, p. 71) 
Edgar Willems, aluno de Dalcroze, deu sequência aos estudos corporais de aprendizado, dando ênfase à relação entre a música e o ser humano, apesar de dar pouco espaço ao trabalho com o corpo. Zoltán Kodály, também contemporâneo de Dalcroze, destacava a importância das músicas tradicionais e folclóricas no aprendizado musical, salientando assim a criação de uma identidade cultural nos processos de aprendizagem. Carl Orff, além do desejo de propor uma reforma na educação musical, destacava também a importância dos movimentos corporais no desenvolvimento individual, emocional e musical do indivíduo, unindo o estudo da rítmica com a espacialidade corporal. Ele abriu mais espaço para o trabalho corporal, inserindo uma expressão corporal mais aberta.

O instrumento musical por excelência é o corpo humano inteiro, ele é mais capaz, do que qualquer outro, de interpretar os sons em todos os seus níveis de duração. (BACHMANN, 1998, p. 37)

Vale destacar a importância da utilização da improvisação nos estudos de Orff, desde os primeiros contatos com a música até a formação superior. $\mathrm{O}$ foco não está somente em um resultado final mas sim no caminho para se chegar até ele.

A noção de grupo é privilegiada em sua pedagogia; Orff utiliza recursos que
convidam o aluno a atuar como participante e como espectador, dando
liberdade para que cada um, à medida que desenvolve seu próprio potencial,
possa também contribuir para a evolução do grupo como um todo. Este
princípio se assemelha à estratégia de palco e plateia usada por Viola Spolin
em seu sistema de jogos teatrais. Essa atitude valoriza também o aluno
enquanto ouvinte, desenvolvendo a escuta e a reflexão crítica sobre ela.
Trata-se, portanto de uma concepção que traz a socialização do participante
para o primeiro plano. Outro ponto de contato do trabalho de Orff com
Spolin é a ideia de que o processo é mais importante que os resultados, de
maneira a permitir que cada indivíduo possa evoluir em seu ritmo
próprio. (CINTRA, 2006. 78)

Murray Schafer, compositor, escritor, ambientalista e educador musical canadense, se destacou por ter desenvolvido o conceito de paisagem sonora (soundscape) além de propor um estudo corporal não necessariamente rítmico, mas voltado à integração dos sentidos no fazer musical. Para ele o homem e o ambiente em que ele está são fatores fundamentais no fazer musical, um ajuda a compreender o outro. 
Como músico prático, considero que uma pessoa só consiga aprender a respeito de som, produzindo som, a respeito de música, fazendo música. Todas as nossas investigações sonoras devem ser testadas empiricamente, através dos sons produzidos por nós mesmos e do exame desses resultados. [...] Precisamos contar o que está disponível. Os sons produzidos podem ser sem refinamento, forma ou graça, mas eles são nossos. É feito um contato real com o som musical, e isso é mais vital para nós do que o mais perfeito e completo programa de audição que se possa imaginar. (SCHAFER, 1991, p.68)

A respeito do conceito de paisagem sonora proposto por Schafer, podemos aqui já estabelecer como um possível vínculo com o "Onde" dos jogos teatrais de Viola Spolin.

Todos estes colaboradores influenciaram na concepção e na criação da forma de ensino da percussão corporal do grupo Barbatuques. Eles ajudaram a abrir novos caminhos para uma educação musical que considera o corpo como ferramenta de aprendizado no processo da construção dos conhecimentos musicais. O grupo é citado por Carlos Eduardo de Souza Campos Grande, um professor de matemática que tem um estudo bastante interessante na relação entre esta disciplina escolar e a educação musical:

Nas atividades de montagem e ritmos ou coordenação motora prevalece o juízo perceptivo e a escuta intelectual. [..] É curioso notar que essa predisposição perceptiva varia de pessoa para pessoa. Para alguns, o caminho da percepção tácita, mais intuitivo, é o melhor para conseguir aprender um ritmo. Depois numa segunda etapa, viria a reflexão e o entendimento. Outros preferem um caminho mais racional, procurando entender todas as etapas de um ritmo antes de executá-lo, sendo assim necessário algum tipo de código ou convenção musical. [...] Geralmente, a pessoa que percebe a música pela via da intuição e da fruição costuma aprender mais rapidamente do que aquela que tem que pensar em todas as etapas antes de tocar. Por outro lado, a dimensão interpretativa é fundamental para o exercício consciente da linguagem musical. A riqueza do conhecimento musical está justamente na articulação entre a percepção intuitiva e a escuta consciente, entre a liberdade da criação e a disciplina da técnica, entre a razão e a emoção, entre o corporal e o intelectual. (GRANJA, 2006, p. 124-5)

François Delalande, compositor, pesquisador e musicólogo francês defende que as crianças organizam e reorganizam suas experiências e produções musicais autônomas (em

\footnotetext{
5 "Onde", "Quem" e "O Quê" são elementos que fazem parte do sistema de improvisação criado por Viola Spolin, educadora teatral norte-americana que criou uma metodologia de aprendizado cênico através de diversos jogos teatrais.
} 
relacão ao escutar, ao produzir, ao experimentar), de maneiras que convergem com o que diz Piaget em sua proposição das etapas de jogo (sensório-motor, simbólico e regras). Esta abordagem de Delalande estimula a observação da produção sonoro-musical das crianças partindo do que elas fazem para, então, intervir, ampliando as experiências de diversas maneiras. Delalande observa e escuta o que as crianças produzem de modo autônomo e propõe uma pedagogia que, a partir deste lugar, estimule e favoreça a ampliação e a transformação das experiências. Ingrid Koudela também faz um paralelo bem interessante deste assunto com o universo cênico em seu livro "Jogos Teatrais".

\section{Teatro e treinamento musical}

A ideia de uma interdisciplinaridade entre Teatro e Música tem se mostrado cada vez mais relevante. $\mathrm{O}$ artista teatral precisa expandir suas possibilidades, desenvolver e ampliar o seu repertório para se apropriar de ferramentas que estarão à sua disposição no seu fazer artístico.

Diversos autores e pesquisadores teatrais têm relatado em suas obras a importância do treinamento da movimentação corporal no trabalho do ator, sugerindo uma formação teatral que promova a criação e a expressão. Podemos com isso sugerir a musicalização como uma poderosa ferramenta de ampliar estas possibilidades.

O artista teatral precisa ter em sua formação, um mínimo de conhecimento musical. Mesmo não sendo um músico instrumentista, ele precisar entender alguns parâmetros sonoros que fazem parte de uma obra artística e teatral: timbre, intensidade, duração, altura, densidade, noção temporal, pulso, ritmo, entre tantos outros. Claro que o artista teatral, na ausência de um aprendizado musical mais consistente e profundo, poderia saber estes conceitos de uma forma mais intuitiva mas, sendo um estudante em formação, tem como obrigação estudar e se dedicar para poder ter uma maior consciência de seus propósitos e possibilidades artísticas.

Por outro lado podemos notar um certo despreparo de muitas escolas de teatro ao lidar com a questão da educação musical. A deficiência ou ausência de um ensino musical mais aprofundado ainda é uma constante em muitas escolas de teatro do Brasil. Geralmente associam o ensino musical apenas com aulas de canto ou sapateado e muito raramente trabalham com instrumentos musicais devido à dificuldade orçamentária de ter em seus acervos instrumentos em variedade, quantidade e qualidade, de acordo com o número de 
alunos. Outro ponto é a grade curricular. Diante de tantas possibilidades de outros conteúdos possíveis, por que abrir espaço para o desenvolvimento musical? Deixar o aluno correr atrás de uma aula particular de música? Seria responsabilidade da escola formar musicalmente este aluno? O uso da música corporal e dos jogos musicais poderia responder em parte estas questões. Seu uso poderia ser feito dentro das aulas de teatro como aquecimento inicial, por exemplo. Se alguns momentos das diversas aulas forem dedicados à questão educativa musical, com o passar do tempo, seriam horas e horas de estudo e treinamento musical, colaborando de forma significativa com a musicalização dos alunos. Hoje em dia, com a recente abertura e expansão do mercado de espetáculos musicais, as escolas de formação especializadas neste setor têm se mostrado mais abertas em relação às questões educacionais musicais, objetivando seu foco de ensino nesta formação específica. Estes atores formados terão logicamente uma bagagem musical bem mais aprofundada, podendo utilizar esses conhecimentos a seu favor em outros gêneros teatrais. Carlos Bauzys, criador da disciplina "Percussão Corporal" no curso de formação em Teatro Musical do SESI -SP argumenta durante sua entrevista para esta dissertação sobre este assunto:

$\mathrm{Eu}$ enxergo muito a percussão corporal como instrumento forte de musicalização para o ator também conhecer mais do seu próprio corpo. Desenvolver essa noção rítmica e como instrumento para eu poder aplicar a teoria musical na prática, no próprio corpo. Para os atores entenderem por exemplo, as subdivisões musicais que eles estão aprendendo na aula de teoria. Colcheia, semicolcheia, semínima e aplicar no corpo. Fora isso, a percussão corporal, que na prática que a gente sempre fez no Barbatuques e no grupo de estudos, sempre trouxe muito lado da improvisação, da improvisação musical. Com os elementos que você tem musicalmente utilizando o próprio corpo, improvisar em grupo sempre foi uma prática muito valiosa para as pessoas irem soltando a própria musicalidade. Começarem a entender que eles são artistas criadores de música inclusive, e quando você está criando em conjunto, você desenvolve essa percepção de que você precisa estar sempre conectado, sempre ouvindo tudo que está seu redor para você poder criar algo coerente com tudo aquilo e isso vai te dando, vai criando ferramentas incríveis para o ator. Vai realmente desenvolvendo um outro lado da mente que eu enxergo de primordial importância, tanto no quesito de improvisação, de criação quanto de percepção. Então, por todos esses motivos que a percussão corporal faz parte do curso teatro musical e agora com uma turma já formada, eu percebo que foi um acerto, realmente faz muita diferença, é uma ferramenta valiosíssima. (Entrevista concedida por Carlos Bauzys, julho de 2018) 
$\mathrm{O}$ artista teatral deveria aprender a tocar pelo menos um intrumento musical. Entretanto, a maioria das escola de teatro do Brasil infelizmente não possui estrutura e nem o propósito de ensinar a tocar instrumentos devido à uma questão logística e muitas vezes, ideológica. É comum a suposição de que música se aprende unicamente em escolas especializadas e conservatórios. Portanto, caberia ao aluno a responsabilidade de procurar este estudo fora da escola de teatro, nas escolas de música, ou mesmo na Internet: hoje em dia é possível encontrar gratuitamente diversos vídeos educativos ensinando a tocar os mais variados instrumentos. Neste caso, seria possível aprender a tocar (ao menos rudimentarmente) um instrumento de modo autodidata; mas para entender o funcionamento do jogo musical é necessário estar em grupo. Apenas deste modo será possível vivenciar e perceber sutilezas que vão além de simplesmente saber tocar um instrumento ou dizer um texto solitariamente. Para aprofundar nestes estudos, é necessário escutar e perceber do outro. Os jogos que envolvem duas ou mais pessoas auxiliam nestas descobertas.

As comunidades de jogadores geralmente tendem a tornar-se permanentes, mesmo depois de acabado o jogo. É claro que nem todos os jogos de bola de gude, ou de bridge, levam à fundação de um clube. Mas a sensação de estar "separadamente juntos", numa situação excepcional, de partilhar algo importante, afastando-se do resto do mundo e recusando as normas habituais, conserva sua magia para além da duração de cada jogo (...). $\mathrm{O}$ caráter especial e excepcional do jogo é ilustrado de maneira flagrante pelo ar de mistério em que frequentemente se envolve por se fazer dele um segredo. Isto é, para nós, e não para os outros. O que os outros fazem "lá fora" é coisa que no momento não nos importa. Dentro do círculo do jogo, as leis e costumes da vida cotidiana perdem validade. Somos diferentes e fazemos coisas diferentes. (HUIZINGA, 2014, p. 15)

Deste modo, os jogos de percussão corporal podem ajudar a suprir esta necessidade de estabelecer este estado de jogo coletivo.

\section{Barbatuques e treinamento musical para atores}

Nesta encruzilhada, o ensino da percussão corporal e jogos musicais na educação musical do artista teatral surge como um poderoso aliado, com o propósito de ajudar a otimizar e colaborar positivamente para esta questão.

Vale lembrar que este estudo, no trabalho do artista teatral, acaba tomando dimensões muito maiores do que somente o aprendizado musical. $\mathrm{O}$ ator, na arte da 
interpretação, usa seu corpo como instrumento de trabalho. Ao utilizar seu próprio corpo também como instrumento musical, existe quase que instantaneamente uma identificação de linguagens. Todos conhecem alguém que foi traumatizado musicalmente pela famigerada professora de piano ou aquela pessoa que jura para si mesma que não tem ritmo e nunca terá. Ao ter contato com os jogos musicais corporais, todas estas questões ficam em segundo plano. A empatia lúdica e a facilidade dos jogos propostos cativam de tal forma o ator-jogador que muitas vezes, sem ter a consciência, ele já estará fazendo música.

Os jogos musicais e a percussão corporal podem proporcionar ao estudante de teatro uma sensibilização musical que pode refletir sobre outras áreas, como sua expressividade e desenvoltura corporal, além de expandir sua criatividade e capacidade de escuta, atenção e de jogo.

A percussão corporal e os jogos musicais corporais podem ajudar a preencher uma lacuna na formação do artista teatral, especialmente neste país tão reconhecido mundialmente pela força que sua música traz. Precisamos trazer esta força musical para dentro das salas de aula de teatro, não apenas do modo tradicional que vem sendo trazido mas abrindo novas possibilidades e horizontes.

Vale ressaltar que um ensino musical mais completo precisaria de uma série de atividades, tais como rítmica, canto, solfejo, escrita musical, aprendizagem de um instrumento, história da música, técnica vocal, fonética, fisiologia da voz, harmonia, entre muitas outras. Entretanto, ainda existe uma tendência muito tradicionalista nesta forma de aprendizado musical. É preciso trabalhar estas atividades de outras maneiras, abordando outras características pedagógicas. Esta dissertação pretende colaborar propondo possíveis olhares sobre estas possibilidades. 


\section{CAPÍTULO II - O CORPO MUSICAL}

\section{O grupo Barbatuques}

Diferentemente de outros grupos que usam a percussão corporal como um recurso sonoro extra, o Barbatuques faz dessa linguagem o centro de gravidade de sua música. (GRANJA, 2010, p. 118)

O grupo, criado em 1997 pelo músico Fernando Barba, nasceu de maneira lúdica e espontânea. Desde pequeno, Fernando gostava de reunir os amigos, nos horários de recreio, na escola, para fazer rodas de batucadas corporais e jogos de improvisação musical. Ensinava sons corporais, sugeria encadeamentos de percussões e cantos, sempre utilizando apenas o corpo como instrumento. Foi na UNICAMP, fazendo o curso de bacharelado em Música, que Fernando começou a aprofundar cada vez mais seus estudos na percussão corporal, influenciado, principalmente, pelo trabalho de rítmica do professor José Eduardo Gramani, além de ter contato com as pedagogias musicais propostas por Emile Jaques-Dalcroze, Carl Orff, Theophil Maier, Murray Schafer e Hans Joachin Koellreutter.

Ao se formar, Fernando Barba e outros dois colegas de faculdade, André Hosoi, integrante do grupo até hoje, e Marcos Azambuja, fundaram uma escola de música na cidade de São Paulo chamada Auê Núcleo Musical. Além dos cursos convencionais, Barba resolveu, a pedido de amigos e entusiastas, abrir um curso chamado Rítmica Corporal. De acordo com João Simão:

Nesse primeiro ensaio do curso de rítmica corporal, Barba foi experimentando e delineando uma maneira de ensinar percussão corporal. Alguns conhecimentos que já haviam sido acumulados estavam sendo postos em prática. (SIMÃO, 2013, p. 19)

O encontro de Fernando Barba com o músico Stenio Mendes foi transformador para o desenvolvimento de sua pesquisa de percussão coporal.

Stenio trazia, em sua bagagem, o conceito de música espontânea ${ }^{6}$, trabalhando com diversos jogos de escuta, improvisação e pesquisa de timbres, principalmente vocais. Um dos

\footnotetext{
${ }^{6} \mathrm{O}$ termo "música espontânea" não possui um registro acadêmico que o conceitue. Stenio Mendes refere-se a ele em suas oficinas. Caracteriza-se como uma atividade de criação performática como consequência e um desdobramento que começa pela busca de novos timbres e novas estéticas vocais e percussivas. (DI LUCA, 2011, p. 48)
} 
grandes inspiradores do estudo musical de Stenio foi Theophill Maier ${ }^{7}$, que possuía uma pesquisa sobre as possibilidades fonéticas da voz e ruídos orgânicos vocais.

A atividade da "música corporal", pode ressignificar o corpo, primeiro como um tambor, batendo, estalando, esfregando, intensificando consideravelmente, a "presença" do artista. Música corporal vista como um fazer musical, sons da própria pele e os sons fonéticos também serão poetizados, destacando seus aspectos melódicos principalmente nas vogais, e percussivos na consoantes. É perceber, discernir, harmonizar com a coerência, melodias, timbres, batendo, estalando, esfregando, em toda a extensão do corpo, nas suas diferentes densidades musculares, na dança rítmica no movimentos de ósseos articulados, dialogando com as paredes ocas e graves, sobre o peito, abdômen, marcando nas pernas, pés o nosso chão, o passo, o pulso. O coração, respiração que se integram aos estalos dos dedos, dividindo em preciosos segundos em semínimas e o grito primordial, nas cordas ressoantes, pregas laríngeas, consoantes percussivas, vogais melódicas, desliza plosiva, oclusa no céu da boca a língua entre palatos, dentes e lábios, é um instrumento extraordinário. Para o artista a experiência de usar o corpo como se fosse um instrumento musical, leva a um deslocamento do sentido habitual deste corpo, para o olhar de contemplação, de distanciamento. O nosso eu-consciência se separa do objeto-corpo e pode observar o corpo orgânico como um novo instrumento musical, assim como o ator também desloca e cria uma separação psicológica de seu corpo habitual, para a entrega, a se deixar possuir por outra persona, com outros hábitos. Este estado de distanciamento e de contemplação se desdobra aqui como um estado de luz, de "presença", uma atenção limpa de qualquer dispersão, que vai qualificar o artista no seu grau de clareza de percepçãoatuação. (Entrevista concedida por Stenio Mendes, julho de 2018)

Foi Theophil que apresentou, para ele, os três pilares fundamentais do jogo musical de improvisação: ouvir o outro, sentir o outro e manter o outro. Mais adiante, no capítulo de jogos musicais da presente dissertação, esta abordagem será aprofundada.

Com a fusão do trabalho de Stenio (com seus sons mais abertos e orgânicos, sua busca por novos timbres e seus jogos musicais), Barba (suas atividades rítmicas e combinatórias dos sons e outros jogos musicais) potencializou a transformação e a complexidade do trabalho do Barbatuques. (SIMÃO, 2013, p. 20)

\footnotetext{
${ }^{7}$ Theophill Maier, alemão, ator, cineasta, integrante do grupo performático Trio ExVOCO e intérprete contemporâneo de John Cage.
} 


\section{O Núcleo Educacional}

No grupo Barbatuques, o lado artístico e pedagógico sempre caminharam juntos, nutrindo e inspirando um ao outro. Analisando a origem desta manifestação, Fernando Barba apresentava e ensinava, para os seus colegas de escola, frases rítmicas musicais que criava utilizando seu próprio corpo, demonstrando assim que, além da apresentação artística, o caráter educacional e pedagógico sempre esteve presente. Até os dias de hoje, o grupo possui estas duas vertentes: se apresenta em shows, eventos, gravações, produz trilhas musicais para cinema, tv, teatro, publicidade e paralelamente, ministra oficinas e workshops para os mais diversos públicos.

No início, as oficinas eram ministradas somente pelo Barba mas, com o passar do tempo, esta demanda começou a aumentar. Como todos os integrantes do grupo artístico já possuíam uma grande experiência sobre os conteúdos das oficinas, pelo convívio e tempo de pesquisa, também começaram ter autonomia para conduzi-las.

Desde a primeira aula de percussão corporal na escola Auê, Fernando Barba criou uma metodologia a ser aplicada em um grupo de estudos. Mesmo com alguns registros escritos, como apostilas ${ }^{8}$ e entrevistas, neste primeiro momento a pesquisa foi voltada, principalmente, para a parte prática: o fazer musical. Do mesmo modo que em diversas manifestações da cultura popular os conhecimentos são transmitidos oralmente, o saber produzido no grupo musical e nas oficinas de percussão corporal ministradas por Fernando Barba era memorizado, não possuindo um registro escrito mais aprofundado, mesmo estando em uma escola de música. A primeira peça de percussão corporal criada por ele, chamada "Barbapapa's Groove" foi, durante muitos anos, ensinada de modo prático, através da memorização de movimentos. Somente anos mais tarde é que o músico e diretor musical Carlos Bauzys a transcreveu para partitura.

De certa forma, este ensino realizado através da prática foi bastante significativo em relação a um estudo musical diferente e inovador. Indo na contramão de muitos métodos musicais que propõem um início da aprendizagem a partir de uma partitura, os jogos de musicalização corporal criam uma empatia lúdica de imediato naqueles que os praticam, justamente porque é possível fazer música por um viés mais prazeroso. Aprender música fazendo música. E as oficinas ministradas pelo grupo começaram a ser reconhecidas justamente por esta característica. Importante ressaltar que, mesmo sendo prática, toda a

\footnotetext{
${ }^{8}$ André Hosoi foi um grande colaborador da escrita musical, além de ilustrador.
} 
pesquisa sempre esteve respaldada nos educadores musicais e pensadores teóricos que influenciaram a trajetória educacional do grupo.

Entretanto, um grande repertório de conhecimento começou a ser criado e acumulado. Diversos jogos, exercícios, peças musicais eram compartilhados e memorizados, mas foi-se percebendo a necessidade de existir um registro destas atividades. As pessoas que faziam as oficinas, especialmente professores, arte-educadores, regentes de coral, entre outros, começaram a pedir para o grupo disponibilizar materiais escritos, pois gostariam de levar estes conhecimentos para compartilhar em outros lugares, como grupos artísticos, escolas, ongs, etc..

Em 2009, Fernando Barba, André Hosoi e Stenio Mendes começaram a se reunir regularmente para produzir um livro sobre a metodologia de uma educação musical através do corpo. Na sequência, outros integrantes do grupo artístico, que já ministravam oficinas e tinham interesse em aprofundar estes assuntos, começaram a frequentar estas reuniões para colaborar com as discussões e reflexões. A partir do momento que começaram a ocorrer estes encontros fora dos horários de ensaio do grupo artístico, o Núcleo Educacional foi consolidado.

Uma das maiores virtudes percebida pelo Núcleo diz respeito à pluralidade da pesquisa. A percussão corporal não precisa servir apenas para os músicos mas, também, pode ser inserida em outros contextos e públicos com os mais diversos propósitos. Professores de disciplinas escolares, de educação física, empresários, bailarinos, atores, psicólogos, médicos, portadores de necessidades especiais, etc.. É possível, através das oficinas, desenvolver diversos objetivos, como integração, lazer, desenvolvimento de relações, aprimoramento artísticos entre outros.

Como faço parte do grupo, esta dissertação vislumbra se transformar posteriormente em uma publicação, colaborando assim com um dos grandes propósitos do Núcleo, que é o registro e produção de material instrutivo.

\section{O Núcleo Artístico}

No início, não existia a pretensão de formar um grupo para apresentações em shows. O primeiro convite aconteceu através do músico Luis Gayotto que, na época, era integrante da oficina de rítmica ministrada pelo Fernando Barba. Neste show, o grupo participou de duas músicas e foi um grande sucesso. Aquela curiosa técnica inovadora de fazer música no 
próprio corpo causava grande empatia no público. Os convites para se apresentar foram aumentando enquanto o Barba criava as primeiras composições.

Com o passar dos anos, o grupo evoluiu, participando, cada vez mais, de shows pelo Brasil e pelo mundo. Gravou quatro CDs e dois DVDs, além de participar em trilhas sonoras de diversos filmes e publicidades. Também foi fonte inspiradora para a criação de diversos grupos artísticos e educacionais.

Durante esta contínua jornada, muitos grupos se contaminaram em níveis diferentes, pela pesquisa do Barbatuques. O NOP (Núcleo Orgânico Performático), que se originou, a partir das oficinas ministradas por Stenio Mendes e Fernando Barba na ULM (Universidade Livre de Música) Tom Jobim, em São Paulo, é um exemplo de grupo artístico que teve como ponto de partida a pesquisa do Barbatuques, ainda no início de seu desenvolvimento. Outro exemplo é o Grupo Fritos, grupo de estudos de música corporal, originalmente criado por Fernando Barba, em 2003, na escola de música Auê Núcleo Musical, em São Paulo. Passou por muitas transformações e, apesar de tantas mudanças na organização e na coordenação, permanece, até hoje, com estudos semanais regulares, promovendo, também, outras atividades, como a Fritura Livre, um encontro aberto e gratuito que propõe dinâmicas de música corporal em praças e espaços públicos. Além destes, outros projetos também se nutriram a partir da pesquisa do Barbatuques, desdobrando-se em grupos artísticos, grupos de estudos e projetos sociais, como, por exemplo, Batucantantes (SP) e Tiquequê (SP), destinados ao público inafantil, Karallargá (SP), Stallo (CE) e Wanamusiki (MT), grupos musicais, Batucadeiros (DF), TucBoys (SP), Música Para Todos (SC) e Embatucadores (SP), vinculados a projetos sociais, Batukatu (RS) e Grupo de Estudos do Barba (SP), grupo de estudos de música corporal. (CONSORTE, 2014, p. 40)

Podemos ainda acresentar o grupo Badulaque (SP) e Bande Música Corporal (Uruguay).

\section{A pesquisa e o encontro com a academia}

A pesquisa pedagógica realizada pelos Barbatuques já foi amplamente citada nas mídias e também em artigos, revistas especializadas, livros e apostilas didáticas. A técnica desenvolvida pelo grupo também começou a ser utilizada, cada vez mais, nas aulas de música, nas escolas brasileiras - tanto particulares quanto públicas - e ganhou força entre os educadores pela facilidade de aplicação, inovação, simplicidade e baixo custo para as instituições, pois não é necessário ter instrumentos musicais. Apenas uma sala de aula com as 
cadeiras afastadas já é suficiente para se ter um aprendizado musical concreto, lúdico e bastante rico em conteúdos.

Entretanto podemos considerar que o tema "percussão corporal" ainda está dando seus primeiros passos dentro do universo acadêmico. Por se tratar de um assunto relativamente novo, existem poucas, mas significativas, citações em publicações, artigos, monografias, dissertações e teses. Algumas estão presentes nas referências bibliográficas desta dissertação. Entretanto, ainda existe uma carência de literaturas específicas mais aprofundadas sobre o assunto, sobretudo no que diz respeito à intersecção destes estudos com o âmbito teatral, tema deste mestrado.

Podemos citar, como um dos precursores desta linguagem, o pesquisador Alexandre Cintra Leite Rüger (2007), que apresentou uma relevante dissertação a respeito da percussão corporal na sensibilização musical de atores e estudantes de teatro. João Paulo Simão (2013), integrante do grupo Barbatuques, apresentou um mestrado sobre o grupo, abordando um estudo dos processos de ensino da percussão corporal do grupo Barbatuques. Outros pesquisadores acadêmicos que aprofundaram e colaboraram com a questão dos estudos da percussão corporal foi Thiago di Luca (2011), Vinícius Burlamaque Feder (2011), Larissa Finocchiaro Romualdo da Silva (2014), Pedro Leme Consorte (2014), Mariana Gomes Mazieiro (2016), Roberto Ricardo Santos de Amorim (2016) e Roberta Forte (2018), todos presentes nas referências bibliográficas da presente dissertação de mestrado.

\section{Os Três Centros Sonoros}

Para aprender a tocar qualquer instrumento musical, é preciso, antes de tudo, conhecê-lo. Saber do que é feito, conhecer suas origens, seu funcionamento, aprender como se toca. Respeitar seus limites, estudar suas possibilidades e cuidar deste instrumento, tomando os devidos cuidados. Tratá-lo com zelo, carinho e, principalmente, amor e respeito. Se isto se aplica aos instrumentos convencionais, havemos de convir que estas orientações tomam proporções muito maiores quando o instrumento musical é o próprio corpo humano. 
Figura 1: O Homem Vitruviano

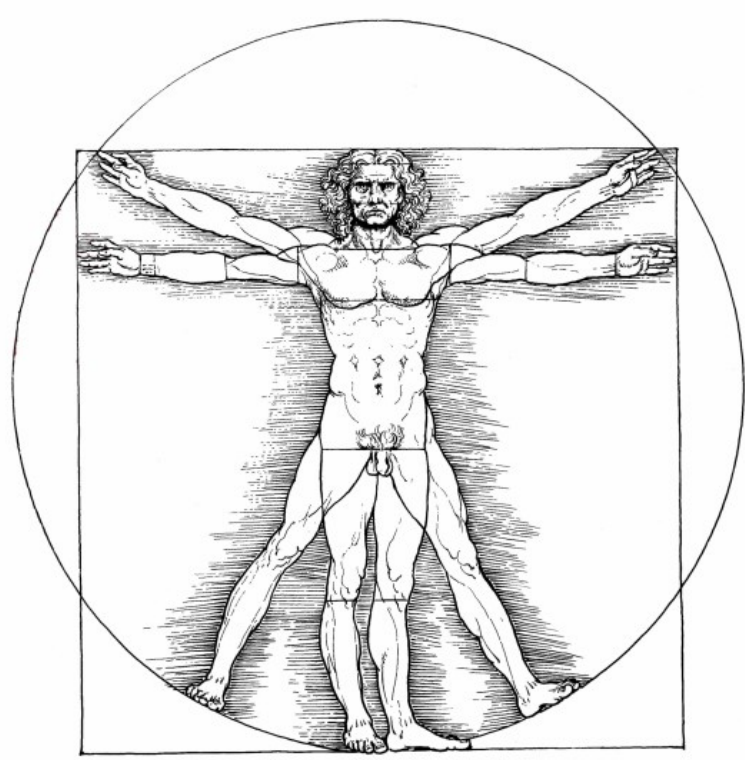

Fonte: Wikipedia

Acima segue uma representação do nosso instrumento de pesquisa. O famoso desenho intitulado "O Homem Vitruviano", produzido em 1490 por Leonardo da Vinci pode ser utilizado para ilustrar o corpo, nosso instrumento musical de estudo nesta presente dissertação. No estudo da música orgânica e da percussão corporal, utilizamos as cinco extremidades do corpo humano para produzir sons: os dois pés, as duas mãos e a boca (representada pela cabeça). Com isso temos três partes distintas que podem ser chamadas, individualmente, de "Centro Sonoro Corporal", onde cada um delas apresenta diversos timbres e sonoridades.

Em relação às possibilidades de sons corporais em cada Centro Sonoro, podemos notar uma curiosidade matemática:

\footnotetext{
${ }^{9}$ Com esta figura, Da Vinci exalta o Renascimento italiano em todas as suas formas. Nesta "Divina Proporção", o umbigo estará sempre no centro do círculo. O homem está em perfeito equilíbrio com a natureza, relacionandose, assim, diretamente com todas as formas do universo, e vice-versa. Este desenho nos mostra que o corpo humano possui múltiplas proporções matemáticas que podem ser expressadas geometricamente. Podemos notar na gravura que as formas do corpo estão equilibradas em relação às figuras geométricas, o círculo e o quadrado, simultaneamente.
} 
Centros Sonoros - Possibilidades Sonoras e Diversidade de Timbres (gráfico ilustrativo)

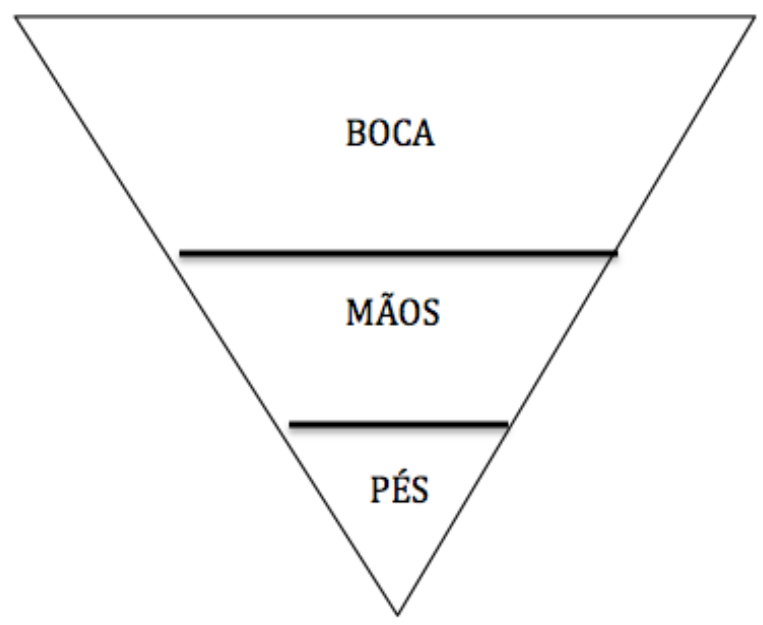

Estalos de língua, vácuos, vibratos, sopros, assobios, vozes, cantos

Palmas, estalos, mãos no corpo, mãos na boca

Pisadas, sapateados

Fonte: O próprio autor.

Nos três centros sonoros, existe uma progressão em relação à quantidade de sons que o corpo humano pode produzir. A diversidade sonora que os pés podem executar é menor do que as possibilidades que mãos produzem. Estas, por sua vez, são ainda menores que a numerosidade de sons feitos pela boca.

A pesquisa da música corporal e dos jogos de percussão corporal utiliza, pelo menos, um destes Centros Sonoros, obrigatoriamente. Podemos também estabelecer uma relação direta dos três Centros com os diversos estudos de movimento corporal do artista cênico. "Os movimentos do corpo podem ser sumariamente divididos em: passos, gestos dos braços e das mãos, e expressões faciais" (LABAN 1978, p. 46). É possível notar que estes movimentos estão ligados diretamente com as regiões sonoras aqui apresentadas.

Nesta pesquisa não podemos deixar de mencionar os sons relacionados à fisiologia humana, como espirros, tosses, batidas do coração, sons das vísceras, além dos reproduzidos pelos aparelhos excretores. Interessante perceber que a grande maioria destas sonoridades está relacionada aos órgãos internos situados no tronco do corpo, e não nas suas extremidades ${ }^{10}$, que é o objeto deste estudo. Estes sons já foram explorados em diversas performances e outras

\footnotetext{
${ }^{10}$ Neste conceito, podemos dizer que a boca faz parte da cabeça, que pode ser considerada também uma das extremidades corporais. Vide figura 1.
} 
manifestações artísticas; entretanto, na presente dissertação, serão abordadas apenas os sons relacionados aos três Centro Sonoros.

\section{Sons corporais e o gesto teatral}

Todo som precisa de algo que o produza, ou seja, ao vibrar, podemos afirmar que o som é movimento. Neste sentido, o som resultante destes movimentos vibratórios acaba estimulando outros movimentos.

Algumas sonoridades produzidas pelo corpo humano, dependendo do ambiente, país ou cultura em que estão inseridas, podem possuir um significado que vai além do meramente sonoro. É o caso, por exemplo, do som do estalo de dedos. Podemos utilizar tanto para chamar um garçom como para se referir ao termo "faz tempo". É comum também observarmos um diretor teatral estalar os dedos para o elenco ao comunicar que "está faltando ritmo na cena". Neste contexto, esta ação se transforma em um gesto, em uma forma de comunicação.

Pavis diz que constuma-se distiguir o gesto teatral de três formas distintas: gestos inatos, estéticos e "gestos convencionais que expressam uma mensagem compreendida pelo emissor e pelo receptor" (PAVIS, 2008, p. 185). Neste sentido, o código emitido é entendido por aquele que o recebe. Podemos então, dependendo do contexto, definir tais sons corporais como gesto teatral.

Diversas sonoridades feitas pelo corpo têm esta característica, de ter um significado concreto para quem ouve. Alguns exemplos brasileiros: o som da ponta da língua feita em sinal de reprovação; o som de pedir silêncio (chiiiiiuuuu); aplaudir alguém durante sua fala; o estalo chicote de dedo feito repetidamente com uma mão (que pode significar "corre", "saiu de pinote", "lascou”), a palma alternada de costas de dedo (que significa "tanto faz"). Alguns sons podem ser considerados ofensivos, como o assobio "fiu fiuuu", a palma copinho, entre outros.

Por outro lado, é importante perceber que cada gesto praticado pelo ator em cena também pode ter um sentido musical. Ao levantar a mão, por exemplo, existe um ritmo, uma velocidade e uma intensidade que pode ser entendida musicalmente. Todo gesto pode ser transformado em linguagem sonora, desde que o ator esteja consciente disto. 
Vale lembrar que todo som é a reação de uma ação. Não existe som sem existir algo que o provoque, ou seja, para existir um som, precisa existir um movimento. Neste sentido, podemos então afirmar que todo movimento resulta em uma sonoridade, mesmo que esta seja inaudível para os nossos ouvidos. Podemos classificar de modo musical todos tipos de movimento que existem no universo. $\mathrm{O}$ ator, ao ter consciência disso, torna-se um poderoso criador sonoro, através dos seus movimentos. Já estará praticando música, antes mesmo de entrar em cena, seja simplesmente respirando, caminhando ou até mesmo dormindo. Descobrir esta capacidade o faz tornar músico de si próprio.

\section{Centro Sonoro dos Pés}

Por seu caráter natural e intrínseco ao movimento de locomoção, o som dos pés pode ser considerado como um dos mais primitivos feito pelo ser humano. Podemos observar a sua existência inclusive nos animais que utilizam patas, dos insetos aos grande mamíferos.

Este som, pensado de forma musical, existe nos mais diversos povos e manifestações culturais. Pode ser feito de diversos modos, tanto com o pé inteiro no chão, ou parte dele ou com calçados, como botas, sapatos, tamancos, entre outros.

Alguns indígenas, como os Kariri-Xokos de Alagoas, tem o hábito de bater fortemente os pés descalços, no chão, em seus rituais e pajelanças, produzindo um som impressionantemente alto. Existem outras formas de sapateados, como por exemplo o tap dance americano, que é um estilo de sapateado estadunidense amplamente difundido através do cinema clássico e dos musicais da Broadway. O sapateadores utilizam um calçado especial que possui algumas chapas de metal em seu solado (podendo utilizar até moedas grudadas), criando assim sons característicos em cada parte do pé, especialmente nas pontas, debaixo dos dedos e no calcanhar.

Podemos também citar o Flamenco na Espanha, o Coco no Nordeste, com os seus tamancos de madeira ou a Catira, manifestação cultural de diversas regiões do interior do Brasil, que utiliza pesadas botas para marcar suas danças.

Temos também, como exemplo, o Gumboots, manifestação cultural criada pelos mineradores de ouro e diamantes na África do Sul. Como eram obrigados a utilizar, em seus trabalhos, botas de borracha cano alto, elaboraram uma espécie de dança musical bastante rítmica, inspirada em danças tradicionais africanas. A técnica de Gumboot consiste em 
intercalar palmas e sapateados com o som das mão, percutindo vigorosamente as laterais e outras partes das botas.

O Barbatuques utiliza, principalmente, a técnica de bater com a sola inteira do pé no chão. O timbre desta sonoridade pode variar de acordo com tipo de chão e calçado utilizado. Geralmente provoca um som grave, normalmente representado pela onomatopeia "Tum".

\section{Centro Sonoro das Mãos}

\section{KROTOS}

De acordo com a mitologia grega, Krotos, filho de Pan e Eufeme, tinha convívio com as Musas no Helicon, pois elas haviam sido amamentadas por sua mãe. Além de ser amante das artes, Krotos também era um exímio caçador e foi considerado o criador do arco e flecha. Também ficou conhecido como sendo o inventor do aplauso e do bater palmas para acompanhar uma música. Isto se deu devido à sua delicadeza e amabilidade em bater palmas para acompanhar e exaltar o canto das Musas, suas irmãs-de-leite e deusas da arte e da ciência. Em sinal de reverência, estas pediram a Zeus que o colocasse entre as estrelas, surgindo assim a constelação de Sagitário. Krotos também significa aplausos e som de palmas no idioma grego.

Bater palmas é a forma mais comum de produzir um som forte com o corpo, sem a necessidade de utilizar a voz. Esta manifestação existe em todas as culturas e pode ser considerada inerente à natureza humana, seja para acompanhar uma música, aplaudir ou para estabelecer alguma forma de comunicação.

Existem diversos timbres possíveis de serem produzidos com as palmas. É importante reconhecer que cada corpo tem sua própria característica. Diversos fatores podem influenciar na sonoridade, tais como o tamanho da mão, formato e modo de posicionamento dos dedos e centro das mãos.

É possível fazer uma escala de palmas, da mais grave à mais aguda.

\section{PALMA GRAVE}

Para fazer esta palma, as mãos devem ficar um pouco curvadas, como se fosse uma letra "C", com todos os dedos unidos, exceto o polegar. Encaixamos uma mão na outra, entrelaçando os polegares. 
Figura 2: Palma grave

palma grave

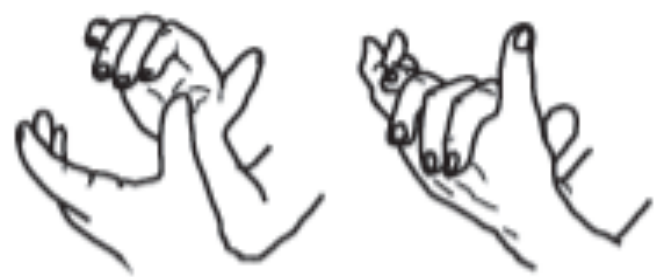

Fonte: Apostila Barbatuques

É o som mais grave que podemos fazer com as palmas. Interessante perceber que podemos fazer esta palma "ao contrário", simplesmente invertendo as mãos no momento de encaixar e entrelaçar os polegares.

\section{PALMA ESTRELA}

O nome desta palma é devido ao formato de mão aberta e dedos espaçados. Esticamos todos os dedos da mão, deixando eles bem abertos e espaçados entre si.

Figura 3: Palma estrela

\section{palma estrela}
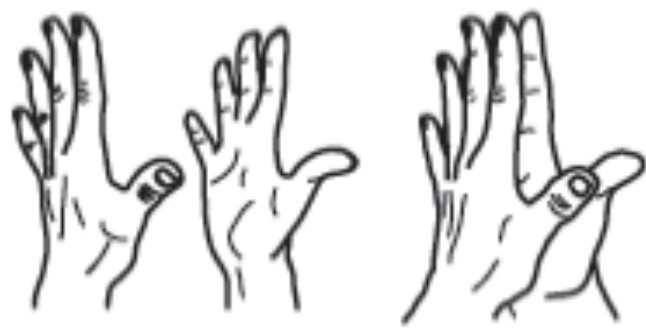

Fonte: Apostila Barbatuques

É preciso ficar atento para não deixar a mão tensa demais, evitando que ela fique curvada para o lado de fora. Importante deixar um pequeno vão entre as palmas. Bater de modo firme, evitando que as mãos se afastem logo após a palma ser feita. O som emitido é 
um som de altura média ${ }^{11}$ média, sendo possível escutarmos, de maneira definida, uma nota musical.

\section{PALMA ESTALADA}

Uma das palmas mais utilizadas, geralmente, pelas pessoas ao aplaudir, cantar "parabéns a você", chamar o vizinho, etc. Batemos os dedos de uma mão bem no meio da outra mão, gerando assim um som forte e agudo.

Figura 4: Palma estalada

\section{palma estalada}
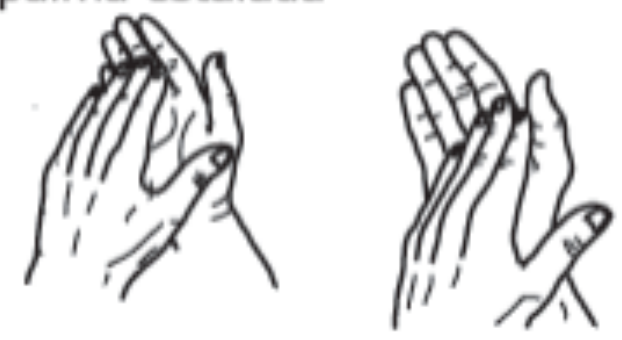

Fonte: Apostila Barbatuques

Esta palma também pode ser feita "ao contrário", ao inverter a função de cada mão.

\section{PALMA COSTAS DE MÃO}

Fechamos uma mão e batemos com as "costas" duma na palma da outra, gerando um som bem agudo.

Figura 5: Palma costas de mão

\section{palma costas de mão}
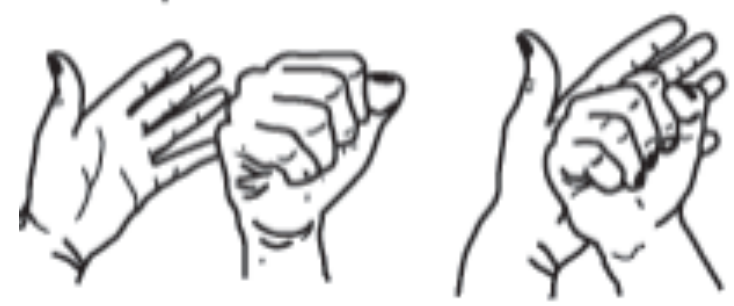

Fonte: Apostila Barbatuques

\footnotetext{
${ }^{11}$ Altura no sentido de grave e agudo, não de volume.
} 
Também é possível ser feita "ao contrário". Entretanto, como a pele da parte de cima das mãos é mais delicada, evita-se bater com muita força.

\section{PALMA PINGO}

Deixamos uma mão aberta, com a palma bem esticadas enquanto batemos com a outra, utilizando apenas dois dedos. Esta é a mais aguda das palmas.

Figura 6: Palma pingo

palma pingo
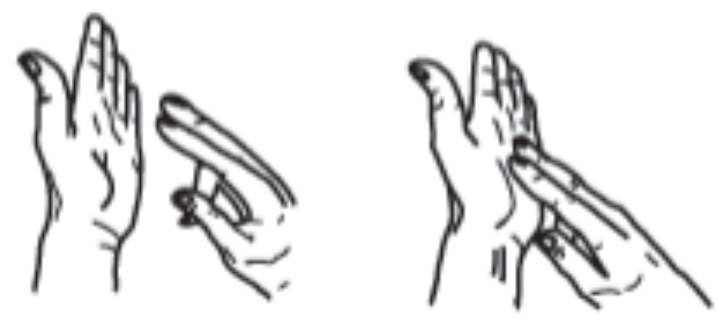

Fonte: Apostila Barbatuques

Segundo os princípios da física, quanto maior for o instrumento musical, mais grave será sua sonoridade e quanto menor, mais aguda. Podemos observar este fenômeno nos exemplos acima. Quanto menor a superfície de contato entre uma mão e outra, mais agudo se torna o som da palma.

\section{ESTALO DE DEDO}

Muitas pessoas acreditam que o som do estalo é produzido no momento em que o dedo médio ${ }^{12}$ é friccionado com o polegar. Entretanto, este seria somente o impulso. O estalo ocorre justamente quando o dedo médio escorrega e bate embaixo, onde o anelar e o mindinho formam uma espécie de caixa acústica, bem junto à base do dedão.

\section{MÃOS NO CORPO}

Conforme dito anteriormente, é importante conhecer o nosso intrumento musical. Sabemos que uma grande porcentagem do corpo é composta de água e este fator é

\footnotetext{
${ }^{12}$ Utilizamos o dedo médio, apesar de ser possível substituí-lo pelo dedo pelo anelar ou indicador.
} 
determinante na qualidade timbrística de cada sonoridade. O som das palmas, por exemplo, não é produzido somente pelos ossos, e sim, por todo o conjunto de tecidos da mão. Cada parte do corpo possui uma concentração específica de água, influenciando na densidade específica destes tecidos, pele e músculos, produzindo assim sonoridades características. Podemos perceber isto ao percutir as mãos em diversas partes do corpo.

Temos uma curiosa escala de sonoridades, da mais grave à mais aguda, ao percutir nosso corpo de cima para baixo: peito, barriga, coxas e canelas.

Figura 7: Mãos no corpo

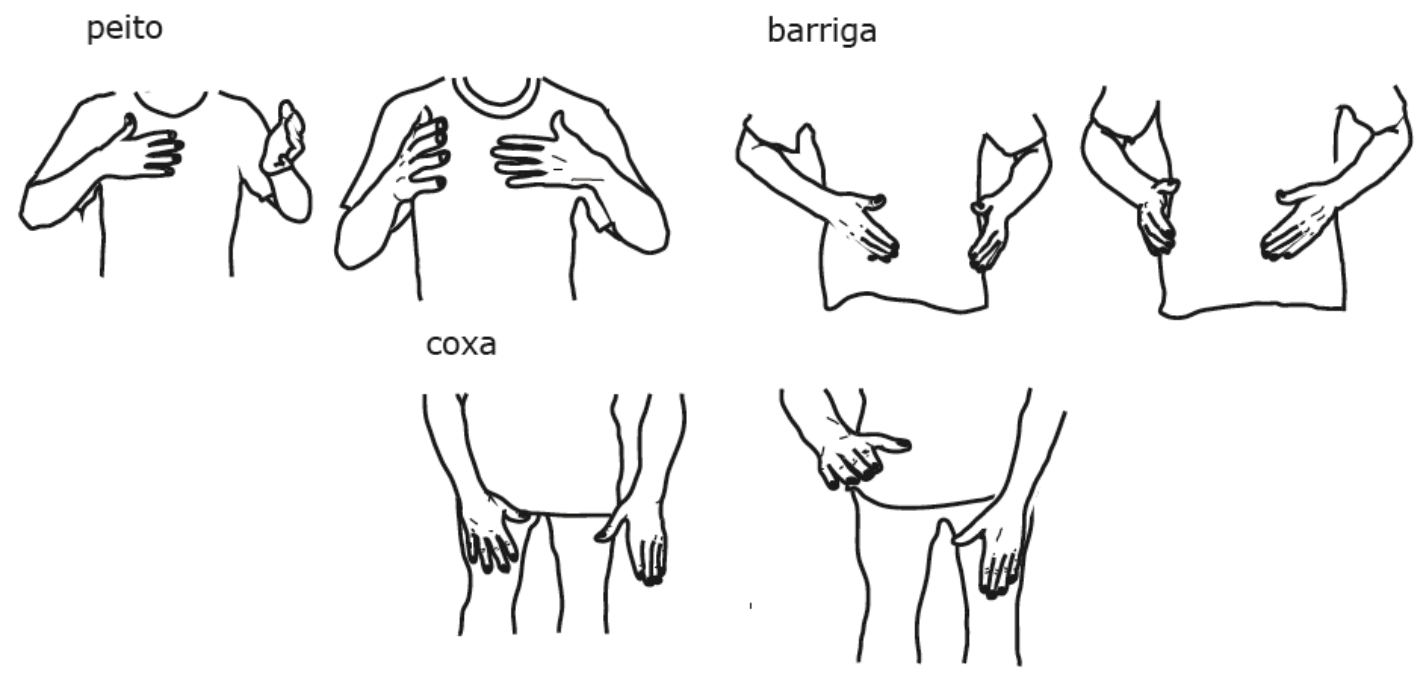

Fonte: Apostila Barbatuques

Podemos também bater as mãos em outras partes, como braços, pescoço, parte anterior da perna, nádegas, região lombar, etc..

É possível produzir sons curiosos e específicos utilizando as mãos na boca, sempre com o cuidado de percutir delicadamente para não machucar.

\section{MÃOS NA BOCHECHA}

Para um tambor ou pandeiro soar, é preciso que o couro ou a pele sintética, presa ao corpo do instrumento, esteja esticada para poder reverberar e amplificar o som. O mesmo precisa ocorrer, com as devidas proporções, com a pele da bochecha. 
Figura 8: Mãos na bochecha

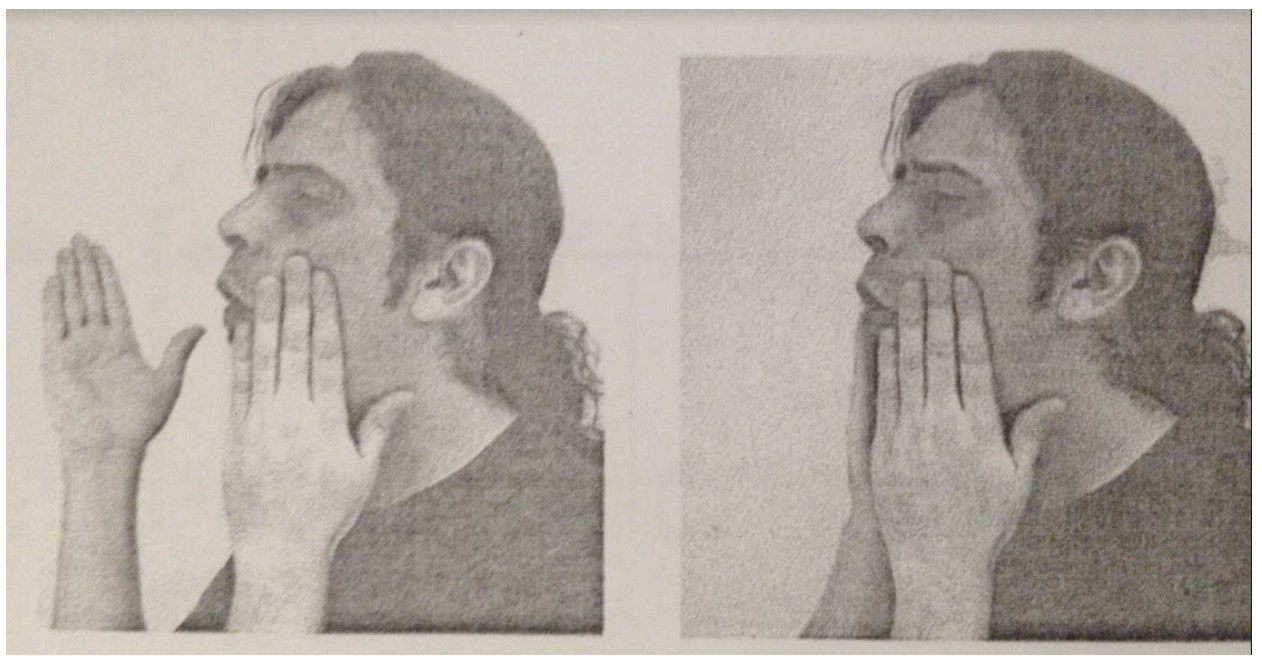

Fonte: Apostila Barbatuques

Ao abrimos a boca no formato da vogal "O", esticamos de modo natural esta pele. Na sequência, batemos suavemente os dedos na parte da bochecha mais próxima à boca, no espaço existente entre a arcada superior e o maxilar. Podemos utilizar as duas mãos alternadamente, evitando apenas bater de modo simultâneo. É mais importante bater com firmeza do que com força.

Podemos variar a altura das notas, modificando lentamente o formato dos lábios, indo da vogal "O" até "A", fazendo assim, uma escala do grave ao agudo.

\section{BOQUINHA}

Para executar este som, fazemos o formato da letra "O" com a boca, deixando os lábios levemente firmes e contraídos. Com uma das mãos, unimos os dedos, deixando-os esticados e batemos na boca com a parte superior. 
Figura 9: Boquinha

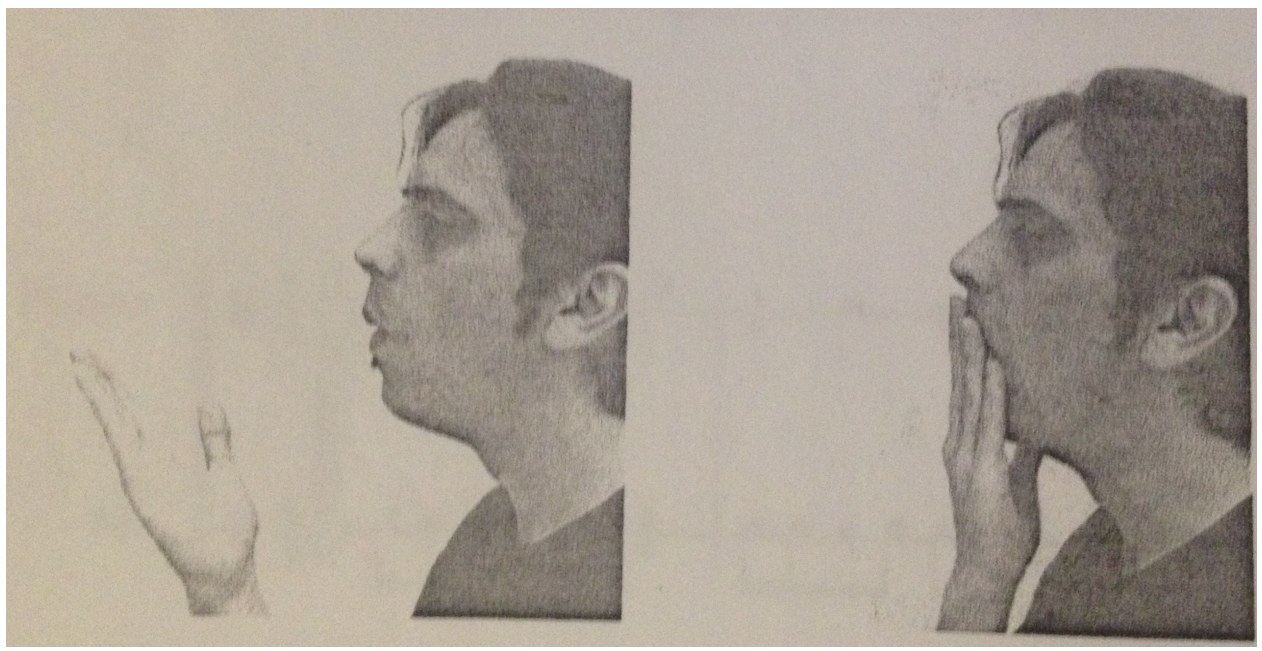

Fonte: Apostila Barbatuques

É possível alternar as mãos. Para criar criar diferentes notas musicais, modificamos o espaço interno da boca através da posição da língua. Neste momento, o formato inicial dos lábios permanece quase inalterável.

POC POC

Primeiro é necessário juntar as duas mãos, palma com palma. Entretanto, deixamos as mãos um pouco curvadas, criando assim um pequeno espaço na parte interna, como se fosse uma pequena concha. Ao batermos uma palma com este formato, será criada uma pequena corrente de ar.

Figura 10: Poc poc

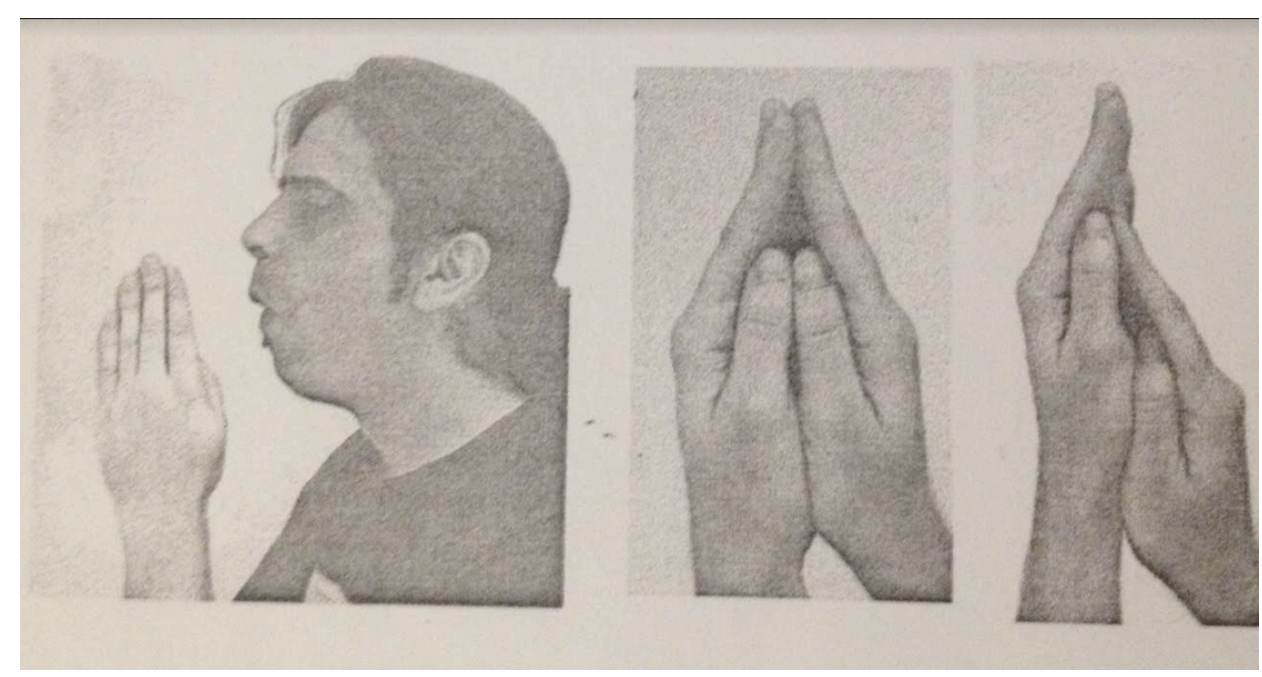

Fonte: Apostila Barbatuques 
Com os lábios em forma de "O", direcionamos este vento para dentro da boca (sem assoprar), criando assim um som característico e uma nota musical definida. É possível alterar a altura das notas para fazer melodias. Neste caso, valem as mesma regras do som da boquinha.

\section{CENTRO SONORO DA BOCA}

Existe uma enorme diversidade de timbres e possibilidades sonoras produzidas pela boca. Podemos classificar basicamente em três grupos: sons que utilizam apenas os lábios e a parte interna da boca, através de atritos, vácuos e sucções; sons de ventos e assobios, que utilizam o ar que vem do pulmão; e, por último, sons emitidos pelas cordas ou pregas vocais.

Muitos destes sons são recomendados por fonoaudiólogos para exercitar o tônus do aparelho vocal, objetivando uma melhor dicção e projeção vocal de seus pacientes. Com isto, é possível afirmar que, além do aspecto lúdico e educativo musical, a utilização destes sons é benéfica e relevante para o treinamento vocal do artista cênico. No anexo desta dissertação de mestrado existe uma lista com símbolos usados como notação de possibilidades sonoras com a boca.

\section{ESTALO DE LÍNGUA}

O famoso som do "cavalinho". Grudamos a língua no céu da boca e através de uma sucção, ela se desprende e cai, criando um som característico.

Figura 11: Estalo de língua

\section{estalo de língua}
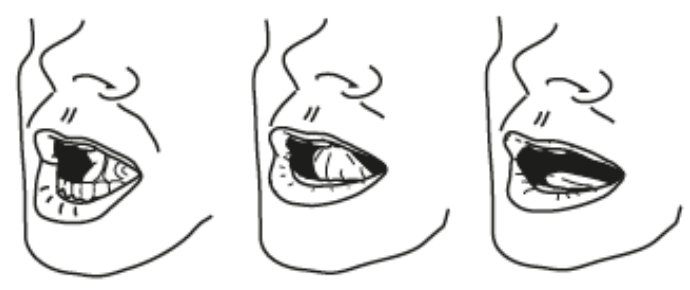

Fonte: Apostila Barbatuques

Se mudarmos o formato da boca durante a execução do som, conseguimos alterar a sua altura. Basta apenas fazer, com os lábios, o formato da letra "o" e ir alterando até a "a". Neste caso, teremos uma escala do grave ("o") ao agudo ("a"). 


\section{ESTALO COM A BORDA DA LÍNGUA}

Parecido com o som anterior mas o vácuo é criado com as bordas laterais da língua mais perto do fundo da boca. Neste caso, é possível fazer o som sem abrir o maxilar.

\section{ESTALO COM A PONTA DA LÍNGUA}

Com a ponta da língua atrás dos dentes da frente, fazemos uma pequena e curta sucção. Pode ser utilizado como gesto teatral, sendo reconhecido como "som de desaprovação”.

\section{BEIJO}

Som produzido ao fazer um beijo.

Figura 12: Beijo

\section{beijo}

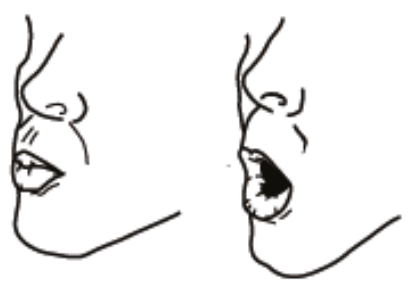

Fonte: Apostila Barbatuques

Podemos variar a duração e a intensidade. O som pode ser curto ou longo e feito de modo suave ou forte.

\section{BEIJO PARA DENTRO (VÁCUO DE BOCA)}

Colocamos os dois lábios dentro da boca enquanto apertamos suavemente os dentes. Fazemos uma pressão de sucção e, neste momento, a boca é repentinamente aberta. 
Figura 13: Vácuo de boca

\section{vácuo de boca}
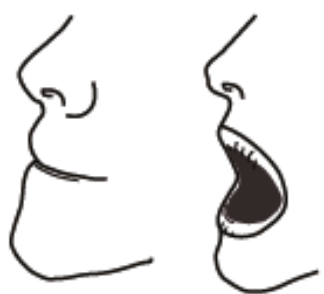

Fonte: Apostila Barbatuques

\section{ESTALO DE LÁBIO}

O início deste som é parecido com o anterior, o vácuo de boca. Entretanto, quando os labios estiverem recolhidos, fazemos o movimento de emitir a letra "b"ou "p".

Figura 14: Estalo de lábio

\section{estalo de lábio}
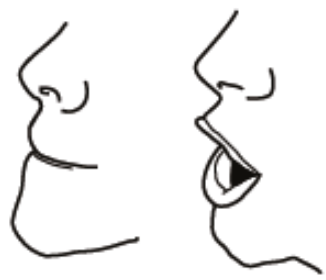

Fonte: Apostila Barbatuques

\section{VENTOS E ASSOBIOS}

Existem diversas possibilidades de fazer sons simulando ventos, brisas e sopros. Sem utilizar as cordas vocais, podem ser feitos através de consonantes ou vogais.

A letra "S" - Sssssssssssssssssssss..

A letra "F" - Fffffffffffffffffffffffffffffff.

A letra "X" - Xxxxxxxxxxxxxxxxxxx...

É possível também emitir estes ventos somente através das vogais. Ao exprimir estes sons, podemos modular as frequências fazendo movimentos com os lábios .

Deste modo, é possível imitar chocalho e ganzás, instrumentos que são considerados 
como emissores de frequências mais agudas.

Exemplo : Txi, sem emitir com as cordas vocais a letra "i”"..

Txi txi txi txi.... Pixxxxx... Tixxxxxx.. Tik xik tik xik tixk..

\section{SONS VOCAIS}

Quando as cordas vocais entram em ação, as possibilidades sonoras ficam imensas. Existem múltiplas pesquisas acadêmicas ou não, sobre a utilização da voz, seja através da fala ou do canto, onde é possível perceber as inúmeras possibilidades de formas de expressão vocal. Devido a esta rica e complexa pluralidade, a presente dissertação de mestrado pretende não aprofundar este tema, utilizando, assim, os sons produzidos pela voz de uma maneira mais simples e lúdica, ligada, principalmente, a uma produção timbrística percussiva e rítmica, através de onomatopeias (Tum, Pá, Txi, Poc, Péin, etc..), vogais, consoantes, imitação de instrumentos e objetos, sons da natureza, paisagens sonoras dentre outros. A partir do capítulo de jogos, aprofundaremos um pouco mais estas possibilidades.

\section{Notação musical - tablaturas e partituras}

O grupo Barbatuques desenvolveu na sua trajetória de pesquisa, duas formas de escrita e registro dos ritmos e músicas corporais que criava.

A primeira foi através de uma notação através de uma partitura bastante similar com o padrão utilizado na música para registrar as escritas para percussão e bateria. No início, Fernando Barba e André Hosoi escreviam estas notações rítmicas de forma mais simplificada $^{13}$ até que Carlos Bauzys transcreveu para a partitura a primeira peça de percussão corporal composta pelo Barba, a música "Barbapapa’s Groove"14.

A segunda forma de escrita foi através da tablatura, que é uma representação gráfica onde é possível identificar os encadeamentos de sons corporais. Ela foi pensada de modo a simplificar a leitura daqueles que não conhecem a notação musical tradicional.

Para um melhor entendimento, segue uma sequência de imagens da apostila utilizada pelo grupo para explicar este assunto de notação e escrita dos ritmos e músicas durante as oficinas de percussão corporal.

\footnotetext{
${ }^{13}$ Ver no anexo.

${ }^{14}$ Ver no anexo.
} 
Figura 15: A Tablatura Corporal

\section{A Tablatura Corporal}

A tablatura corporal é uma representaçäo gráfica para indicar uma sequência de sons e movi mentos do corpo. Ela deve ser lida da esquerda para a direita, como na escrita musical convencional. Cada caixa indica um tempo do compasso. Os quadrados internos indicam as subvivisäes desse tempo.

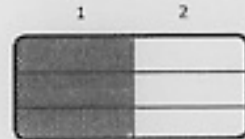

duas subdivisbe

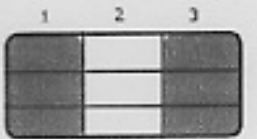

tots subdriscos
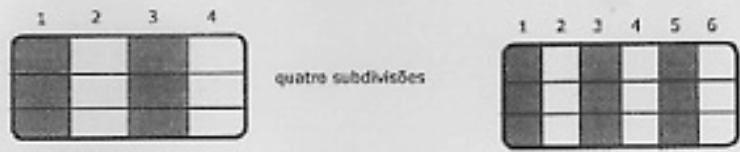

seir suthithisos

É importante que as măos esqucrda e direita se alternem sempre na execuçăo do ritmo, o que proporciona maior agilidade corporal além de preservar uma sequência lógica (sem repotiç̃o de mäus) quanda o ribno é tocado repetidas vezes ou mesmo quando estó em transicso para outro ritmo. Uma certa sensaçăo de uma interrupçło desta alternâncla pode ocorrer as praticante no mornento do toque das palmas, já que este $5 \mathrm{~cm}$ se produz a partir das duas mäos atuando simultaneamente. Neste caso para se manter a lógico binória recomenda-se que a mơo utilizada antes da batida de palmas seja a mesma măo utilizada após a batida de palmas.

A ordern das măos estấ indicada pelas cores amarela e branca. Cado pessoo possui pcraimente uma măo "lider que inicia o movimento: a esquerda ou a direita. Aconselhamos ao praticanto. tentar reconhecer se uma de suas mãos se assume coma a mais natural para iniciar os ntmos, case sim recomenda-se mante-la como iniciante dos rtmos que serdo estudados aqui. Inicie os ritmos descritos sempre começando pelo lado com que tem mais naburalidade.

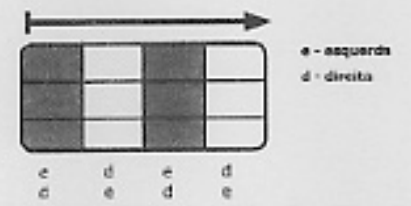

A parte do corpo a ser tocada está indicada à esquerca da tablature com uma bolinha dentro do respectivo quadrado. Ex:

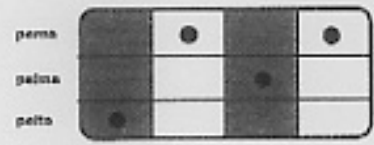


Figura 16: Notação Musical

\section{Notação Musical}

\section{Palmas}

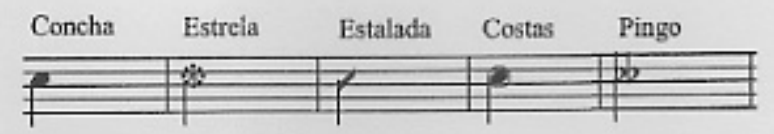

Peito Estalo Perna Barriga Pé inteiro

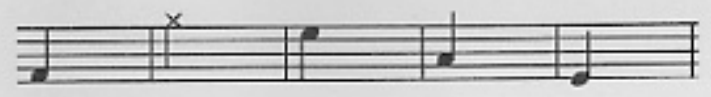

Mão na cabeça

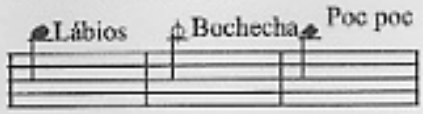


Figura 17: Ritmos peito estalo palma

\section{Ritmos peito estalo palma}
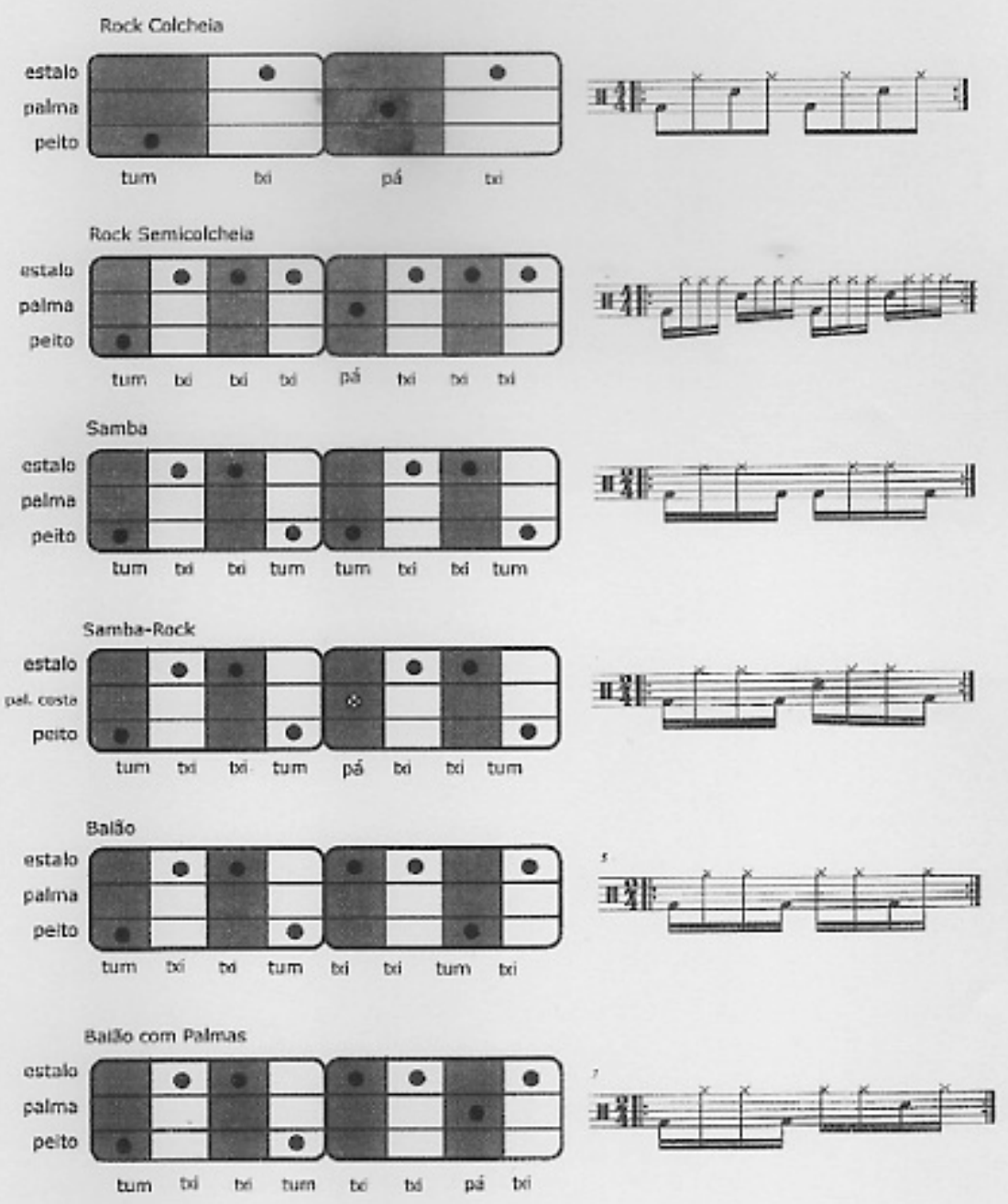
Figura 18: Ritmos combinando pés e mãos

\section{Ritmos combinando pés e mãos}

1
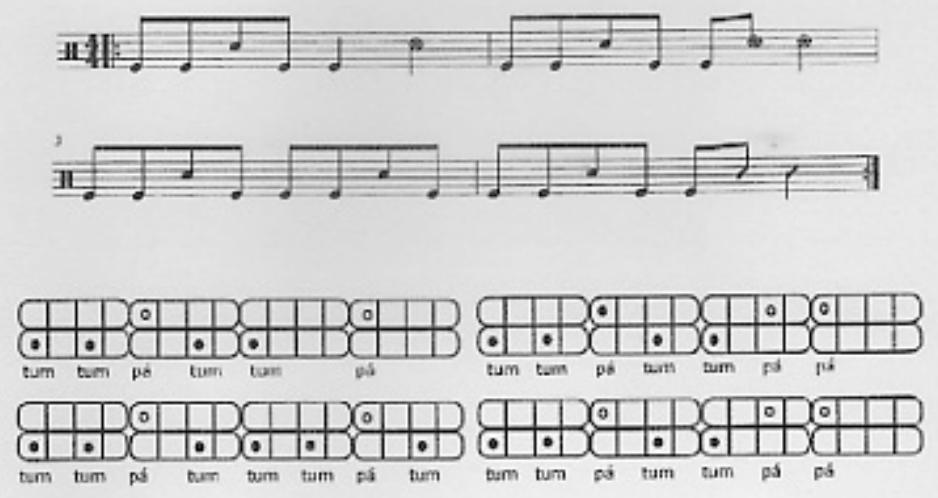

2
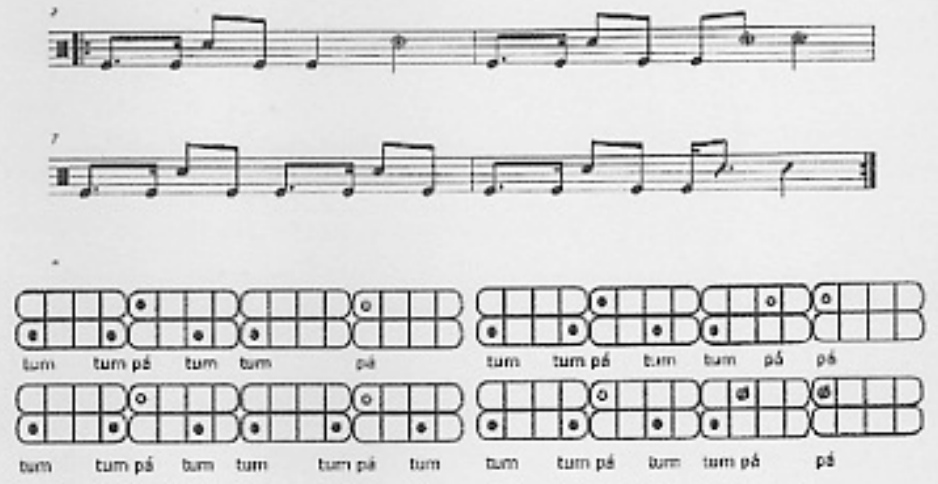
Figura 19: Ritmos adicionais

\section{Ritmos adicionais}
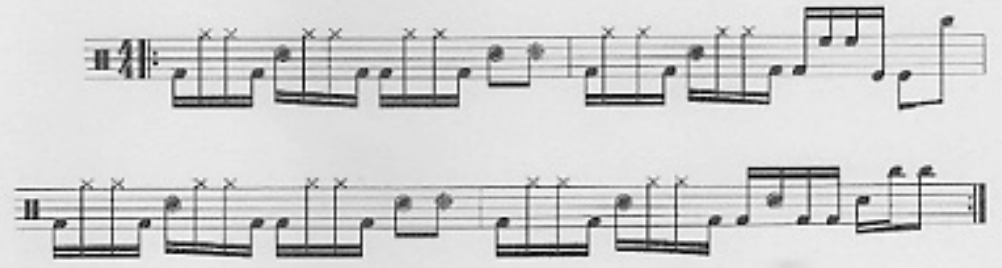

legenda para palmas

- grave $\varnothing$ aguda $\bigcirc$ estrela $\odot$ costas de mão
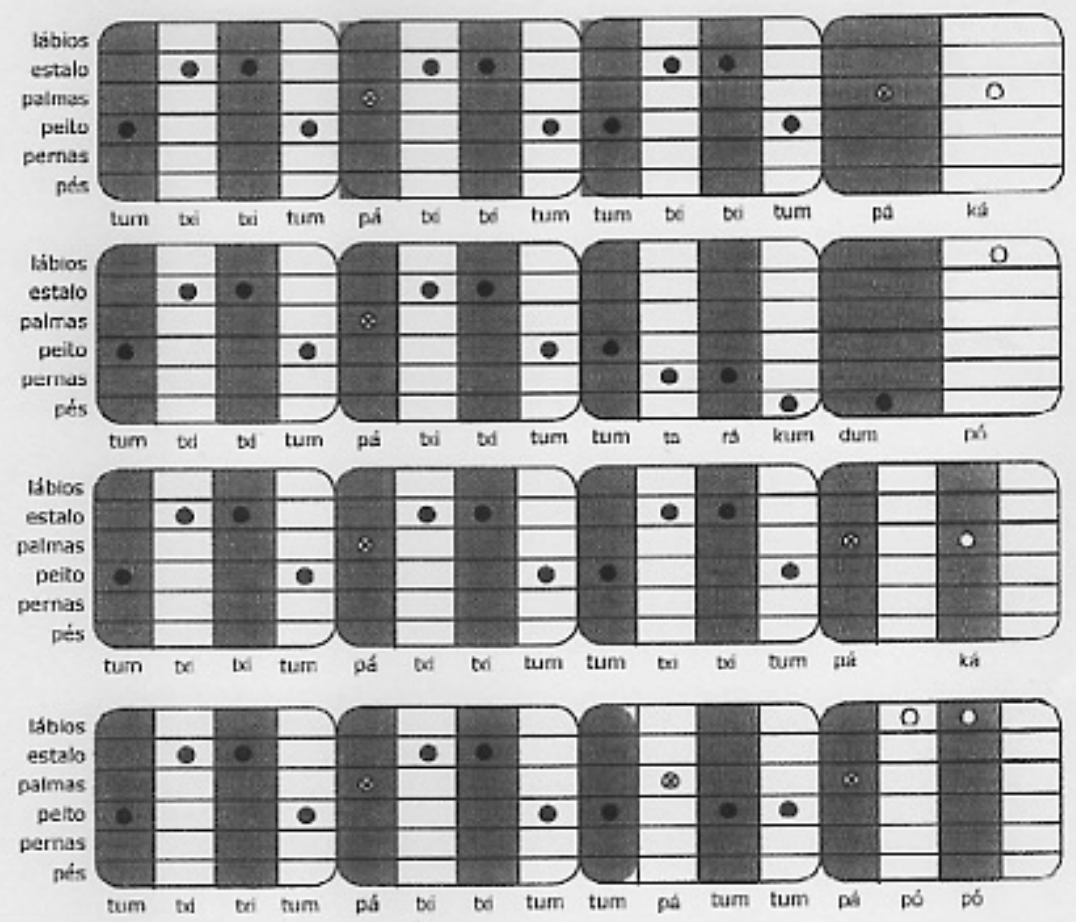

Fonte: Apostila Barbatuques 
Figura 20: Hit Percussivo (CD Tum Pá)

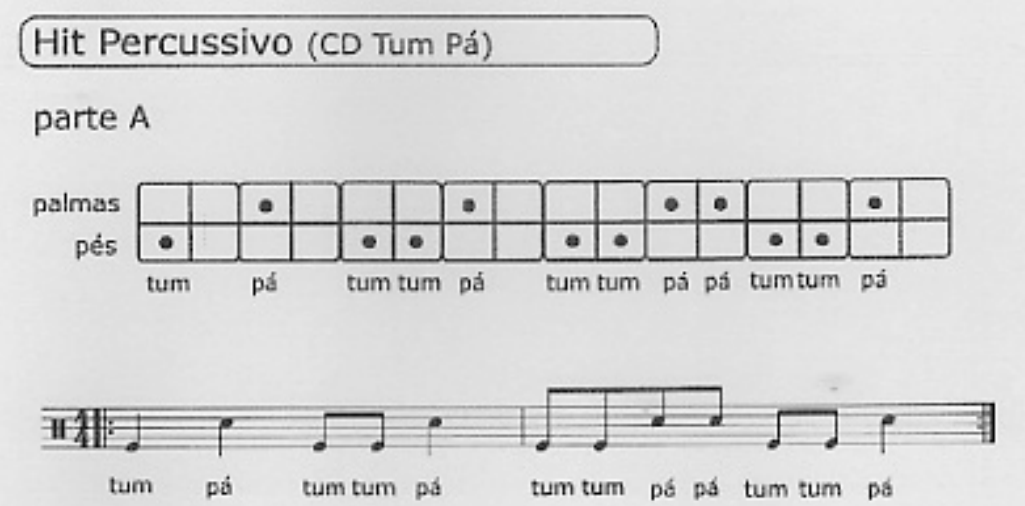

parte B

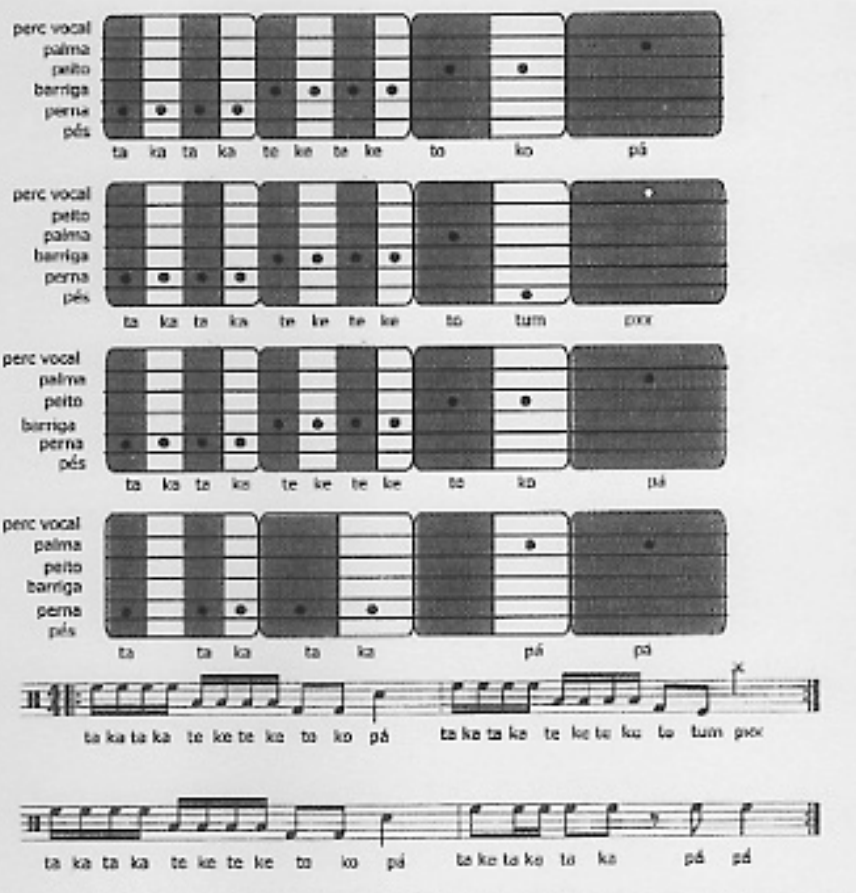




\section{CAPÍTULO III - JOGOS MUSICAIS CORPORAIS}

\section{Introdução e bula}

Neste capítulo, serão abordados e aprofundados alguns jogos desenvolvidos pelo grupo Barbatuques ao longo da sua trajetória de pesquisa. Em cada um deles, será sugerida uma reflexão sobre seu uso pelo artista cênico, estabelecendo, assim, os paralelos propostos na presente dissertação. Importante salientar que o objetivo deste trabalho não é criar uma metodologia e sim, apresentar um aprofundamento de uma pesquisa já existente, possibilitando assim um compartilhamento agregador da linguagem da música corporal no desenvolvimento musical do artista cênico.

O fichário de jogos teatrais de Viola Spolin serviu como inspiração para a escrita e organização deste capítulo. Cada jogo será apresentado da seguinte forma:

- Introdução;

- Instrução;

- Variação;

- Reflexão musical e cênica.

É possível que, em determinadas situações, alguns destes itens sejam suprimidos ou escritos de forma simplificada devido à dinâmica da didática ou ainda, a informação a ser relatada tenha sido abordada no jogo anterior.

Existem três funções de participação: como instrutor (ou coordenador), jogador ou observador/escutador (plateia). No treinamento do jogos, o intrutor não precisa ser, necessariamente, o professor ou o diretor do grupo. É bastante enriquecedor todos passarem pelas três funções.

Os jogos foram escritos seguindo uma determinada sequência apenas como sugestão, para um melhor entendimento. Os conceitos teóricos são explicados no decorrer das atividades, na medida em que aparecem. Entretanto, é perfeitamente possível alterar a ordem apresentada, assim como praticar somente um ou outro jogo.

É necessário um espaço adequado para trabalhar os jogos musicais corporais. Podem ser as mesmas salas e palcos utilizados para o estudo das práticas de teatro e dança, preferencialmente um espaço amplo, com chão de madeira, boa acústica e silenciosa. Porém, 
as atividades também podem ser realizadas em uma sala de aula normal, com as cadeiras afastadas.

Antes de iniciar os jogos, é recomendado sempre fazer um aquecimento corporal e/ou vocal ${ }^{15}$. Podemos estabelecer um paralelo com o músico que afina o seu instrumento antes de tocar. O instrumentista corporal também precisa preparar o seu objeto de trabalho, especialmente joelhos, articulações e extensões vocais, para evitar lesões durante as atividades. Aliás, a segurança corporal é a maior regra de todas. Os jogadores precisam desenvolver uma consciência de responsabilidade perante seu instrumento de trabalho. Jamais deverá insistir em alguma das atividades caso comece a sentir dores ou desconfortos corporais.

É de fundamental importância a instauração de um ambiente concentrado e silencioso por parte de todos. Os pesquisadores precisam ficar bastante atentos no tocante ao uso da fala durante os jogos. Isto diz respeito não apenas em relação à questão da concentração e disciplina, mas também porque o corpo está sendo utilizado, naquele momento, como instrumento de expressão musical. Neste caso, esta sonoridade emitida pode ser entendida como ruído, ou seja, um som indesejável em relação ao campo sonoro pretendido pelo jogo.

Para um aprofundamento maior, é sempre recomendável acontecerem conversas e reflexão entre os participantes. Elas podem ocorrer ao final de cada jogo ou após uma sequência de atividades.

Algumas instruções poderão ser repetidas durante a apresentação dos jogos musicais corporais.

\section{JOGOS DE PULSO E RÍTMICA}

\section{Jogo do Caminhar: pulso, andamentos e intensidades utilizando o Centro Sonoro dos Pés}

O Jogo do Caminhar, como o próprio nome sugere, consiste em andar pelo espaço, percebendo e exercitando possibilidades rítmicas desta ação, tendo como ponto de partida o centro sonoro dos pés.

\footnotetext{
${ }^{15}$ Existem diversos tipos de atividades que podem ser feitos como aquecimento, ficando a critério dos participantes a escolha deste repertório.
} 
Andar é uma das maneiras mais eficazes de trabalhar e desenvolver a noção de pulso. Ao caminhar, andar apressadamente ou até mesmo correr, podemos perceber que, entre um passo e outro, existe, matematicamente, uma mesma quantidade de tempo entre um passo e outro. É muito comum as pessoas dizerem que tem dificuldades ou se sentem incapazes de marcar um pulso. O estudante de teatro precisa aprender a ter controle sobre um pulso.

Muito importante salientar a importância do cuidado com o corpo, especialmente nos jogos que utilizam os pés e pernas. Existe uma série de ligamentos nestas regiões, especialmente nos joelhos, onde é fundamental ter um cuidado específico. É função do coordenador alertar os jogadores quanto ao risco de lesão especialmente nestas articulações, caso seja utilizada uma força excessiva no pisar. Aconselhável realizar um pequeno aquecimento e alongamento corporal.

Se porventura houver um jogador que por algum motivo esteja com dificuldades de utilizar seus pés ou impossibilitado de andar, o instrutor pode sugerir outras alternativas de participação, incluindo-o, de alguma maneira, nas atividades (sentado no chão ou na cadeira dentro do espaço de jogo; perceber se é possível algum colega auxiliá-lo na caminhada; etc..).

Todos os jogos de caminhada também podem ser realizados de maneira estática, com os jogadores dispostos em roda, utilizando um ou mais círculos (dependendo da relação entre o número de participantes e o tamanho da sala ou espaço de trabalho).

$\mathrm{O}$ quadro a seguir apresenta as propriedades de três características que podem ser utilizadas e combinadas nos jogos do caminhar: direções, tipos e qualidades. 
QUADRO DAS PROPRIEDADES (direções, tipos e qualidades)

\begin{tabular}{|ll|}
\hline Direções de deslocamento com os pés: \\
\hline 1) & Frente \\
\hline 2) & Trás \\
\hline 3) & Lados (esquerda e/ou direita) \\
\hline 4) & Diagonais \\
\hline 5) & Movimentos circulares \\
\hline & \\
\hline Tipos de deslocamento com os pés: \\
\hline 1) & Passos normais \\
\hline 2) & Passos largos \\
\hline 3) & Passos curtos \\
\hline 4) & Passos arrastados (neste caso a planta inteira do pé ou parte dela se mantém encostada \\
& no chão durante a trajetória dos passos) \\
\hline & \\
\hline Qualidades de deslocamento com os pés: \\
\hline 1) Ponta dos pés \\
\hline 2) & Borda externa dos pés \\
\hline 3) & Borda interna dos pés \\
\hline 4) & Calcanhar \\
\hline
\end{tabular}

Além destas propriedades dos passos, também podem ser explorado os timbres, intensidades e andamentos dos pés:

- Timbres causados pelos tipos de calçados (sapatos, botinas, botas ${ }^{16}$, tamancos, chinelas, etc..) e solados (borracha, madeira, sapatos com chapas de metal ${ }^{17}$, pés descalços, etc..).

- Intensidade (volume) do som do pé (fraco, moderado ou forte).

- Andamento (velocidade) do pulso ao caminhar.

\footnotetext{
${ }^{16}$ Temos como exemplo o Gumboots, manifestação cultural criada pelos mineradores de diamante na África do Sul. Como eram obrigados a utilizar, em seus trabalhos, botas de borracha cano alto, elaboraram uma espécie de dança musical bastante rítmica. Inspirada em danças tradicionais africanas, a técnica de Gumboot consiste em intercalar palmas e sapateados com o som das mão percutindo vigorosamente as laterais e outras partes das botas.

${ }^{17}$ Sapatos de tap dance são utilizados, principalmente, no estilo musical norte americano.
} 


\section{Situação 1 - Caminhada espontânea sem pulso coletivo}

\section{DESCRIÇÃO}

O Jogo do Caminhar contém diversas etapas, sendo que a primeira delas é apenas se deslocar, livremente, dentro do espaço delimitado de trabalho, tendo cuidado para não se chocar com os demais jogadores. Todos são estimulados a pesquisar as diversas direções e qualidades de deslocamento dos pés ${ }^{18}$ enquanto caminham. Em determinado momento, para sensibilizar a escuta, o instrutor pede para que todos, sem parar a atividade, direcionem o foco para a escuta da somatória dos sons produzidos pelos pés.

\section{VARIAÇÃO}

Uma possível variação para trabalhar o foco e a concentração é utilizar o jogo teatral "Quando um pára, todos param. Quando um anda, todos andam". Como o próprio título sugere, todos caminham prestando atenção aos demais e, no momento em que um jogador parar, todos os outros devem fazer igual o mais rápido possível, de forma que o instrutor não seja capaz de descobrir quem foi o primeiro a cessar o movimento. O mesmo acontece quando alguém retoma a caminhada.

Para um maior aprofundamento da sensibilização corpóreo-motor, podemos também utilizar o jogo Caminhada no Espaço \#1, do fichário de Viola Spolin` De acordo com a sua descrição, "os jogadores caminham e investigam fisicamente o espaço como se este fosse uma substância desconhecida." (SPOLIN, 2001, f. A6)

\section{REFLEXÃO MUSICAL E CÊNICA}

Através do simples ato de caminhar, os jogadores podem perceber as possíveis relações entre seus corpos e o espaço onde estão. Neste caso, a pesquisa das diversas direções e qualidades de deslocamento colaboram também neste processo de autoconhecimento corporal.

O momento em que é solicitado o foco na escuta dos passos pode servir para ampliar a percepção sonora do próprio jogador em relação a si e aos outros. Esta seria uma primeira sensibilização sonora sobre o tocar de modo individual e coletivo. Estas questões serão aprofundadas nos próximos jogos.

\footnotetext{
${ }^{18}$ Consultar quadro das propriedades pág. 57.
} 
Sobre os jogos de caminhar, Viola Spolin diz:

(..) mais do que exercícios de percepção sensorial, são maneiras orgânicas de perceber/sensibilizar/experienciar o ambiente (espaço) à nossa volta como uma dimensão atual na qual todos entram, comunicam, vivem e são livres. Distrações são abandonadas e os jogadores são ajudados a entrar no momento presente, com outros jogadores e com formas e objetos. Cada jogador torna-se instrumento receptivo/emissor capaz de ir além de seu ser físico e do ambiente imediato. A Caminhada no Espaço invariavelmente cria um estado de alerta e um sentido de pertencimento e conexão (Parte do Todo). Assim como a água alimenta a vida marinha, a substância do espaço nos envolve e alimenta. Cada qual no seu espaço abre espaço para os outros. Isto será intuitivamente compreendido pelos jogadores" (SPOLIN, 2001, manual de instruções pag. 41)

Com isto, podemos observar que os jogos musicais relacionados ao caminhar podem colaborar diretamente com o desenvolvimento de um ator mais consciente acerca desta relação corporal e espacial.

No jogo “quando um pára..”, tão importante quanto caminhar é justamente saber como parar de caminhar e na sequência, como retomar a caminhada. Esta proposta de estimular a percepção corporal obriga os jogadores a ampliarem seu grau de sensibilidade em relação ao espaço e a seus próprios corpos.

\section{Situação 2 - Caminhada com pulso regular}

\section{INTRODUÇÃO}

Na música, um pulso pode ser considerado como uma unidade de tempo. Pulso regular significa que esta unidade temporal acontece repetidamente através de uma determinada frequência, em que os espaços de tempo entre cada pulso são iguais e constantes.

Durante o caminhar, é possível perceber a existência de um pulso regular, afinal, em condições normais, as pernas sempre se locomovem de maneira uniforme. O mesmo ocorre quando andamos apressadamente ou corremos, o tempo entre o tocar de cada pé no chão se mantém equivalente. 


\section{INSTRUÇÃO}

O jogo inicia do mesmo modo que o anterior, com todos caminhando, cada qual em seu próprio andamento. Em determinado momento, o instrutor dá as seguintes instruções: "Agora, sem parar de caminhar, procurem, aos poucos, andarem juntos em um mesmo pulso! Deixem fluir para que aconteça de forma natural e coletiva!".

Agora todos caminham de forma a coincidir o momento em que os pés tocam o chão, estabelecendo assim um pulso regular em comum. Após este momento, o instrutor pede para que todos, ainda no pulso, explorem as direções e qualidades com os pés ${ }^{19}$.

\section{VARIAÇÃO}

É possível todos caminharem no pulso com a mesma ordem das pernas. Em um pulso, todos dão um passo com o pé direito e no próximo com o esquerdo.

O jogo "Quando um pára todos param..." também pode ser utilizado durante o estudo da caminhada com pulso regular.

\section{REFLEXÃO MUSICAL E CÊNICA}

É dever do artista cênico entender racionalmente e se apropriar corporalmente do entendimento de pulso, afinal este é a unidade básica para todo o estudo do ritmo.

\footnotetext{
"Todo ator, todo encenador sabe intuitivamente da importância do ritmo tanto para o trabalho vocal e gestual, como para o desenrolar do espetáculo. A noção de ritmo não é então uma ferramenta semiológica recém-inventada para a leitura do texto dramático ou para a descrição da representação. Ela é constitutiva da própria fabricação do espetáculo.”(PAVIS, 342)
}

Em relação ao jogo “Quando um pára..”, é possível perceber uma dificuldade maior em todos pararem ao mesmo tempo. A tendência é sempre sobrar o passo de algum jogador. Ao retomar a caminhada, a dificuldade pode existir no ajuste exato de um pulso coletivo.

\footnotetext{
${ }^{19}$ Consultar quadro das propriedades pág. 57.
} 
Situação 3 - Caminhada com pulso regular e variação de andamento (lento, médio e rápido)

\section{INTRODUÇÃO}

Agora que todos os jogadores conseguem executar um pulso de maneira regular e coletiva, podemos aprofundar o estudo das diversas velocidades.

Através da quantidade de pulsos por minuto $\left(\mathrm{bpm}^{20}\right)$, é possível identificar os andamentos, que podem ser divididos em três grupos básicos: lento, médio ou rápido. $\mathrm{O}$ andamento médio está relacionado à velocidade de uma pessoa ao andar normalmente. Entretanto em cada um deste grupos existem subdivisões, conforme podemos perceber a seguir.

\footnotetext{
${ }^{20}$ Beat per minute, ou batidas por minuto.
} 
Figura 21: Andamentos

\begin{tabular}{|c|c|c|}
\hline ANDAMENTO & B.P.M. & DEFINIÇÃO \\
\hline Gravissimo & Menos de 40 & Extremamente lento \\
\hline Grave & 40 & Muito vagarosamente e solene \\
\hline Larghissimo & $40-60$ & Muito largo e severo \\
\hline Largo & $40-60$ & Largo e severo \\
\hline Larghetto & $60-66$ & Mais suave e ligeiro que o Largo \\
\hline Lento & $60-66$ & Lento \\
\hline Adagio & $66-76$ & Vagarosamente, de expressão terna \\
\hline Adagietto & $66-76$ & Vagarosamente, pouco mais rápido que Adagio \\
\hline Andante & $76-108$ & Velocidade do andar humano, amável e elegante \\
\hline Andantino & $84-112$ & Mais ligeiro que o Andante, agradável e compassado \\
\hline Moderato & $108-120$ & Moderadamente (nem rápido, nem lento) \\
\hline Allegretto & $112-120$ & $\begin{array}{l}\text { Nem tão ligeiro como o Allegro; também chamado de } \\
\text { Allegro ma non troppo }\end{array}$ \\
\hline Allegro & $120-168$ & Ligeiro e alegre \\
\hline Vivace & $152-168$ & Rápido e vivo \\
\hline Vivacissimo & $168-180$ & $\begin{array}{l}\text { Mais rápido e vivo que o Vivace; também chamado de } \\
\text { molto vivace }\end{array}$ \\
\hline Presto & $168-200$ & Veloz e animado \\
\hline Prestissimo & $200-208$ & Muito rapidamente, com toda a velocidade e presteza \\
\hline
\end{tabular}

Fonte: Wikipedia

É perfeitamente possível o instrutor propor as velocidades de forma intuitiva mas para um estudo mais aprofundado, é recomendável o uso de um metrônomo ${ }^{21}$ durante os jogos (amplificar através de uma caixa de som, caso necessário).

\footnotetext{
${ }^{21}$ Aparelho sonoro utilizado para marcar o tempo.
} 


\section{INSTRUÇÃO}

Com os jogadores dispostos no espaço de trabalho, o instrutor faz, oralmente, uma contagem de quatro tempos $(1,2,3,4)$, indicando a pulsação que será trabalhada. Ao final desta contagem, todos iniciam o caminhar no pulso sugerido. Após um determinado momento, o instrutor pede para que todos parem de caminhar, faz uma nova contagem de quatro tempos em outra pulsação para então a caminhada recomeçar. Este procedimento é repetido em diversos andamentos.

\section{VARIAÇÃO}

A cada pausa, o instrutor pode aumentar a velocidade do pulso de forma gradual. Durante o jogo, os jogadores também podem explorar as diversas direções e qualidades com os pés ${ }^{22}$ nos diferentes andamentos propostos.

\section{REFLEXÃO MUSICAL E CÊNICA}

É importante o artista cênico estar apropriado do conceito temporal de velocidade, para ser capaz de dominá-lo durante uma atuação. Ele dever ter consciência que as falas do personagem, assim como a gestualidade e a movimentação corporal, mudam completamente de intenção e sentido a cada velocidade. É possível perceber neste sentido, ao observar o quadro de andamentos ${ }^{23}$ que a maioria das palavras utilizadas para definir fisicamente cada um deles remete diretamente às qualidades de ações físicas. Por exemplo: lento, solene, agradável, alegre, etc.

\section{Situação 4 - Caminhada com variação de intensidade (volume fraco, médio e forte)}

\section{INTRODUÇÃO}

Após os jogadores aprofundarem o estudo das diversas velocidades de deslocamento no jogo da caminhada, torna-se fundamental introduzir o conceito de intensidade sonora. Esta propriedade diz respeito ao volume do som, ou seja, sobre a força com que os pés tocam o chão na medida em que o jogo evolui.

\footnotetext{
${ }^{22}$ Consultar quadro das propriedades pág. 57.

${ }^{23}$ Consultar quadro dos andamentos pág. 62.
} 
Abaixo segue a relação das intensidades de volume.

Figura 22: Intensidades

\begin{tabular}{|r|c|l|}
\hline $\begin{array}{l}\text { INTENSIDADE } \\
\text { (DINÂMICA DO SOM) }\end{array}$ & ABREVIATURA & DEFINIÇÃO \\
\hline Molto Pianissimo & $p p p$ & $\begin{array}{l}\text { Extremamente suave (fraco), quase não se } \\
\text { percebe o som }\end{array}$ \\
\hline Pianissimo & $p p$ & Bastante suave \\
\hline Piano & $p$ & Suave \\
\hline Mezzo-piano & $m p$ & $\begin{array}{l}\text { Volume médio, moderadamente suave, um } \\
\text { pouco mais intenso que o piano }\end{array}$ \\
\hline Forte & $f f$ & Moderadamente forte \\
\hline Fortissimo & $f f$ & Forte \\
\hline Molto Fortissimo & $f f f$ & $\begin{array}{l}\text { Extremamente forte (sem danificar o } \\
\text { instrumento) }\end{array}$ \\
\hline
\end{tabular}

Fonte: Wikipedia

Em relação ao volume dos pés, podemos simplificar em três tipos: fraco, médio e forte. Estes seriam respectivamente Pianissimo, Mezzo-piano e Forte.

\section{INSTRUÇÃO}

Escolhendo, inicialmente, um andamento confortável (entre o Lento e o Andante ${ }^{24}$ ), o instrutor agora sugere para todos caminharem uma determinada quantidade de passos, alternando a dinâmica sem alterar a velocidade. Durante o jogo, ele vai indicando as mudanças, sem interromper a caminhada.

Segue uma sugestão introdutória, utilizando somente passos fracos e fortes:

1) Quatro passos com o volume fraco e quatro passos com o volume forte, repetidamente.

\footnotetext{
${ }^{24}$ Consultar quadro de andamentos pág. 62.
} 
2) Três passos com o volume fraco e três passos com o volume forte, repetidamente ${ }^{25}$.

3) Três passos com o volume fraco e dois passos com o volume forte, repetidamente ${ }^{26}$.

4) Dois passos com o volume fraco e três passos com o volume forte, repetidamente.

5) Dois passos com o volume fraco e dois passos com o volume forte, repetidamente.

6) Um passo com o volume fraco e um passo com o volume forte, repetidamente.

\section{VARIAÇÃO}

É importante salientar que nos exemplos acima foram utilizados somente sons fracos e fortes, sendo perfeitamente possível substituir um deles por sons de outras intensidades ${ }^{27}$.

O instrutor ou os jogadores podem criar novas sequências (por exemplo, cinco passos com o volume fraco e três passos com o volume forte ou nove passos com o volume fraco e sete passos com o volume forte, etc..).

Também é possível alterar a intensidade sonora durante a caminhada, aumentando ou diminuindo gradualmente (ou subitamente) a dinâmica, sem a alteração da pulsação.

Segue abaixo o quadro de transição de intensidade:

Figura 23: Transição de intensidade

\begin{tabular}{|r|c|l|}
\hline $\begin{array}{c}\text { TRANSIÇÃO DE } \\
\text { INTENSIDADE }\end{array}$ & SÍMBOLO & DEFINIÇÃO \\
\hline Diminuendo & $>$ & Diminuição progressiva da intensidade \\
\hline Crescendo & $<$ & Aumento progressivo da intensidade \\
\hline Sforzando & $\mathbf{s f z}$ & Crescimento súbito de intensidade durante uma nota \\
\hline
\end{tabular}

Fonte: Wikipedia

\footnotetext{
${ }^{25}$ Reparar que neste exemplo de três tempos, haverá uma alternância da perna que inicia o movimento. Se começarmos o movimento forte com a perna direita, o movimento fraco iniciará com a perna esquerda e assim por diante.

${ }^{26}$ Neste exemplo estamos trabalhando com uma organização temporal de cinco tempos, além da alternância de pernas. Se começarmos o movimento forte com a perna direita, o movimento fraco iniciará com a perna esquerda e assim por diante.

${ }^{27}$ Consultar tabela de intensidades na pág. 64.
} 
Neste sentido, um possível jogo é o da "Caminhada com Transição de Intensidade". Assim que o instrutor fizer a contagem de quatro tempos, todos iniciam, juntos, a caminhada em um pulso regular e de forma bem suave. Os sons vão ficando mais fortes

\section{REFLEXÃO MUSICAL E CÊNICA}

Uma tendência natural observada nas oficinas de percussão corporal é o aumento involuntário da velocidade do pulso conforme a intensidade do tocar aumenta, seja no caminhar ou nas mãos percutindo o corpo. Este fenômeno, geralmente, ocorre quando se coloca mais força em cada uma das batidas, aumentando, assim, o tônus corporal. Importante o coordenador estar atento, alertando o grupo para não acelerar o andamento e ter controle da energia aplicada.

É de fundamental importância o artista teatral ter domínio sobre as diversas intensidades corporais, seja através de movimentos físicos ou durante suas falas em cena. Existem diferentes sutilezas de intensidade entre um sussurro e um grito visceral, por exemplo. Do mesmo modo que os músicos dominam esta capacidade através de seus intrumentos musicais, o ator precisa este domínio técnico sobre o seu próprio corpo, instrumento de sua expressividade. É possível perceber que cada intensidade de energia aplicada, seja nos sons ou movimentos corporais, gera um efeito distinto em cena e este estudo pode auxiliar o artista teatral a ter mais propriedade sobre aquilo que está querendo expressar corporalmente.

\section{Situação 5 - Caminhada com variação de andamento (lento, médio e rápido) e intensidade (volume fraco, médio e forte)}

\section{INTRODUÇÃO}

Este jogo serve para unir os diversos aspectos trabalhados até então, combinando diferentes andamentos e intensidades. 


\section{DESCRIÇÃO}

Seguindo as instruções da Situação $4^{28}$, o instrutor escolhe alguma sequência de pés fracos e fortes, faz uma contagem de quatro tempos em um pulso mais devagar ou mais acelerado e, então, todos os jogadores reiniciam a caminhada. A atividade é retomada sempre alterando os andamentos e intensidades.

\section{VARIAÇÃO}

Durante o jogo, também é possível continuar a exploração das diversas qualidades e direções de deslocamento ${ }^{29}$.

É importante estimular o jogador a perceber como o seu próprio corpo reage a cada um dos andamentos e como são, em relação ao tônus corporal, os diferentes diálogos entre velocidade e intensidade ao caminhar.

\section{REFLEXÃO MUSICAL E CÊNICA}

Diferente da situação anterior, em que o pulso estava situado em uma região confortável entre o Lento e o Andante, agora são exploradas as velocidades mais lentas ou mais rápidas, objetivando os jogadores a terem um controle corporal mais aprofundado sobre estas velocidades extremas.

\section{Jogo do Caminhar: pulso, andamentos e intensidades utilizando combinações entre os três Centros Sonoros}

\section{Situação 6 - Caminhada com pulso livre e palmas espontâneas}

\section{INTRODUÇÃO}

Após a exploração aprofundada do pulso através dos pés e do caminhar, será iniciada a combinação com os demais centros (mãos e boca) ${ }^{30}$, iniciando a integração dos três centros sonoros.

Nos jogos a seguir, podemos utilizar quaisquer tipos de palmas ${ }^{31}$ : grave, estrela, costas de mão, pingo ou estalada, sendo esta última a mais espontaneamente ${ }^{32}$ utilizada. $^{2}$

\footnotetext{
${ }^{28}$ Consultar pág. 63.

${ }^{29}$ Consultar tabela na pág. 57.

${ }^{30}$ Ver Centros Sonoros no capítulo 2.
} 
Também é possível substituí-la por outros sons produzidos pela boca ${ }^{33}$, dando preferência por alguma sonoridade mais percussiva, seca e de curta duração, como estalos de língua, onomatopeias entre outros. Neste caso, é recomendado evitar notas vocais longas.

\section{INSTRUÇÃO}

Nesta nova série, as orientações da Situação 1 são retomadas ${ }^{34}$, porém, o coordenador combina previamente com os jogadores três comandos:

- Comando 1: Os jogadores caminham livremente pelo espaço, de maneira espontânea, sem instaurar um pulso coletivo e sem bater palmas.

- Comando 2: Os jogadores batem palmas de maneira livre e espontânea enquanto andam livremente pelo espaço, sem instaurar um pulso coletivo com os pés.

- Comando 3: Os jogadores param de caminhar, cessando os sons com os pés, e batem palmas de maneira livre e espontânea.

O jogo inicia com o Comando 1. A partir de um determinado momento, os outros comandos são enunciados para os participantes, que modificam os movimentos após cada instrução ser anunciada. É importante todos combinarem, antes do jogo começar, como será feita a mudança da instrução de comando (esta questão será aprofundada mais à frente, nos jogos de regência). Nas oficinas de Barbatuques, existem duas possibilidades: sem interromper o fluxo do jogo, o coordenador pode avisar a alteração e os jogadores executam o comando automaticamente, ou é possível todos escutarem primeiro a instrução e somente mudar após o instrutor fazer um sinal preestabelecido, uma palma por exemplo. Fica a critério do coordenador criar e sugerir diversas possibilidades de sequências e combinações de comandos.

\footnotetext{
${ }^{31}$ Ver tipos de palmas no capítulo 2.

${ }^{32}$ Geralmente a palma estalada é utilizada nas situações cotidianas, como nos aplausos ou quando cantamos a música "Parabéns a você". Também é muito usada para chamar os moradores de uma casa, substituindo assim a campainha.

${ }^{33}$ Consultar os sons de boca no capítulo 2.

${ }^{34}$ Consultar pág. 58.
} 


\section{VARIAÇÃO}

O coordenador pode sugerir, durante o jogo, algumas mudanças de dinâmicas, trabalhando com diversas intensidades de volumes dos pés e das palmas ${ }^{35}$, além de pesquisar as diversas direções e qualidades de deslocamento com os pés ${ }^{36}$.

É sempre importante lembrar que podemos substituir as palmas por sons da boca $^{37} \mathrm{e}$ vice-versa.

\section{REFLEXÃO MUSICAL E CÊNICA}

Dependendo do volume sonoro produzido pelo grupo durante a atividade, poderá existir uma certa dificuldade na escuta dos comandos. Importante os jogadores estarem atentos em relação a esta questão. O coordenador pode propor uma sensibilização da escuta, pedindo para que todos ouçam a somatória dos sons gerados.

\section{Situação 7 - Caminhada com pulso regular e palmas espontâneas}

\section{INSTRUÇÃO}

Este jogo é bem parecido com o anterior. Entretanto, ao invés de cada jogador caminhar livremente pelo espaço, desta vez todos precisam andar juntos, marcando com os pés um pulso regular proposto pelo instrutor ${ }^{38}$.

- Comando 1: Todos os jogadores caminham marcando um mesmo pulso regular com os pés.

- Comando 2: Os jogadores batem palmas de maneira livre e espontânea enquanto continuam caminhando e marcando um mesmo pulso regular com os pés.

- Comando 3: Os jogadores param de caminhar, cessando os sons com os pés, e batem palmas de maneira livre e espontânea.

\footnotetext{
35 Consultar quadro de intensidades na pág 64.

${ }^{36}$ Consultar página 57.

${ }^{37}$ Consultar capítulo 2.

${ }^{38}$ Consultar pág. 61.
} 


\section{VARIAÇÃO}

Assim como os outros jogos de caminhada, é possível praticar em diversos andamentos e intensidades (dos pés e das palmas), além das diversas direções e qualidades ${ }^{39}$.

Lembrar que podemos substituir as palmas por sons da boca e vice-versa.

\section{REFLEXÃO MUSICAL E CÊNICA}

Um fator importante a ser percebido é se o pulso nos pés influencia ritmicamente, de alguma forma, as palmas. É bastante comum perceber, nesta atividade, jogadores batendo as mãos juntos com os pés, marcando o pulso ou fazendo subdivisões mais complexas, muitas vezes de forma intuitiva e despretensiosa. Aqui, podemos começar a notar como o pulso e a rítmica estão, de alguma forma, muito mais presentes e assimilados dentro de cada participante do que, muitas vezes, eles mesmos podem considerar.

\section{Situação 8 - Caminhada com pulso regular com alternância de pés e palmas}

\section{INSTRUÇÃO}

Agora os pés e as palmas podem ser tocados alternadamente. O coordenador escolhe um pulso regular, faz a contagem de quatro tempos e quando acabar, todos começam a caminhada, inicialmente, na seguinte ordem:

- Quatro passos e, em seguida, quatro palmas. Repetir a sequência por mais algumas vezes.

- Três passos e, em seguida, três palmas. Repetir a sequência por mais algumas vezes.

- Três passos e, em seguida, duas palmas ${ }^{40}$. Repetir a sequência por mais algumas vezes.

- Dois passos e, em seguida, três palmas. Repetir a sequência por mais algumas vezes.

- Dois passos e, em seguida, duas palmas. Repetir a sequência por mais algumas vezes.

\footnotetext{
${ }^{39}$ Ver pág. 57.

${ }^{40}$ Notar que, neste momento, está sendo trabalhado um pulso ímpar de cinco tempos.
} 
- Um passo e, em seguida, uma palmas. Repetir a sequência por mais algumas vezes.

- Apenas passos com os pés, no pulso, sem palmas. Repetir a sequência por mais algumas vezes.

A ideia é encadear todas as sequências, sem fazer pausas durante as transições. No final, todos devem comparar o pulso atual com o andamento inicial. Geralmente, a tendência é do pulso estar bem mais acelerado do que no início do jogo. O coordenador deve repetir a sequência por mais algumas vezes, tendo a liberdade de criar sequências, alternando pés e palmas. Por exemplo: um passo e quatro palmas, cinco passos e sete palmas, etc..

\section{VARIAÇÃO}

Assim como os outros jogos de caminhada, nesta situação é possível praticar os diversos andamentos e intensidades (dos pés e das palmas), além das direções e qualidades. Também podemos criar sequências pré-combinadas, neste caso importante perceber que estamos entrando no campo da composição, criando assim pequenas peças rítmicas.

Lembrar que podemos substituir as palmas por sons da boca e vice-versa.

\section{Situação 9 - Caminhada com pulso regular e palmas simultâneas.}

\section{INSTRUÇÃO}

O coordenador sugere um pulso com um andamento confortável para os jogadores, através de uma contagem de 4 tempos. Ela pode ser feita verbalmente, com estalos ou através de uma outra sonoridade. Na sequência, os jogadores, que estão parados e em círculo, começam a bater os pés no chão de modo uníssono e contínuo, alternando as pernas direita e esquerda. Após este pulso ser estabelecido, o coordenador faz as seguintes instruções: "Estão percebendo este pulso? Um pé depois o outro. Todos juntos! Continuem! Será que é possivel bater uma palma no mesmo momento em que o pé bate no chão? Palma e pé tocam ao mesmo tempo! Batam uma palma cada vez que um dos pés tocarem no chão. Não acelerem!". 


\section{REFLEXÃO MUSICAL E CÊNICA}

É possível perceber, neste momento, que alguém pode ter alguma dificuldade em executar este passo aparentemente simples. Outros podem marcar o mesmo pulso mas subdividindo o tempo, geralmente tocando duas vezes seguidas o mesmo pé. Importante a batida do pé no chão ser firme mas não forte.

\section{Jogo da Flecha}

\section{Situação 1 - Flecha espontânea com palmas, sem pulso e os jogadores em círculo}

\section{APRESENTAÇÃO}

A flecha é um dos jogos mais utilizados e difundidos durante as oficinas de percussão corporal ministradas pelo grupo Barbatuques. Devido à sua empatia lúdica, esta atividade trabalha uma diversidade de capacidades humanas, possuindo diversos desdobramentos e aprofundamentos.

\section{INSTRUÇÃO}

Nesta primeira variação, os jogadores ficam em pé e dispostos em um único círculo, de modo que seja possível todos se enxergarem. O número ideal de participantes, nesta atividade, varia de três a quinze pessoas.

Um dos jogadores inicia o movimento. Ele olha para uma pessoa que está na roda, estabelece um contato visual e, na sequência, bate uma palma em direção a ela. Esta que "recebeu", olha então para um outro jogador (que pode ser inclusive o mesmo que "enviou") e repete o procedimento, mandando sempre uma palma para outra pessoa e assim sucessivamente.

Este primeiro jogo é feito batendo a palma de modo confortável, normalmente com a palma estalada mas pode ser utilizado qualquer um dos timbres ${ }^{41}$, ficando a escolha a critério do coordenador da atividade.

\footnotetext{
${ }^{41}$ Consultar timbres corporais no capítulo 2.
} 


\section{VARIAÇÃO}

Também pode ser pesquisada a variação de intensidade sonora, utilizando palmas mais fortes ou fracas.

\section{REFLEXÃO MUSICAL E CÊNICA}

É possível realizar a flecha em círculo com um maior número de jogadores, entretanto pode haver um aumento da dificuldade, especialmente para aqueles que possui alguma condição especial de visão (miopia, hipermetropia, astigmatismo, etc..), afinal quanto maior o círculo, maior o distanciamento entre os participantes.

Caso exista uma grande quantidade de jogadores, pode-se também dividir a turma e deixar alguns na plateia, como observadores/escutadores. Após um determinado momento, trocam-se as funções.

O primeiro foco a ser percebido, neste jogo, é a comunicação através do olhar ${ }^{42}$. É fundamental o jogador que "envia" a flecha, estabelecer, através do contato visual, uma relação direta com a pessoa que irá recebê-la. Pode ser feita uma reflexão sobre a importância deste tipo de comunicação nas artes do palco. A triangulação visual, técnica aplicada em diversas especialidades teatrais, como a comédia dell'arte, teatro de bonecos e clown, é um grande exemplo da utilização do olhar no fazer cênico. Acontece também quando os atores trocam falas, quando o maestro olha para a orquestra ou até mesmo nas bandas musicais. Neste último caso, é bastante comum os músicos se olharem enquanto tocam, seja para simplesmente compartilhar o prazer de tocar juntos ou para avisar sobre alguma mudança musical, como por exemplo, antes da execução de uma convenção sonora ${ }^{43}$.

Entretanto, no meio musical também é conhecida aquela ocasião em que um músico se distrai ou olha para baixo e não percebe os outros tentando se comunicar. Isso se dá devido a vários fatores, mas um dos mais preocupantes é quando ele já sabe a tocar a música e se acomoda, cristalizando assim a sua execução. A mesma situação pode ocorrer com o ator: depois de muitas temporadas, quando já sabe o texto e as movimentações, ele faz, então, as marcações de forma automática e adestrada. Neste caso, o olhar entre os jogadores, em sua

\footnotetext{
${ }^{42}$ Em relação ao olhar, sempre me recordo da primeira aula que tive no Departamento de Artes Cênicas da USP, com o professor Janô. Ele ministrava a disciplina "Improvisação 1" e, após permenecer em silêncio por longos minutos, observando a turma, lançou a seguinte pergunta: "O olhar é químico?".

${ }^{43}$ O termo "convenção" em música refere-se ao acontecimento de algo diferente do que está sendo executado. Pode ser por exemplo um toque na bateria, uma frase uníssona com instrumentos de sopro, etc.
} 
essência, desperta uma energia cinética bastante interessante, que é capaz de "trazer de volta" a energia deste artista teatral, nesta situação. O oposto também pode acontecer quando o músico está tão envolvido pela música que se entrega a ela. Enquanto toca, olha para cima ou para baixo, geralmente de olhos fechados. Neste caso, sempre coube aos outros músicos a invenção de algum modo para resolver a situação.

O segundo foco é a prontidão de todos para receber a palma. É bastante comum, nos primeiros momentos do jogo, as pessoas estarem de braços cruzados ou com as mãos apoiadas na cintura. Quando recebem a palma, existe um tempo de assimilação, outro tempo de preparação para, somente então, a palma ser enviada. Importante, neste momento, o instrutor salientar a importância do estado de presença, alerta e prontidão ${ }^{44}$, afinal a palma pode chegar ao jogador a qualquer minuto.

Sobre o estado de presença, Pavis diz:

Segundo opinião corrente entre a gente de teatro, a presença seria o bem supremo a ser possuído pelo ator e sentido pelo espectador. A presença estaria ligada a uma comunicação corporal "direta" com o ator que está sendo objeto de percepção (..) Todas estas aproximações têm em comum uma concepção idealista, mística até, do trabalho do ator. Perpetuam, sem explicá-lo, o mito do jogo sagrado, ritual e indefinível do ator (..) Mais do que de presença do ator, poder-se-ia falar do presente contínuo da cena e de sua enunciação (..) O que encontramos no corpo do ator presente nada mais é que nosso próprio corpo: daí nossa perturbação e nosso fascínio diante dessa presença ao mesmo tempo estranha e familiar. (2008. 305)

Complementando, Stenio Mendes também discorre sobre a questão da presença:

No primeiro momento podemos trabalhar a coordenação motora, habilidades, criatividade, desinibição, a pesquisa, trabalhar no estranhamento, libertar-se dos estereótipos, descobrir singularidades, compartilhar suas próprias frases sonoras harmonizando com $\mathrm{o}$

\footnotetext{
${ }^{44}$ Sempre me recordo de uma frase da professora doutora Eudosia Acuña Quinteiro, quando fazia suas aulas de voz, na graduação do Departamento de Artes Cênicas da USP. Ela dizia que o ator deve ter o estado de prontidão e a agilidade de um gato. Este, se estiver dormindo em um profundo estado de relaxamento e, repentinamente, sofrer um grande susto, em milésimos de segundos já estará desperto, alerta e provavelmente, no alto de uma cortina.
} 
coletivo. Num segundo momento colocar esse material em composições, cenas, performances. Num terceiro momento podemos focar no sentido de "presença". O jogo parece que foi inventado para este fim, provocar e o estado de alerta, sentir a presença e isto é explícito nos jogos de improvisação principalmente entre dois jogadores, frente a frente, onde somos assaltados por toda a sorte de inseguranças, de sentir-se desafiado, competindo, em meio a tantos ruídos internos que mal conseguimos escutar a nós mesmos. Só a experiência vai dando a oportunidade de ir relaxando até chegar à brincar com o companheiro e a expressão do jogador se ilumina e a presença com arte é também afetiva, contagia a todos os presentes. (2018, entevista)

\section{Situação 2 - Flecha espontânea com timbres variados, sem pulso e os jogadores em círculo}

\section{APRESENTAÇÃO}

O mesmo jogo anterior porém desta vez, o jogador tem a liberdade de enviar uma outra sonoridades, além das palmas. Existem inúmeras possibilidades, dentre elas batida com o pé no chão, estalos de dedos ou língua, onomatopeias curtas, entre outros.

\section{INSTRUÇÃO}

Ainda em roda, um dos jogadores escolhe um timbre e inicia o jogo. Este mesmo timbre é repassado, sendo usado como flecha. O coordenador deixa fluir o jogo por um tempo até dar um sinal, então a próxima pessoa muda o som e o jogo continua.

Este período entre o mudar de um timbre e outro pode ser variado, inclusive ser estipulado o número de vezes que ele repete. Por exemplo: a cada quatro flechas, muda-se o timbre. Depois a cada três flechas. A cada duas e, por fim, a cada uma. Neste último caso, o resultado fica bastante interessante e musical, pois existirá uma sequência contínua de timbres corporais. 
VARIAÇÃO

Neste jogo, também pode ser explorada a variação de intensidade, utilizando sons mais fortes ou fracos ${ }^{45}$.

\section{REFLEXÃO MUSICAL E CÊNICA}

É de fundamental importância o coordenador propor uma escuta coletiva do que está sendo tocado. Todos têm que perceber que já estão fazendo música.

Caso seja escolhido o som dos pés, os jogadores devem ter uma atenção especial em relação ao ponto de equilíbrio corporal. É bastante comum, ao se usar o som do pé na flecha, que a perna do pé que vai bater no chão avance um pouco, transferindo assim o peso do corpo para frente. Se isto ocorrer, o controle do som ficará comprometido e dependente do ponto de equilíbrio, prejudicando assim a coordenação motora e a precisão sonora. Uma dica é se equilibrar na perna que não fará o som, deixando a outra livre para bater o pé no chão tendo assim um domínio motor mais controlado.

\section{Situação 3 - Flecha espontânea com timbres variados, sem pulso e caminhada pelo espaço.}

\section{INSTRUÇÃO}

Os jogadores, de pé e em círculo, iniciam o jogo anterior e a partir da instrução do coordenador, todos continuam a flecha, só que desta vez, se deslocando, andando pelo espaço.

\section{REFLEXÃO MUSICAL E CÊNICA}

Diferente da caminhada espontânea proposta nos jogos de caminhar, agora existe uma informação a mais. A flecha continua acontecendo sem parar o jogo e o andar já não é o mesmo, afinal está acontecendo uma outra coisa junto. $\mathrm{O}$ olhar torna-se muito mais importante, assim como a atenção deve estar redobrada.

Pode acontecer, durante a caminhada, o caso de alguns jogadores ficarem mais dispersos ou desatentos. É comum neste momento observarmos flechas sendo enviadas para pessoas que não estão prestando atenção na palma. Provavelmente estarão de costas ou olhando para outra direção. Uma das premissas dos jogos é não trabalhar com o conceito de

\footnotetext{
${ }^{45}$ Ver tabela de intensidades pág 64
} 
estar certo ou errado. Entretanto, em uma situação em que um jogador envia uma flecha para outro que está de costas, qual dos dois estaria mais desatento em relação ao jogo? O que mandou a flecha para alguém sabendo que esta pessoa não estava vendo, ou o que estava de costas e não percebeu que mandaram uma palma para ele? Podemos afirmar que a responsabilidade de sustentar o jogo é igual para ambos neste tipo se situação. Eles precisam estar em estado de plena atenção o tempo todo. Importante ter a chamada "visão de 360 graus", termo bastante conhecido pelos artistas teatrais e que sugere um estado de presença e prontidão física e mental no momento em que o jogo está acontecendo.

Um bom exemplo para ilustrar este caso pode ser dito pelo instrutor aos jogadores ao comparar o jogo da flecha com o jogo de futebol, onde a bola cumpre o papel da palma e, neste caso, todos os jogadores estão em campo sempre olhando para a ela, o tempo todo.

O jogo da palma flecha pode ajudar o artista cênico a desenvolver esta capacidade de atenção, prontidão e consciência no seu fazer artístico, tornando-o mais presente em cena.

Outra tendência notada é o caminhar de modo circular. O coordenador também deve estar atento a esta situação, sempre sugerindo que os jogadores se desloquem pelo espaço de jogo de modo a preencher com seus corpos os espaços vazios ${ }^{46}$. Assim, de forma equidistante, o distanciamento físico dos jogadores é distribuído espacialmente de modo mais equilibrado.

\section{Situação 4 - Flecha espontânea com palmas, sem pulso e com os jogadores divididos em dois ou mais círculos}

\section{INSTRUÇÃO}

Os jogadores deverão estar divididos de dois a quatro círculos. É o mesmo jogo anterior e cada grupo inicia o jogo da flecha de forma individual e independente dos demais. A diferença é que, em um determinado momento, o coordenador dá as seguintes instruções:

"Todos conseguem me ouvir enquanto tocam? Não parem o jogo! Conseguem escutar as palmas feitas pelo(s) outro(s) grupo(s)? Tentem perceber estes sons que estão vindo de fora do círculo. Este som diz algo? Consegue perceber a relação deles com a palma feita pelo seu grupo? Agora sem parar de tocar, o desafio de vocês é conseguirem, de alguma

\footnotetext{
${ }^{46}$ Estes espaços não preenchidos são geralmente conhecidos através da expressão "buraco" pelos atores, diretores e artistas da cena. Esta mesma expressão também pode ser utilizada para descrever um momento que ocorre uma quebra de ritmo ou lentidão no desenvolvimento de um espetáculo, parecendo assim um momento sem relevância.
} 
forma, tocar juntos. Toquem juntos! Não é permitido falar nem se comunicar com os outros, a não ser pela flecha. Se escutem! Toquem juntos!".

Durante as instruções, é possível perceber que a tendência natural dos jogadores em tentarem resolver a situação de tocar juntos é justamente estabelecendo um pulso comum entre os círculos. As palmas começam, aos poucos, a serem tocadas ao mesmo tempo. Frequentemente pode ocorrer de um jogador cessar o fluxo da flecha para esperar a palma do outro grupo, tentando assim executar ao mesmo tempo. Caso esta tendência não aconteça, o coordenador pode perceber se instaurou algum padrão ou algum tipo de musicalidade. Após um período, pode ser insinuado para o grupo o estabelecimento de um pulso.

Após a atividade terminar, o instrutor diz: "Foi solicitado para que todos tocassem juntos e o resultado foi este apresentado. Ao dizer [toquem juntos!], seria esta a única maneira possivel? De quantos modos podemos [tocar juntos]?”.

\section{REFLEXÃO MUSICAL E CÊNICA}

É bastante natural, neste processo de estabelecimento do pulso, algum jogador mais pró-ativo tentar, de alguma maneira, solucionar o problema, falando ou marcando um pulso com estalo ou pés, tentando assim reger os demais. Importante o coordenador estar atento para evitar que isto aconteça, afinal um dos objetivos desta situação é justamente a resolução ser feita de modo coletivo.

Importante este momento de reflexão após este exercício. Com esta pergunta "tocar juntos?", os jogadores começam a entrar em contato com a criação coletiva, em que a escuta fica mais acentuada. Este estado de prontidão e escuta é de vital importância tanto nos jogos de improvisação musical quanto teatral. 


\section{Situação 5 - Flecha no tempo com os jogadores em círculo}

\section{INTRODUÇÃO}

Após estas sequências, chegamos nas variações de flecha que utilizam o pulso como base e faz uso dos sons dos pés e das mãos de modo mais aprofundado ${ }^{47}$. Um possível aquecimento para este momento é a situação 9 do Jogo da caminhada ${ }^{48}$.

\section{DESCRIÇÃO}

Dispostos em círculo, os jogadores começam marcando, coletivamente, um pulso regular com os pés para, então, o jogo começar. A flecha tem que ser passada para o outro no exato momento em que o pé bate no chão, ou seja, a palma agora só poderá ser enviada no pulso ou no tempo.

Flecha no pulso (tempo)

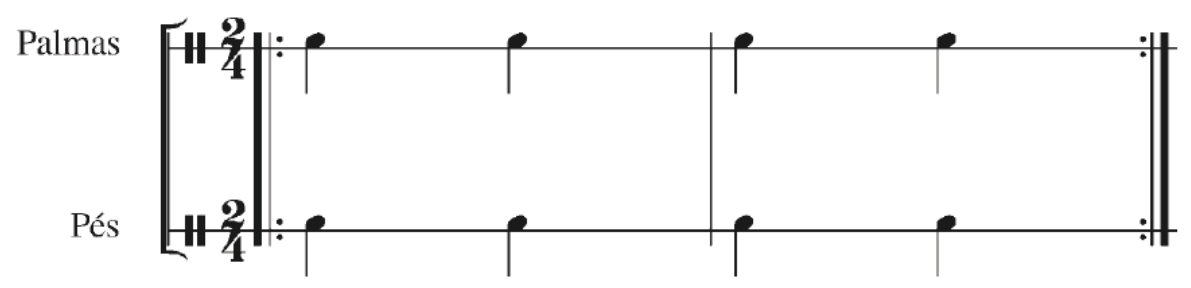

\section{VARIAÇÃO}

Após um período determinado de jogo, o instrutor pode pausar os jogadores e propor outros andamentos, fazendo antes uma nova contagem de tempos. Uma sugestão inicial é ir acelerando o pulso gradualmente. Quanto mais rápido, maior a dificuldade. O ideal é bater uma palma por tempo. Para facilitar, pode existir uma pausa para que o jogador que recebeu a flecha, sem parar de marcar o pulso com os pés, aguarde o momento em que se sinta seguro para lançar a palma. Entretanto, ele não deve se demorar para realizar tal ação.

\footnotetext{
${ }^{47}$ Os pés e mão já estavam sendo utilizados, entretanto, este jogo promove um exercício motor mais elaborado.

${ }^{48}$ Ver pág. 71.
} 
Também, durante o jogo, é possível fazer a pesquisa de intensidades, explorando sons mais fortes ou fracos. Por exemplo, o pé marcando o tempo de uma forma bem suave enquanto a palma tem um volume maior, e vice- versa.

\section{REFLEXÃO MUSICAL E CÊNICA}

É possível perceber, neste momento, que alguém pode ter alguma dificuldade em executar este passo aparentemente simples. Outros podem marcar o mesmo pulso mas subdividindo o tempo, geralmente tocando duas vezes seguidas o mesmo pé. Importante a batida do pé no chão ser firme mas não forte.

Interessante perceber que quanto maior a velocidade, maior a necessidade do estado de alerta e prontidão para receber a flecha. É viável, inclusive, o jogador esperar um pouco pelo momento de bater a palma, deixando, assim, alguns pulsos "vazios", ou seja, sem flecha, apenas com o sons dos pés fazendo a marcação.

Também é possível alterar a intensidade da palma. Existe um fenômeno natural, devido à ansiedade, que, quanto maior a velocidade, maior é a tendência dos jogadores em aumentar o volume, colocando mais força na flecha.

Existe também uma propensão maior em antecipar o som da palma do que atrasar, apesar das duas coisas acontecerem durante o jogo. É imprescindível o coordenador salientar a importância da tranquilidade e da paciência, pois são virtudes fundamentais do fazer musical. O jogador precisa se apropriar da noção temporal. O músico tem que ter controle e domínio sobre o que faz, sobre sua técnica. É de fundamental importância os artistas cênicos terem este domínio consciente da energia e do tônus que empregam durante uma ação física, no caso exemplificado pelo jogo da flecha.

\section{Situação 6 - Flecha no contratempo com os jogadores em círculo}

\section{INTRODUÇÃO}

Uma das definições mais simples sobre o significado de rítmica é o estudo de um pulso regular e sua subdivisões ${ }^{49}$. Entre um pulso e outro, existe um espaço que pode ser

\footnotetext{
${ }^{49}$ Vale lebrar que esta definição de rítmica está se referindo apenas sobre o estudo de um pulso regular.
} 
fracionado matematicamente de diversos modos, sendo que o mais básico deles é quando dividimos o pulso por dois. Este é o contratempo.

Um bom modo de aquecimento, exemplificando corporalmente este conceito, é fazendo o jogo do caminhar alternando pés e mão, especificamente no que diz respeito à variação de um pé e uma palma alternadamente. Os pés estarão marcando o pulso e a palma, batida sozinha entre um pé e outro, pode ser considerada como o contratempo.

\section{DESCRIÇÃO}

É o mesmo jogo anterior só que desta vez os jogadores, em círculo, marcam o pulso com os pés e só podem mandar a palma no contratempo.

Flecha no contratempo

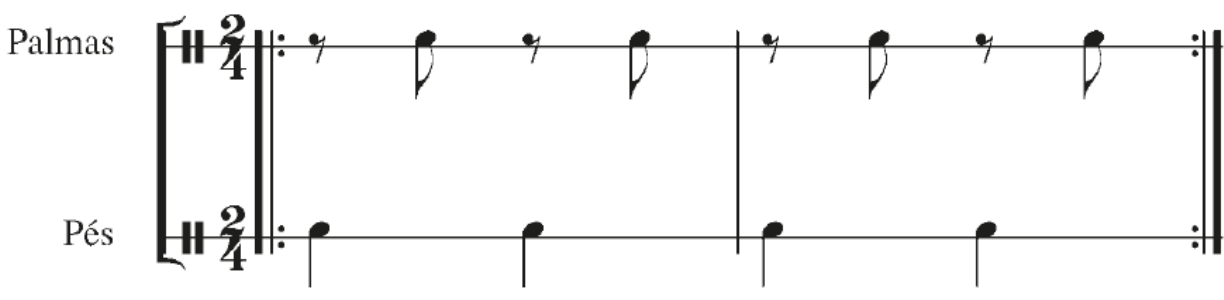

VARIAÇÃO

As mesmas da situação $5^{50}$, podendo alterar andamentos e intensidades.

\section{REFLEXÃO MUSICAL E CÊNICA}

O contratempo pode ser considerado por alguns iniciantes no estudo musical como algo difícil de ser entendido e executado. Uma possibilidade de entender melhor, utilizando o corpo como instrumento, é marcar o pulso com os pés e, logo na sequência, quando formos levantar o outro, fazemos uma ligeira escorregada com a sola do pé para trás. Podemos imaginar este som comparando-o a uma galinha ciscando ou um touro antes de avançar sobre o toureiro.

Outra forma de marcar o contratempo é, ao fazer o pulso com os pés, exagerar no movimento da perna, fazendo com que o joelho suba até a altura da cintura e bata na palmas das mãos, que estarão abertas e voltadas para baixo.

\footnotetext{
${ }^{50}$ Ver pág 78.
} 


\section{Situação 7 - Flecha espontânea no pulso combinando tempo e contratempo}

\section{INTRODUÇÃO}

A partir desta variação, todos os jogos de flecha serão feitos com pulso e os jogadores poderão estar tanto em círculo quanto caminhando no espaço.

\section{DESCRIÇÃO}

Todos iniciam o jogo da flecha, marcando o pulso com os pés. Cada jogador escolhe se palma deve ser enviada no tempo ou no contratempo.

\section{VARIAÇÃO}

Esta atividade pode ser feita em círculo ou caminhando pelo espaço. Também pode trabalhar os diversos andamentos e intensidades.

\section{REFLEXÃO MUSICAL E CÊNICA}

Neste momento, a questão do fazer musical torna-se bastante acentuada e perceptível. Mesmo com os jogadores tendo a liberdade de usar o tempo ou o contratempo livremente, é possível perceber a construção de diversas frases rítmicas no decorrer da atividade. Novamente é importante o coordenador chamar a atenção de todos como criadores rítmicos. A música já está acontecendo durante o jogo.

Caso o jogo seja feito caminhando pelo espaço e/ou acrescentando alterações de velocidade e intensidade, é recomendável perceber se neste momento a questão musical fica em segundo plano.

\section{Situação 8 - Aquecimento para flecha com frases rítmicas (tempo, contratempo e pausa)}

\section{INTRODUÇÃO}

Antes de iniciar os estudos das frases rítmicas passadas por flecha, é possível fazer um treinamento introdutório de sensibilização através de algumas combinações prévias, utilizando tempo, contratempo e pausas. 


\section{DESCRIÇÃO}

Após o pulso ser estabelecido, as flechas serão iniciadas seguindo uma determinada sequência de combinações em que cada uma delas pode ser realizada, sucessivamente, por algum tempo de modo independente ou seguindo a ordem sugerida abaixo. O coordenador faz a contagem inicial de quatro tempos antes da flecha começar. Importante lembrar que os pés nunca param de marcar o tempo, inclusive durante as pausas.

a) Quatro flechas no tempo, quatro pausas, sucessivamente.

b) Quatro flechas no contratempo, quatro pausas, sucessivamente.

c) Quatro flechas no tempo, quatro flechas no contratempo, quatro pausas, sucessivamente.

d) Quatro flechas no tempo, quatro flechas no contratempo, sucessivamente.

e) Três flechas no tempo, três pausas, sucessivamente.

f) Três flechas no contratempo, três pausas, sucessivamente.

g) Três flechas no tempo, três flechas no contratempo, três pausas, sucessivamente.

h) Três flechas no tempo, três flechas no contratempo, sucessivamente.

i) Duas flechas no tempo, duas pausas, sucessivamente.

j) Duas flechas no contratempo, duas pausas, sucessivamente.

k) Duas flechas no tempo, duas flechas no contratempo, duas pausas, sucessivamente.

1) Duas flechas no tempo, duas flechas no contratempo, sucessivamente.

m) Uma flecha no tempo, uma pausa, sucessivamente.

n) Uma flecha no contratempo, uma pausa, sucessivamente.

o) Uma flecha no tempo, uma flecha no contratempo, uma pausa, sucessivamente.

p) Uma flecha no tempo, uma flecha no contratempo, sucessivamente.

Além de seguir a ordem acima, é possível escolher apenas uma das combinações para praticar. É possível também alterar a ordem apresentada, intercalando ou suprimindo combinações podendo inclusive aumentar o número de palmas e pausas, por exemplo: 
1) Sete flechas no tempo, sete flechas no contratempo, sete pausas, sucessivamente

2) Dez flechas no tempo, dez flechas no contratempo, sucessivamente

\section{VARIAÇÃO}

Esta atividade pode ser feita em círculo ou caminhando pelo espaço, além de poder variar a velocidade e a intensidade.

Também é possível fazer diversas combinações entre o número de palmas no tempo, no contratempo e nas pausas. Exemplos:

a) Quatro flechas no tempo, duas flechas no contratempo, duas pausas, sucessivamente.

b) Três flechas no tempo, cinco flechas no contratempo, sucessivamente

c) Três flechas no contratempo, três pausas, duas flechas no tempo, três pausas, sucessivamente

\section{REFLEXÃO MUSICAL E CÊNICA}

Com o aumento das dificuldades, é bastante comum reparar também no aumento da concentração e, consequentemente, da tensão dos jogadores. Este fator pode ser traduzido em palmas mais fortes ou incômodos corporais. O jogo, neste ponto, tem a tendência de se tornar mais racional e a musicalidade pode ficar em segundo plano. Importante o instrutor deixar os jogadores cientes desta tendência para assim, não perderem o foco da atenção, da concentração e da escuta coletiva.

\section{Situação 9 - Flecha com frases rítmicas}

\section{INTRODUÇÃO}

Durante os jogos de flecha envolvendo um pulso regular, foi possível perceber a existência de uma grande variedade de combinações rítmicas. Conforme explicado anteriormente, um das definições de rítmica é o estudo dos ordenamentos de pulsos e suas subdivisões $^{51}$.

\footnotetext{
${ }^{51}$ Esta definição é em relação aos pulsos regulares.
} 
Até então, não foi utilizado o conceito de compasso, que é a união de dois ou mais pulsos regulares, em agrupamentos cíclicos que se repetem. A contagem até quatro feita pelo coordenador antes da flecha tinha dois objetivos básicos: marcar tanto a velocidade do andamento quanto o momento de iniciar o jogo. A partir de agora, este momento terá como função marcar, também, qual o compasso que a frase musical terá. Será abordado neste caso, o compasso quaternário (quatro pulsos que vão se repetindo).

\section{DESCRIÇÃO}

O coordenador propõe um pulso com os pés e, na sequência, todos entram juntos, do mesmo modo. Ele demonstra para o grupo, através dos sons de palma, a frase rítmica que será passada em flecha. Os jogadores primeiro escutam, esperam o sinal do coordenador para, só então, reproduzir, de forma uníssona, a mesma frase sugerida. Ela também será feita com palmas por todos enquanto o pulso é marcado com os pés. No momento que os jogadores aprenderem a sequência, o coordenador pede, então, para que cessem as palmas, deixando somente os pés marcando, e dá o sinal de início, para a frase ser enviada em flecha. No exemplo abaixo, a frase tem a duração de quatro tempos e está repetida duas vezes para um melhor entendimento.

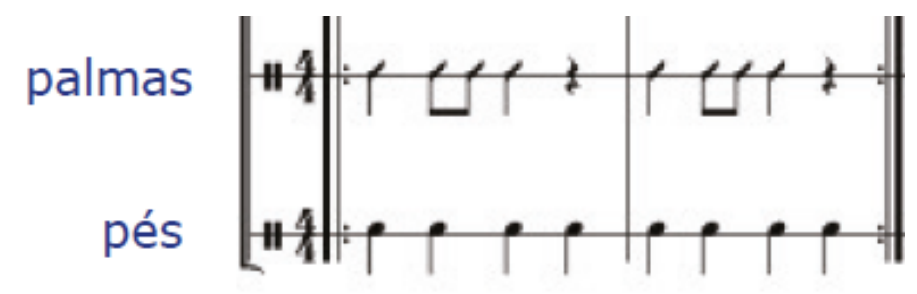

\section{VARIAÇÃO}

Existem inúmeras possibilidades de frases rítmicas que podem ser passadas por flecha, utilizando as mais diversas subdivisões rítmicas.

O criador do Barbatuques, Fernando Barba, inventou duas flechas, uma chamada "Tum Pá" e a outra "Pá Tum", em alusão ao som grave emitido pelo pé (Tum) e agudo pela palma (Pá). Nesta composição, cada compasso está utilizando somente dois pulsos. Neste caso, também utilizou-se a semicolcheia para compor a frase, ou seja, uma subdivisão rítmica que divide o pulso em quatro tempos. Abaixo, segue o exemplo de cada uma delas, lembrando que estão sendo escritas duas vezes seguidas para uma melhor compreensão. 
Flecha "Tum Pá"

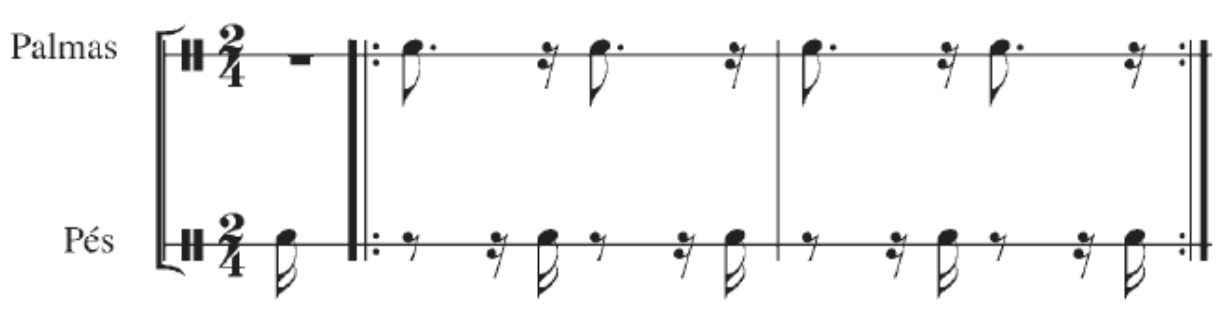

Flecha "Pá Tum"

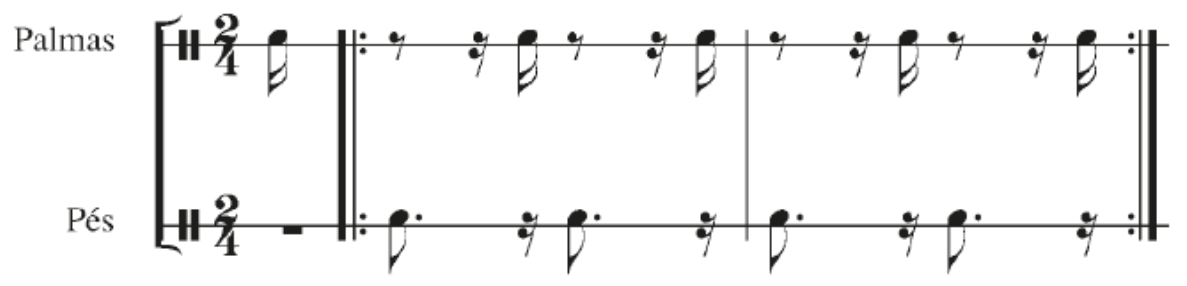

É possível alternar consecutivamente estas flechas: Tum Pá, Pá Tum, Tum Pá, Pá Tum.. Teremos uma resultante parecida com o ritmo do samba.

\section{REFLEXÃO MUSICAL E CÊNICA}

Este é um momento bastante importante. Podemos perceber como neste ponto, o jogo torna-se bem mais racional devido à necessidade de uma coordenação motora mais apurada e controlada por parte do jogador. No começo pode ser bem difícil estabelecer coletivamente a frase rítmica de forma fluida.

Um dos momentos mais preciosos desta atividade é quando um dos jogadores, durante a execução da frase, tenta "salvar" a flecha, batendo a palma em um lugar diferente do combinado mas permanecendo consciente da frase rítmica, não interrompendo assim o fluxo do jogo. O movimento corporal que o jogador faz ao tentar "salvar" a flecha geralmente é percebido por todos. Ele perde o pulso no corpo mas o continua sentindo, seja interiormente ou percebendo através dos outros jogadores. Esta hora é de grande aprendizado para o domínio técnico da musicalidade, pois se revela como uma ação fora de um padrão esperado mas que continua contribuindo no desenvolvimento do jogo, não deixando o pulso, o ritmo e a fluência quebrarem. Este estado de presença é fundamental especialmente nos estilos de teatro que utlizam a linguagem da improvisação, pois é um grande apurador de sensibilidade. Os atores devem estar atentos a tudo durante o tempo todo. É um momento bastante 
interessante porque podemos perceber uma virada no que vinha sendo proposto até então. Conforme diz o dito popular, é aprender a "consertar o avião enquanto ele está voando", ou seja, esta situação se torna um ótimo treino para preparar um artista teatral mais consciente e com mais domínio de suas ações enquanto estiver em cena. Ele estará mais apto a saber lidar de forma mais consciente com questões externas que por ventura, possam vir a ocorrer durante sua apresentação no palco.

\section{Jogos de flecha e os três centros sonoros}

Todos os jogos de flecha com pulso regular apresentados até aqui utilizaram os pés para marcar o pulso e as mãos para fazer a frase musical, desconsiderando assim o centro sonoro da boca.

Entretanto é possível refazer todas as sequências e variações descritas até então, alternando o local do corpo em que será marcado o pulso e passado a flecha. Ela pode ser passada pelo pé enquanto todos batem as palmas no pulso.

\section{Dissociação pés x mãos x boca}

\section{Situação 1 - Inversões de pulso com frase rítmica utilizando dois centros sonoros}

\section{INTRODUÇÃO}

Desde que o ser humano tornou-se bípede, aprendeu, de forma natural, a marcar um pulso nos pés enquanto caminha, podendo, inclusive, bater palmas e cantar, simultaneamente. De natureza igual, desde que ele aprendeu a cantar "Parabéns a Você", assimilou corporalmente, muitas vêzes de modo intuitivo, que é relativamente simples cantar enquanto marca um pulso regular ${ }^{52}$ com as palmas. Desta forma, um som produzido pela boca está fazendo a frase rítmica.

Estas combinações entre os três centros sonoros através do caminhar, bater palmas e cantar, sempre existiram nas mais diversas culturas e civilizações, seja de modo espontâneo, intuitivo ou elaborado. Geralmente não causam muitas dificuldades quando são executadas

\footnotetext{
${ }^{52}$ Na música "Parabéns a Você" (de autoria de duas irmãs professoras norte-americanas, que tinham uma pequena escola em casa, nos EUA), além de marcar um pulso regular, normalmente aceleramos o pulso na segunda parte.
} 
nos jogos de rítmica. Entretanto, podemos aprofundar o uso delas, simplesmente invertendo as funções em cada um dos centros.

É possível perceber, neste caso, que utilizamos dois centros sonoros de modo simultâneo em três situações distintas: duas em que os pés marcam o pulso para as mãos ou para a boca, e uma na qual as palmas marcam o pulso para a boca.

1) Pés marcando o pulso e as mãos fazendo a frase sonora. Invertendo as funções:

Mãos marcando o pulso e os pés fazendo a frase sonora.

2) Mãos marcando o pulso e a boca fazendo a frase sonora. Invertendo as funções:

Boca marcando o pulso e as mãos fazendo a frase sonora.

3) Pés marcando o pulso e a boca fazendo a frase sonora. Invertendo as funções: Boca marcando o pulso e os pés fazendo a frase sonora.

Cada uma das três combinações pode ser realizada de dois modos distintos quando invertemos a função de cada centro sonoro.

Mesmo existindo algumas dificuldades, o primeiro modo já faz parte da natureza humana, conforme visto acima. Existe uma maior predisposição de assimilação pelos jogadores. Contudo, isto já não é tão frequentemente observado no segundo caso quando, ao inverter as funções, a dificuldade motora aumenta, necessitando uma maior concentração, raciocínio e tempo de treinamento para se realizar os movimentos propostos.

\section{DESCRIÇÃO}

Em círculo, o coordenador começa marcando um pulso com os pés e todos o acompanham da mesma forma. Sem parar os pés, faz com as palmas uma frase rítmica que terá a duração de quatro tempos. Todos os jogadores repetem a frase após escutá-la por

algumas vezes. É possível recomeçar a sequência de modo encadeado ou para uma maior assimilação, fazer uma pausa de quatro tempos, cada vez que a frase é executada, . 

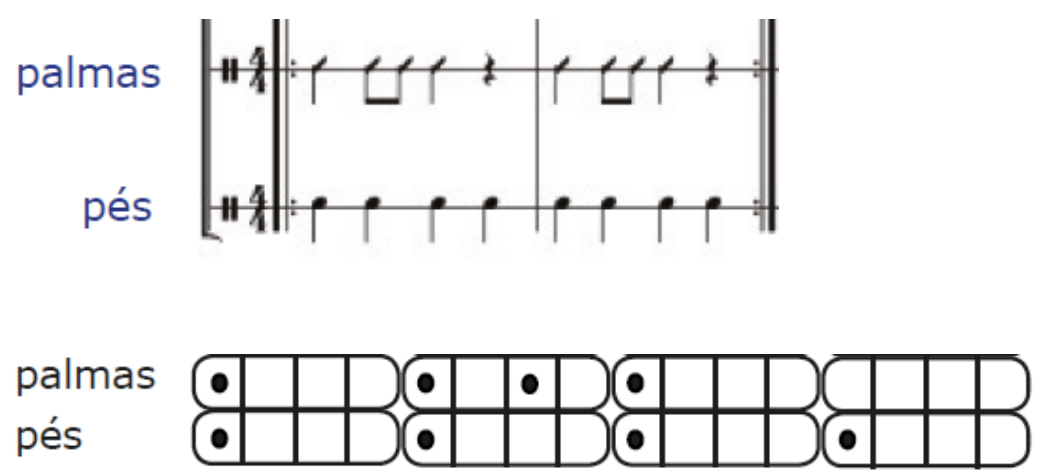

Após todos aprenderem, o coordenador interrompe o movimento e propõe as seguintes sequências:

1) A frase é feita somente com palmas, sem marcar o pulso com os pés.

2) A mesma frase é feita somente com os pés.

3) O pulso é marcado somente com as palmas.

4) A frase rítmica é feita com os pés enquanto o pulso é marcado com as palmas.

Todas estas sequências devem ser estudadas e aplicadas em todas as três combinações (pés/mãos, mãos/boca e pés/boca). O quadro abaixo mostra estas possibilidades, utilizando a mesma frase musical dos exemplos acima. 
Figura 24: Coordenação Pés/Mãos/Voz

Coordenação Pés / Mãos/ Voz

Este exercicio explora a independêncla rítmica entre membros de nosso cixo corporal (cabeça, măos e pés). Uma parte do corpo executará uma frase musical enquanto outra parte marcará a pulsaçăo.

1

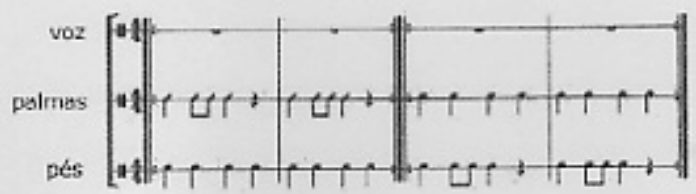

2
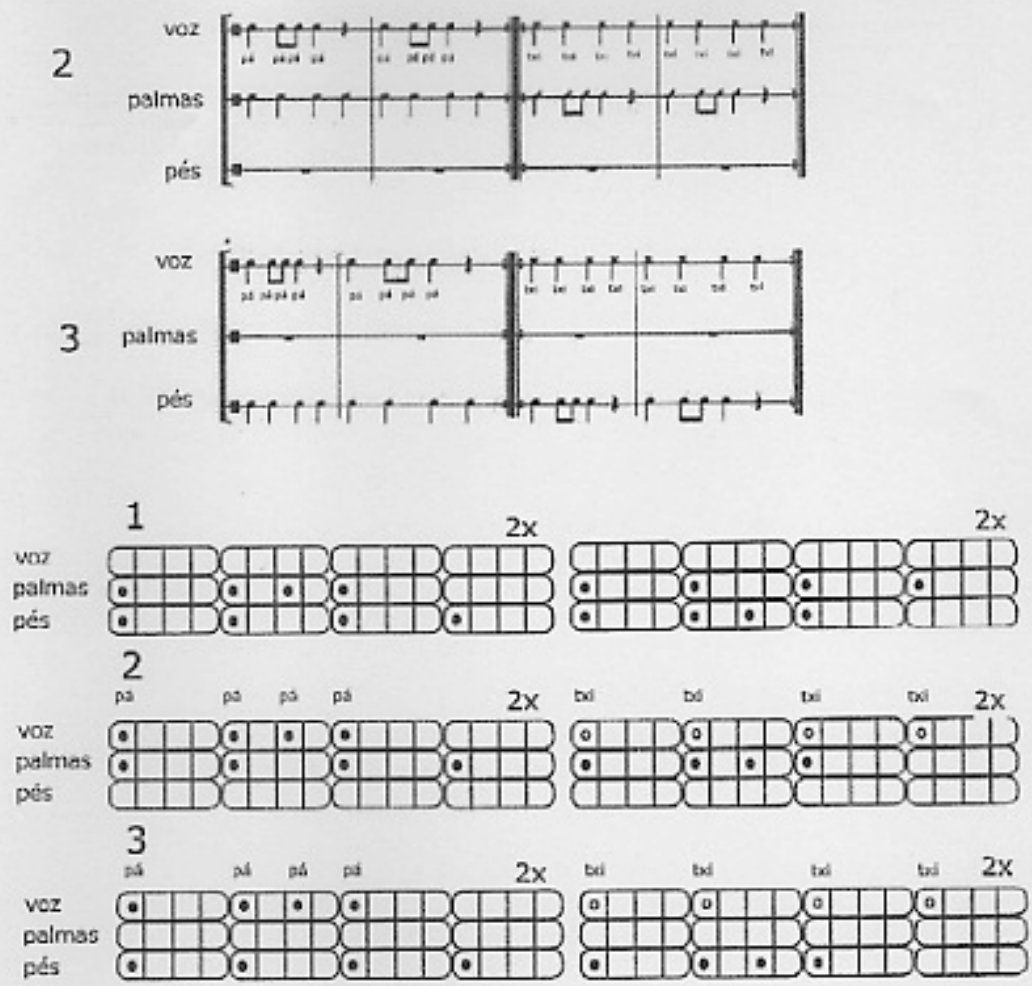
Importante notar que nos exemplos acima, quando se faz uso do centro sonoro da boca, a sílaba "pá" é utilizada para a frase rítmica e a sonoridade "txi" para marcar o pulso.

\section{VARIAÇÃO}

É possível executar estas sequências através de uma infinidade de frases rítmicas. A utilizada, no exemplo acima, é composta somente por tempo e contratempo dentro de um compasso de quatro pulsos. Podemos utilizar outras subdivisões rítmicas, como tercinas, semicolcheias (que dividem o pulso por três e quatro, respectivamente) e compassos com variados pulsos. O andamento também pode ser alterado. Neste caso, vale ressaltar que o aumento da velocidade pode ampliar as dificuldades de execução.

Para uma maior concentração dos jogadores é recomendado fazer este jogo em círculo. A atividade pode ser feita caminhando somente durante os momentos em que os pés são utilizados, seja marcando o pulso ou fazendo a frase rítmica.

\section{REFLEXÃO MUSICAL E CÊNICA}

Busca-se, nas artes da cena, um artista que tenha domínio sobre o seu corpo e sua movimentação, para comunicar, de forma plena, o que está querendo expressar. Um dos exemplos mais citados no mundo teatral é o caso de um ator que, ao atuar, parece ter a voz "descolada" do resto do corpo ou de sua expressão facial. Quando um músico toca um instrumento de forma plena, podemos perceber que todo o seu corpo está em concordância com a ação que está fazendo ${ }^{53}$. É possível observarmos esta plenitude corporal, desde o primeiro violinista da orquestra ao guitarrista da banda de heavy-metal, quando estão tocando em um concerto ou show.

Refletindo sobre os três centros sonoros e suas relações interdependentes, pode-se estabelecer um paralelo importante com o treinamento do artista cênico, pois mostra-se de grande valia para o estudo de um corpo expressivo mais integrado e coeso.

\footnotetext{
${ }^{53} \mathrm{O}$ exemplo no texto foi dado apenas para ilustrar uma determinanda imagem que é comum de acontecer, entretanto isso não deve ser tomado como verdade absoluta. Vale lembrar que em algumas escolas interpretativas tradicionais, o intérprete não devia se mover nem expressar-se com a face, etc. A exigência era ser capaz de expressar as intenções do compositor apenas pelo sonoro. Entretanto, em alguns estudos de música contemporânea, podemos contradizer esta afirmação. Meu orientador, Prof. Dr. Fábio Cintra, ao ministrar aulas no Departamento de Música (ECA-USP), pode experimentar com os alunos diversas possibilidades performáticas corporais durante a execução de uma música contemporânea. Este mesmo estudo vale para muitas poéticas cênicas contemporâneas, que desconstroem ou relativizam a relação de concordância entre corpo e ação.
} 


\section{JOGOS DE COMPOSIÇÃO, REGÊNCIA E IMPROVISAÇÃO}

\section{Jogo do Eco}

\section{INTRODUÇÃO}

O jogo tem este nome lúdico porque trabalha com o princípio da imitação defasada. Diferente de um espelho, onde o reflexo da imagem volta para os nossos olhos de maneira praticamente instantânea, o eco precisa de um determinado tempo para retornar. Existe uma pausa entre a emissão e a reverberação sonora.

O som que regressa continua com as mesmas características de quando foi inicialmente projetado.

\section{DESCRIÇÃO}

Todos os participantes estão posicionados em um círculo. Seguindo a ordem da roda, no sentido horário ou anti-horário, um jogador de cada vez cria uma frase sonora, encadeando alguns timbres corporais. Os demais escutam, em silêncio, e assim que a frase for concluída, tentam, ao mesmo tempo e de forma uníssona, imitar a frase com a maior fidelidade sonora possível. É importante a pessoa, que criou a frase, também ser capaz de reproduzir o que acabou de fazer, evitando assim combinações muito complexas ou aleatórias.

As reproduções também podem ir além do campo sonoro e serem feitas sobre as movimentações, expressões e trejeitos corporais de quem está propondo a frase.

\section{VARIAÇÃO}

Em um primeiro momento, não é necessária a existência de um pulso. Com o decorrer do jogo, é possível introduzir andamentos. As frases podem ser feitas tanto seguindo de modo livre a marcação de um pulso quanto dentro de um compasso, neste caso, estipulado pelo coordenador. Por exemplo, quatro pulsos para a frase ser feita e consequentemente outros quatros para ser repetida, assim sucessivamente.

O jogo do eco também pode ser feito de forma temática. Em uma rodada, só podem ser feitas combinações usando timbres de determinado centro sonoro ou também sons específicos, como somente tipos de palmas, melodias vocais ou imitação de instrumentos, para exemplificar. 


\section{REFLEXÃO MUSICAL E CÊNICA}

A partir de agora, a figura do jogador-compositor entra em cena, mesmo que inicialmente de modo individual. Esta função é diferente do que foi visto até aqui, em que os jogadores eram reprodutores sonoros. Este jogo trabalha com as duas possibilidades.

Podemos comparar cada timbre corporal a uma "letra" do alfabeto. O objetivo deste jogo é criar novas "palavras", ou seja, agora temos um estudo de composição sonora.

\section{Refrão-Improviso}

\section{DESCRIÇÃO}

Em círculo, o coordenador apresenta, para os jogadores, uma frase musical com duração de quatro pulsos. Em seguida, sem interromper o fluxo rítmico, marca outros quatros pulsos utilizando somente estalos de dedos. A sequência é novamente reiniciada.

Como exemplo, será utilizada a seguinte combinação de pés e palmas seguido de estalos:
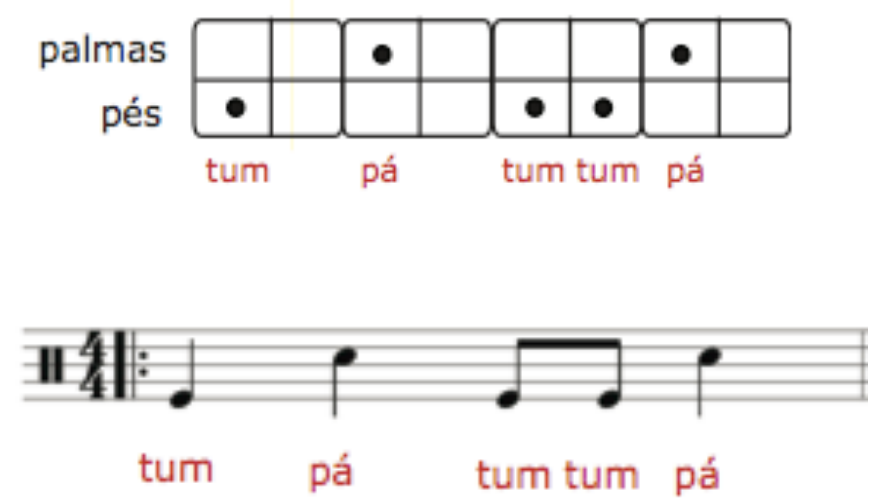

Os jogadores repetem a sequência, em uníssono, por algumas vezes. Após assimilarem a frase, um de cada vez, seguindo a ordem na roda (sentido horário ou anti horário), fará um improviso livre utilizando sons corporais durante o momento dos quatro estalos. Importante ressaltar que enquanto o jogador faz seu solo, os demais continuam a marcar o pulso estalando os dedos suavemente. Assim que terminarem os quatro tempos, todos voltam a executar a frase de refrão, inclusive o solista. 


\section{VARIAÇÃO}

Existem uma infinidade de frases musicais que podem ser utilizadas como refrão. Estas, por sua vez, podem ser multiplicadas ainda mais, diversificando os timbres corporais

Do mesmo modo, também podemos aumentar ou diminuir a quantidade de pulsos, lembrando, neste caso, que o tempo do solo continuará sendo proporcional ao tamanho da frase.

Existem diversas variações durante o momento de solo, dentre elas:

- Refrão de quatro tempos. Em seguida, dois jogadores, que estão lado a lado, improvisam, individualmente, onde cada um utilizará somente dois tempos. Volta refrão.

- Refrão de oito tempos. Em seguida, quatro jogadores, que estão lado a lado, vão improvisar da seguinte forma: jogador 1 improvisa em dois tempos, jogador 2 improvisa em dois tempos, jogador 3 imita o improviso do jogador 1 e jogador 4 imita o improviso do jogador 2. Volta refrão.

- Refrão de quatro tempos. Em seguida, dois jogadores, que estão lado a lado, improvisam ao mesmo tempo uma "conversa musical". Volta refrão.

- Refrão de quatro tempos. Em seguida, quatro jogadores, que estão lado a lado, improvisam coletivamente. Volta refrão.

- Refrão de quatro tempos. Em seguida, todos os jogadores improvisam coletivamente. Volta refrão.

- Refrão de quatro tempos. Em seguida, todos os jogadores fazem silêncio absoluto. Volta refrão.

- Refrão de quatro tempos. Em seguida, todos os jogadores, desta vez de olhos fechados, fazem silêncio absoluto. Volta refrão.

\section{REFLEXÃO MUSICAL E CÊNICA}

Podemos perceber, na estrutura deste jogo, a mesma relação existente entre coro e corifeu.

Quando existir o improviso em duplas, podemos começar a por em prática a tríade de improvisação criada por Theophil Meier e difundida por Stenio Mendes: ouvir o outro, sentir o outro e manter o outro. 
Este conceito de improvisação musical estabelece que primeiramente o jogador deve ouvir o outro, ou seja, simplesmente estar aberto a receber este estímulo sonoro que vem de fora. Perceber e estar atento a estas ondas sonoras que chegam é puramente um ato físico. Neste caso, seus canais de percepção e recepção são ampliados.

Ao sentir o outro, existe então uma sensibilização sobre este som que chega em seus ouvidos. O receptor deve tentar perceber o que este som quer dizer, que qualidades possui, se existe alguma identificação com seu corpo, sua mente ou com algum sentimento e emoção. Deve também estar aberto a perceber se este som traz alguma ideia ou imagem.

Após ouvir e sentir, o improvisador deverá ajudar a manter o outro, ou seja, dar suporte a esta sonoridade proposta pelo outro. Nesta etapa, o receptor se deixa contagiar, acrescentando assim uma sonoridade que se harmonize de alguma forma com estes sons que chegam.

Importante perceber que em todo este processo acontece de modo simultâneo. Os dois jogadores estarão ouvindo, sentindo e mantendo o outro ao mesmo tempo.

\begin{abstract}
No caso da improvisação com a música corporal, o mais importante é praticar numa sequência de jogos a premissa básica: "ouvir o outro, sentir o outro e manter o outro" que me foi transmitida por um professor alemão que passou pelo Brasil nos anos 80, também cantor e ator, de nome Theophil Maier. $\mathrm{O}$ exercício que inaugurou esta atividade também vem do mestre Theophil, consiste uma sequência de quatro fases, quatro movimentos, inicia-se com sopros, percussão suave, depois na segunda fase percussão mais forte, na sequência surge a percussão vocalizada que incluía a blablação e por fim, no quarto movimento só vogais e cantorias. Este exercício também marcava o ritual de iniciação, apagavam-se as luzes, com muito silêncio pra começar e terminar. (Entrevista concedida por Stenio Mendes, julho de 2018)
\end{abstract}

No caso deste jogo, onde existe um improviso em dupla, todo este caminho acontece de modo muito rápido. Do mesmo modo que ocorre em um diálogo, esta conversa musical pode acontecer de diversas formas. É possível um jogador "falar" mais que o outro, ambos falarem sem se escutar ou alguém impor sua sonoridade através de um volume mais alto. Importante todos estarem atentos sobre estas possibilidades e tentarem buscar uma harmonização em cima destes três pilares de improviso. 
Em todos os jogos que utilizarem de alguma forma a improvisação e a criação coletiva, o ouvir, sentir e manter o outro deve ser a principal regra a ser seguida pelos jogadores.

\section{Carrossel (jogo do Maestro)}

\section{DESCRIÇÃO}

Os jogadores são divididos em três grupos, cada qual com, aproximadamente, o mesmo número de participantes. Cada um destes conjuntos deve assumir a forma de um grupo coral e devem estar dispostos em círculo e voltados para o centro.

O coordenador fica posicionado no centro do círculo. Ele inicia o jogo assumindo o papel de maestro, estabelecendo, primeiro, uma relação visual com os grupos. Ele escolhe um estímulo sonoro e lança para um dos grupos que, através da imitação, o reproduz de forma continuada. Na sequência, faz o mesmo com os demais, propondo sonoridades distintas para cada grupo mas que, de alguma forma, estejam interligadas musicalmente. Com o decorrer do jogo, o maestro vai propondo outras combinações sonoras para cada grupo, através de sinais de regência ${ }^{54}$, criando assim, diversas possibilidades musicais. Importante o maestro conseguir estabelecer uma comunicação clara com todos, sem utilizar a voz, somente pelo gestual.

\section{VARIAÇÃO}

Agora cada grupo terá o seu próprio regente. Um integrante de cada agrupamento se situa na frente dos demais. Cada maestro deve reger seu próprio grupo de acordo com os sinais de regência. Importante ele estar atento às sonoridades que estão acontecendo para criar, naquele momento, algo que dialogue de alguma forma com os demais. É um jogo de criação coletiva.

Um exercício criado por Fernando Barba, chamado Carrossel, onde se institui 4 grupos e cada grupo vai representar um coro, e cada coro terá seu próprio regente que vai criar, improvisar um mote para ser executado pelo seu coro, de forma que se formarão quatro grupos com 4 regentes e seus coros soando ao mesmo tempo e terão de se harmonizar, cada um com frases

\footnotetext{
${ }^{54}$ Consultar anexo.
} 
melódicas, percussivas. Na continuidade seus regentes também vão se alternando até que todos possam propor suas próprias invenções sonoras ao seu grupo. Neste mesmo jogo, agora proposto para os estudantes de teatro, houve desdobramentos inesperados. De repente cada coro se deslocou do espaço pré fixado e ocupando toda a área da sala, se transformou em quatro grupos musicais dançantes, criando coreografias, interagindo cenicamente uns com os outros grupos. O que para mim foi mágico, para eles foi natural... $\mathrm{Na}$ sequência numa outra proposta, criamos quatro grupos atores. Partindo com a música corporal, eles saíram da sala de aula, cada grupo com seu coro improvisado, foram caminhando e dançando. de repente surgia uma pausa então eles se lançavam cenicamente, interagindo com espaços, objetos, ressignificando-os poeticamente criando várias cenas curtas. Observando a desenvoltura desses seres atuando e a incrível disponibilidade para brincar com o teatro testemunho o quão libertadora é a convivência de músicos e os atores trabalhando juntos, como imagino também, junto às outras áreas artísticas. (Entrevista concedida por Stenio Mendes, julho de 2018)

\section{Sequência Minimal}

\section{INTRODUÇÃO}

É um jogo de criação coletiva feito de forma sequencial. O nome faz uma alusão ao minimalismo musical. Este movimento trabalha com a ideia da repetição de um determinado ciclo musical por longos períodos de tempo, podendo ocorrer algumas pequenas variações, chegando a criar sensações mântricas e quase hipnóticas.

\section{DESCRIÇÃO}

Em um círculo de pessoas, o coordenador inicia o jogo lançando um estímulo musical que pode ser feito com quaisquer timbres corporais. Esta frase precisa estar em um pulso regular e, preferencialmente, seguindo um determinado compasso. Sem interromper a sonoridade, ele repete a frase de forma continuada. Seguindo a roda no sentido horário ou anti-horário, a pessoa que está ao seu lado escuta o que foi feito e, em seguida, cria outro som que, de alguma maneira, complemente ou combine o que foi sugerido. O próximo jogador ouve a nova combinação, acrescenta outro som, e assim sucessivamente. Após todos os jogadores entrarem, o coordenador propõe um determinado tempo de escuta da somatória sonora e, em seguida, se silencia. O segundo jogador que tinha entrado, também se silencia após um pequeno instante, e assim sucessivamente, até que a última pessoa da roda fique 
sozinha tocando até se silenciar também. A música criada começa de um jeito, se expande e termina de outro.

VARIAÇÃO

Uma possível variação é que, ao invés de ir silenciando um a um após todos entrarem, um jogador maestro caminha até o centro da roda para reger os demais.

\section{Contágio Livre (Improvisão)}

\section{INTRODUÇÃO}

O título do jogo sugere a ideia de um jogador ser contagiado livremente pelo som que o outro emite. Por isso o nome improvisão, afinal, seria um grande improviso praticado pelos jogadores.

\section{DESCRIÇÃO}

Todos os jogadores se sentam em um círculo de maneira próxima ou preenchendo o centro da sala. Para um melhor aprofundamento, é recomendado apagar a luz ou fazer o jogo de olhos fechados. Todos devem permanecer em silêncio nos primeiros instantes do jogo. Aos pouco, a sonoridades vão sendo iniciadas sem uma ordem predeterminada. O foco principal está nos três princípios de Theophil: ouvir o outro, sentir o outro e manter o outro.

\section{VARIAÇÃO}

É possível estabelecer uma ordem de sugestões. Silêncio, ventos, floresta, vozes, nota pedal, cantos, silêncio.

\section{REFLEXÃO MUSICAL E CÊNICA}

Conforme visto anteriormente, aqui a regra dos três pilares de improvisação (ouvir, sentir e manter) continua sendo a principal a ser seguida. 


\section{JOGOS TEATRAIS MUSICAIS}

\section{Flecha rítmica com palavras e textos}

\section{DESCRIÇÃO}

São as mesmas instruções do jogo da flecha ${ }^{55}$, entretanto o som emitido é substituído inicialmente por uma palavra. Os jogadores podem, aos poucos, tentar formar frases, em que cada flecha pode ser uma palavra ou uma pequena frase.

\section{VARIAÇÃO}

Podemos alterar a velocidade e a intensidade com que a flecha é enviada, além de fazer a atividade em círculo ou caminhando pelo espaço.

\section{Jogo do Espelho (som e movimento)}

\section{DESCRIÇÃO}

O jogo é feito em dupla. Antes de iniciar, os jogadores decidem, entre si, quem faz o som e quem faz o movimento. Seguem as sequências:

- Jogador 1 se movimenta e jogador 2 sonoriza esta movimentação.

- Jogador 1 se movimenta de acordo com os sons propostos pelo jogador 2.

- "Siga o seguidor!".

Agora os jogadores repetem a sequência, invertendo as funções.

\section{VARIAÇÃO}

Este jogo pode ser feito por várias duplas ao mesmo tempo e, em algum momento, o coordenador pode pedir para que todos, sem sair do lugar, dêem uma pausa para assistir uma determinada dupla.

Outra possibilidade é a de duas duplas trabalharem juntas. Os dois jogadores responsáveis pelos movimentos podem estabelecer uma relação cênica amparados pelos

\footnotetext{
${ }^{55}$ Consultar jogos de flecha pág. 72
} 
outros dois jogadores encarregados pela sonorização. Podem ser feitas as sequências vistas acima.

\section{REFLEXÃO MUSICAL E CÊNICA}

Tanto a sonoplastia quanto a trilha sonora são possíveis de serem utilizadas para ilustrarem os movimentos. A sonoplastia está mais ligadas a sons naturais e ações físicas, como o barulho do sapato ao andar, o ranger de uma porta ou um galo cantando. A trilha sonora pode estar ligada mais a um clima, uma música composta ou efeitos sonoros que não existem de forma natural.

\section{Jogo da Engrenagem Sonora}

\section{INTRODUÇÃO}

Batizado de "Máquina Rítmica" pelo teatrólogo brasileiro Augusto Boal em sua metodologia do Teatro do Oprimido, este jogo é bastante popular nas escolas e oficinas de teatro. Unifica, de forma simples e lúdica, elementos teatrais e musicais durante a sua realização.

\section{DESCRIÇÃO}

De acordo com as instruções de Boal:

Um ator vai ao centro e imagina ser uma peça da engrenagem de uma máquina complexa. Faz um movimento rítmico com seu corpo e, ao mesmo tempo, o som que esta peça da máquina deve produzir. Os outros atores prestam atenção. Um segundo, com seu próprio corpo, acrescenta uma segunda peça à engrenagem dessa máquina, com outro som e outro movimento que sejam complementares e não-idênticos aquele feito pelo primeiro ator. Um terceiro ator faz o mesmo e depois um quarto, até que todo o grupo esteja integrado em uma mesma máquina, múltipla, complexa e harmônica"(2008, p. 129)

\section{VARIAÇÃO}

Este jogo pode ser aprofundado em relação às suas possibilidades musicais corporais. 


\section{Jogo da Paisagem Sonora}

\section{INTRODUÇÃO}

Os termos Onde, Quem e O Quê são utilizados para denominar e descrever diversos jogos elaborados por Viola Spolin. Estes termos são, respectivamente, associados ao "cenário/ambiente", "personagem/relacionamento" e "ação de cena". Por possuírem uma característica ampla e neutra, são bastante proveitosos nos jogos de improvisação .

Em relação ao termo Onde, um cenário ou ambiente pode ser estabelecido de diversas maneiras, geralmente através de um cenário ou adereço de cena. Entretanto, é perfeitamente possível estabelecer este local através dos sons que ali se encontram.

O termo "paisagem sonora" foi citado e estudado, pela primeira vez, por Murray Schafer. De acordo com ele, paisagem sonora é qualquer campo de estudo acústico. Tendo sua origem na palavra inglesa "soundscape", também propõe uma análise sobre os sons que rodeiam o ser humano em determinado ambiente.

O jogo da paisagem sonora pretende trabalhar com a possibilidade de criação e reprodução das características acústicas de um cenário.

\section{DESCRIÇÃO}

O coordenador pede para que os jogadores, inspirados pelo termo Onde, de Viola Spolin, faça uma lista de locais e ambientes possíveis de serem sonorizados. Podem ser lugares imaginários ou reais, como floresta, metrópole, fazenda, sala de aula, cozinha, praia, fundo do mar, parque de diversões, dentro de uma caixa de fósforos, espaço sideral, etc. Esta lista deverá ser elaborada coletivamente.

Na sequência, os jogadores são divididos em grupos de até dez pessoas. Cada um deverá escolher um dos ambiente listados e, na sequência, enumerar todas as fontes sonoras que podem existir neste local. Importante perceber que este mesmo espaço pode ter diversos momentos sonoros distintos, por exemplo uma praia com chuva ou de noite.

Dando continuidade, um grupo de cada vez, sem mencionar o local escolhido, deve tentar reproduzir estas sonoridades para os demais, utilizando somente os sons do corpo. Após cada apresentação, os observadores-escutadores devem tentar adivinhar o ambiente escolhido para então, um pequeno debate ser aberto para possíveis reflexões. 


\section{Jogo da História Sonorizada}

\section{DESCRIÇÃO}

Os jogadores são divididos em grupos de até dez pessoas. Cada grupo deverá criar uma história que tenha começo, meio e fim, para ser apresentada aos demais, apenas utilizando sons produzidos pelo corpo.

Pode ser usado o recurso da sonoplastia (sons naturais e ações físicas, como o ranger de uma porta se abrindo por exemplo) ou trilha sonora (músicas compostas que auxiliem na construção dos climas e ambientações cênicas). Caso os personagens da história estabeleçam um diálogo, não se deve utilizar palavras compreensíveis, podendo-se valer do uso de blablação (também conhecida por fonemol ou gramelô, é o uso de uma linguagem oral fictícia).

Durante a apresentação de cada grupo, os espectadores deverão estar sentados e de olhos fechados. A história é repetida por duas vezes e, então, o grupo que se apresentou permanece em silêncio enquanto a plateia diz o que entendeu da história. Ao final, o grupo que apresentou expõe a sua versão e, comparando com o que foi entendido pela plateia, é feita uma conversa reflexiva sobre o jogo. 


\section{CONCLUSÃO}

Ingressei no grupo Barbatuques no mesmo ano em que finalizei minha graduação: 2001. Naquela época, ainda como estudante de artes cênicas, não poderia imaginar os inúmeros caminhos que a música e o teatro iriam me proporcionar. Com toda esta bagagem, chego hoje à finalização deste mestrado. Entretanto, termino minha dissertação com uma sensação de incompletude.

Quando entrei na pós-graduação, após estar afastado por quinze anos da vida acadêmica, lembro de ter ouvido de diversas pessoas que a duração do mestrado é muito rápida. Hoje, concordo plenamente com esta afirmação. Um pouco antes de acabar a redação da presente dissertação, deparei-me com meu projeto inicial e chego agora à conclusão de que, por mais que eu tenha me dedicado à escrita, ao estudo e à pesquisa, ainda existem diversas lacunas a serem preenchidas, através de pesquisa e reflexão, para que este trabalho esteja completo, da maneira que imaginei inicialmente.

Acredito que esta pesquisa poderá vir a auxiliar muitas pessoas, sejam artistas teatrais ou de outras áreas. Por mais que este trabalho tenha sido escrito e pensado para os artistas teatrais, percebo que ele pode se aproximar e dialogar com diversos outros campos de estudo. Fico muito grato por poder compartilhar este texto com todos aqueles que, porventura, possam vir a se beneficiar destas ideias - a arte é universal, serve a todos, assim como o teatro não é feito apenas para os atores ou a música para os músicos.

Destaco aqui uma observação que considero fundamental para $o$ futuro aprofundamento deste trabalho. Durante toda a escrita, defendi com energia a importância do ensino musical do artista teatral. Entretanto, confesso que, a certa altura, uma indagação me fez parar para refletir. O questionamento foi: como se dá de fato, na prática cotidiana do ator, o resgate e a utilização do conhecimento musical? Por que vias o artista teatral acessa esse conhecimento, e como este ressurge em seu corpo, transformado em material dramatúrgico expressivo? Em que planos e em que medida o conhecimento musical contribui para o aperfeiçoamento da qualidade da performance cênica? Me assustei quando percebi que não sabia responder a estas questões.

Para responder a estas dúvidas, a presente pesquisa precisa ser continuada e aprofundada em relação ao registro da prática do ator, desse ator que usa a linguagem da percussão corporal em cena, observando e percebendo os caminhos a que ela pode levar. 
Que este mestrado sirva para os artistas teatrais que sintam esta vontade de aprofundar seus estudos musicais, estando cientes de que é um belo e gratificante caminho, muito mais cheio de perguntas do que de respostas. Mas que umas das dicas para percorrê-lo reside justamente no ouvir o outro, sentir o outro e manter o outro. 


\section{REFERÊNCIAS BIBLIOGRÁFICAS:}

AMALFI, Maestro Marcelo. A macro-harmonia da música no teatro: um novo olhar sobre a relação criativa do compositor Jean-Jacques Lemêtre com a encenadora Ariane Mnouchkine no Théâtre Du Soleil. São Paulo: Giostri, 2015.

AMORIM, Roberto R.S. Batucadeiros: Educação musical por meio da pecussão corporal. Dissertação de mestrado, Brasília: UNB, 2016.

BACHMANN, Marie-Laure. La rítmica Jaques- Dalcroze : una educación por la música y para la música. Madrid: Ediciones Pirámide, 1998.

BARBOSA, Fernando; HOSOI, André. Apostila Barbatuques: Curso de Formação Básica. São Paulo: Mimeo, 2012.

BOAL, Augusto. Jogos para atores e não-atores. Rio de Janeiro: Civilização Brasileira, 1998.

BRITO, Teca Alencar de. Koellreutter educador: o humano como objetivo da educação musical. São Paulo: Peirópolis, 2001.

, Teca Alencar de. Música na educação infantil. São Paulo: Peirópolis, 2003.

CINTRA, Fábio Cardozo de Mello. A musicalidade como arcabouço da cena: caminhos para uma educação musical do teatro. São Paulo: ECA-USP, 2006. Tese de Doutorado.

CONSORTE, Pedro Leme. Por relações mais porosas: repensando formas de trabalhar com a percussão corporal, a partir da teoria corpomídia. São Paulo: PUC, 2014. Trabalho de conclusão de curso.

DELALANDE, François. La musica es un juego de niños. Buenos Aires: Ricordi Americana, 2001. 
, François. Le son des musiques. Paris: INA- Buchet-Castel, Pierre Zech, 2001.

DI LUCA, Thiago. O desenvolvimento de competências musicais a partir de práticas corporais e criativas no fazer musical em grupo. Novo Hamburgo: Feevale, 2011. Trabalho de conclusão de curso.

FEDER, Vinícius Burlamaque. Uma etnografia do grupo Barbatuques. Trabalho de conclusão de Curso de Bacharelado - Faculdade de Ciências Sociais, PUC: São Paulo, 2011.

FONTERRADA, Marisa Trench de Oliveira. De tramas e fios: um ensaio sobre música e educação. São Paulo: Editora Unesp, 2008.

FORTE, Roberta. A música corporal na educação musical brasileira: contribuições e facilitações na visão dos educadores musicais contemporâneos. Dissertação de mestrado, São Paulo: Instituto de Artes da UNESP, 2018.

FRAZEE, Jane; KREUTER, Kent. Discovering ORFF: a curriculum for music teachers. New York: Schott Music Corporation, 1987.

GUINSBURG, Jaco. Stanislavski, Meierhold \& Cia. São Paulo: Perspectiva, 2010.

GRAMANI, José Eduardo. Rítmica. São Paulo: Perspectiva, 2010.

GRANJA, Carlos Eduardo de Souza Campos. Musicalizando a escola: música, conhecimento e educação. São Paulo: Escrituras Editora, 2006.

GROTOWSKY, Jerzy. Em busca de um teatro pobre. Rio de Janeiro, Civilização Brasileira, 1971.

HUIZINGA, Johan. Homo ludens. São Paulo: Perspectiva, 2014. 
JACQUES DALCROZE, Emile. Eurhythmics art and education. Salem: Ayer Co., 1930.

, Emile. Le rythme, la musique et l'education. Ed. Rouart \& Lerolle,

Paris: 1920.

JORDÃO, Gisele; ALLUCI, Renata; MOLINA, Sérgio; TEHARATA, Adriana. A música na escola. São Paulo: Allucci \& Associados Comunicações, 2012.

KOUDELA, Ingrid Dormien. Jogos teatrais. São Paulo, Perspectiva, 2009.

_, Ingrid Dormien. Brecht: Um Jogo De Aprendizagem. São Paulo: EDUSP/Perspectiva, 2010.

, Ingrid Dormien. Texto E Jogo: uma didática brechtiana. São Paulo:

FAPESP/Perspectiva, 2010.

KUSNET, Eugênio. Ator e Método. São Paulo: Hucitec, 1992.

LABAN, Rudolf. Domínio do Movimento. São Paulo, Summus, 1978.

MAZIERO, Mariana Gomes. Percussão corporal na Educação Infantil. Programa de PósGraduação Lato Sensu, para obtenção do título de Especialista em Educação Musical. São Paulo: FIC, 2016.

MEYERHOLD, Vsévolod Emilievitch. Teoria teatral. Madrid: Fundamentos, 1971.

MURRAY, Simon. Jacques Lecoq: Routledge performance practitioners. New York: Routledge, 2003.

NACHMANOVITH, Stephen. Ser criativo: o poder da improvisação na vida e na arte. São Paulo: Summus, 1993. 
NOVELly, Maria C. Jogos Teatrais. Exercícios para grupos e sala de aula. Campinas: Papirus, 1994.

PAVIS, Patrice. Dicionário de teatro. São Paulo: Perspectiva, 2008.

PIAGET, Jean. A epistemologia genética. São Paulo: Abril Cultural, 1978. (Os Pensadores). , Jean. A formação do símbolo na criança. R. de Janeiro, Brasília: Zahar/INL, 1975.

RAMALDES, Karine. Os jogos teatrais de Viola Spolin (Uma pedagogia da experiência). Goiânia: Kelps, 2017.

RÜGER, Alexandre Cintra Leite. Percussão corporal como proposta de sensibilização musical para atores e estudantes de teatro. UNESP. São Paulo, 2007. Dissertação de mestrado.

SCHAFER, Murray. A afinação do mundo. São Paulo: Editora Unesp, 2001. , Murray. O ouvido pensante. São Paulo: Editora Unesp, 1991.

SCHROEDER, Silvia Cordeiro Nassif. Reflexões sobre o conceito de musicalidade: em busca de novas perspectivas teóricas para a educação musical. Campinas: 2005. Tese de doutorado.

SIMÃO, João Paulo. Música corporal e o corpo do som: um estudo dos processos de ensino da percussão corporal do Barbatuques. Dissertação de Mestrado - Unicamp, Programa de pós-graduação em Educação. Campinas, 2013.

SLADE, Peter. O Jogo Dramático Infantil. São Paulo: Summus, 1977.

SOUZA, Luís Otávio Gonçalves de. A música e os efeitos sonoros na cena teatral: reflexões sobre uma estética. S. Paulo: ECA-USP, 2000. Tese de doutorado. 
SPOLIN, Viola. Improvisação para o Teatro. São Paulo: Perspectiva, 1963.

, Viola. Jogos Teatrais: o fichário de Viola Spolin. São Paulo: Perspectiva, 2001.

, Viola. Jogos teatrais na sala de aula. São Paulo: Perspectiva, 2008.

, Viola. O jogo teatral no livro do diretor. São Paulo, Perspectiva, 2010.

STANISLAVSKI, Constantin. A Construção da Personagem. Rio de Janeiro: Civilização Brasileira, 1970.

TRAGTENBERG, Livio. Música em Cena: dramaturgia sonora. São Paulo: Perspectiva, 1999.

WILLEMS, Edgar. As bases psicológicas da educação musical. Bienne: Pro-Musica, 1970.

WISNIK, José Miguel. O som e o sentido: uma outra história das músicas. São Paulo: Cia.

Das Letras, 1989. 
ANEXOS 


\section{ENTREVISTA COM STENIO MENDES}

\section{O que é um palco para você?}

No senso comum o palco é um local estratégico onde se apresenta eventos de importância para coletividades que mereçam ser assistidos por muitas pessoas com o máximo de eficiência possível. Vejo um lugar propício para revelar, contagiar estados verticais da alma humana, priorizando atividades artísticas, ou atividades que promovam a dignidade humana. Como lugar também da empatia, o artista pode ter a experiência extraordinária de sentir-se em comunhão com platéia, em estados psicológicos que consagram este local chamado palco. Mas vejo também como um lugar ancestral, ritualístico, quando as pessoas se colocam em círculo para que todos se enxerguem, se identifiquem como seres humanos e comunguem no instante presente. Agora vejo também nos laboratórios desenvolvidos junto a professora Carminda Mendes André, a importância deste lugar, quando instaurado "o estar em ritual" como com os estudantes de teatro da UNESP, o palco era convencionado por uma fita amarela em formato de círculo, era o lugar da provação, lugar crítico, da experiência mais aguda e psicologicamente mais iluminada. Na construção e exposição de máscaras, o palco se torna fundamental, além de estar propício para o discernimento, é o lugar dos "insights" onde testemunhamos o "momento gênesis" do ator se transformando, recriando, esculpindo a si mesmo para a experiência da comunhão com o coletivo.

\section{Poderia citar alguma experiência de palco que tenha te surpreendido?}

Lá pelos anos 60, quando fazia parte de uma banda de rock, fomos convidados a tocar numa festa de formatura de alunos surdos e mudos. Assim que começamos, a primeira surpresa foi ver todos eles dançando no ritmo. Percebi alguns ficaram apreciando, sentindo o som com o corpo bem próximos às caixas acústicas, era como sua pele se transformava em tímpanos expandidos, respondendo em gestos e expressões faciais às vibrações tanto graves como agudas, discernindo até as nuances melódicas da guitarra e voz. Foi incrível ver os casais dançando e curtindo com mesma alegria dos jovens de outros bailes. Assim como as pontas dos dedos vão servir como o órgão de visão aos cegos, incrivelmente o corpo humano está sempre surpreendendo, superando limites de suas competências. É nesta visão extraordinária que me inspira a pensar que a música corporal vai surpreendendo participando da prática musical em muitas escolas do Brasil e do exterior, em grupos diversos, orquestras, teatro e 
dança. Para mim esta atividade está em estado de maturação e vejo um potencial promissor para ser utilizada em outras áreas como a atividade terapêutica motora e psicológica.

Você acha que a música corporal colabora de algum modo para a evolução de um artista, sendo ele já atuante ou em formação? Como se daria este processo?

Podemos sugerir que a evolução do artista está principalmente no mundo sensível, nas subjetividades das relações humanas e de todo o contexto que o cerca e o provoca à contemplação e à ressignificação. A atividade da "música corporal", pode ressignificar o corpo, primeiro como um tambor, batendo, estalando, esfregando, intensificando consideravelmente, a "presença" do artista. Música corporal vista como um fazer musical, sons da própria pele e os sons fonéticos também serão poetizados, destacando seus aspectos melódicos principalmente nas vogais, e percussivos na consoantes. É perceber, discernir, harmonizar com a coerência, melodias, timbres, batendo, estalando, esfregando, em toda a extensão do corpo, nas suas diferentes densidades musculares, na dança rítmica no movimentos de ósseos articulados, dialogando com as paredes ocas e graves, sobre o peito, abdômen, marcando nas pernas, pés o nosso chão, o passo, o pulso. O coração, respiração que se integram aos estalos dos dedos, dividindo em preciosos segundos em semínimas e o grito primordial, nas cordas ressoantes, pregas laríngeas, consoantes percussivas, vogais melódicas, desliza plosiva, oclusa no céu da boca a língua entre palatos, dentes e lábios, é um instrumento extraordinário. Para o artista a experiência de usar o corpo como se fosse um instrumento musical, leva a um deslocamento do sentido habitual deste corpo, para o olhar de contemplação, de distanciamento. O nosso eu-consciência se separa do objeto-corpo e pode observar o corpo orgânico como um novo instrumento musical, assim como o ator também desloca e cria uma separação psicológica de seu corpo habitual, para a entrega, a se deixar possuir por outra persona, com outros hábitos. Este estado de distanciamento e de contemplação se desdobra aqui como um estado de luz, de "presença", uma atenção limpa de qualquer dispersão, que vai qualificar o artista no seu grau de clareza de percepção-atuação.

Como você enxerga a função do jogo no aprendizado musical? Em relação as práticas existentes de ensino musical, acha que o uso do corpo para fazer os jogos traz algum diferencial?

Uma prática vivenciando a nossa natureza musical, nos sentimos mais despertos. Ao 
entoarmos um canto simples, compartilhado com outra pessoa ou grupo, de repente nos sentimos animados, batemos palmas. E as mãos, podem naturalmente percutir em todo nosso corpo. Dentro de um ritual de nossos jogos, de repente como a luz de um flash, o abrir dos olhos, somos que despertados, de um impulso brincante somos que impelidos à investir naquele, "instante alquímico" pois intuímos que é capaz de transformar uma rotina tediosa em diversão, em festa. Com uma experiência essencialmente sensória, esta música à flor da pele, nos entregamos à escuta, aos impulsos de movimentos, gestos, expressão facial, intercâmbio visual, de repente achar graça de nós mesmos, todos em jogo, criando, brincando com os sons, ruídos estranhos, até nos encontrar com Dionísios, dançando a beleza dos timbres, ritmos, harmonias, de nossa própria natureza poética. Aí pensamos, sim!!! podemos mudar a nossa cabeça, o mundo, provocar e sermos provocados através da arte, ter essa consciência e experiência, necessária e urgente. Nesta perspectiva a música corporal é fundamental.

\section{Como foi que começou a trabalhar com atores?}

Mais diretamente foi em 1995, na Escola Macunaíma, quando a professora de teatro, na época atriz e diretora, Carminda Mendes André, me convidou para trabalhar a música corporal com seus alunos, montando uma peça chamada "Kaspar", do escritor austríaco Peter Handke, foi fantástica a experiência, um trabalho todo composto pela criatividade e performances dos próprios atores. Anos mais tarde em 2014 fizemos uma parceria na Unesp, ministrando aulas, desenvolvendo um laboratório de jogos e improvisação de teatro e música corporal com alunos atores pra licenciatura e bacharelado durante 4 anos.

\section{Quais atividades e jogos que você praticava com os atores?}

No caso da improvisação com a música corporal, o mais importante é praticar numa sequência de jogos a premissa básica: "ouvir o outro, sentir o outro e manter o outro" que me foi transmitida por um professor alemão que passou pelo Brasil nos anos 80, também cantor e ator, de nome Theophil Maier. O exercício que inaugurou esta atividade também vem do mestre Theophil, consiste uma sequência de quatro fases, quatro movimentos, inicia-se com sopros, percussão suave, depois na segunda fase percussão mais forte, na sequência surge a percussão vocalizada que incluía a blablação e por fim, no quarto movimento só vogais e cantorias. Este exercício também marcava o ritual de iniciação, apagavam-se as luzes, com 
muito silêncio pra começar e terminar. Outra proposta que vale a pena destacar, talvez de assimilação mais imediata com os atores, surge no estudo da prosódia. A prosódia, blablação, grammelot, onde a musicalidade fonética vai integrar o estudo da música corporal, proporciona ao ator a trabalhar no "avesso do verso", as entranhas da fala, com a criação de línguas fictícias, sem significados. Serão então destacados o jogo entre vogais e as consoantes, outros aspectos musicais da fala, como timbre, melodia, ritmo, andamento, pausas, emoção, intenção, interpretação entre outros, quando são experienciados separadamente, explorando seus potenciais expressivos e por outro lado vai atuar também como provocação para vir à tona as singularidades poéticas dos alunos participantes.

\section{Quais os objetivos de utilizar estes jogos? O que você procura trabalhar com eles?}

No primeiro momento podemos trabalhar a coordenação motora, habilidades, criatividade, desinibição, a pesquisa, trabalhar no estranhamento, libertar-se dos estereótipos, descobrir singularidades, compartilhar suas próprias frases sonoras harmonizando com o coletivo. Num segundo momento colocar esse material em composições, cenas, performances. Num terceiro momento podemos focar no sentido de "presença". O jogo parece que foi inventado para este fim, provocar e o estado de alerta, sentir a presença e isto é explícito nos jogos de improvisação principalmente entre dois jogadores, frente a frente, onde somos assaltados por toda a sorte de inseguranças, de sentir-se desafiado, competindo, em meio a tantos ruídos internos que mal conseguimos escutar a nós mesmos. Só a experiência vai dando a oportunidade de ir relaxando até chegar à brincar com o companheiro e a expressão do jogador se ilumina e a presença com arte é também afetiva, contagia a todos os presentes.

\section{Inventou ou aprofundou algum jogo já existente?}

Alguns jogos inicialmente para músicos tomaram um rumo surpreendente entre os atores. Um exercício criado por Fernando Barba, chamado Carrossel, onde se institui 4 grupos e cada grupo vai representar um coro, e cada coro terá seu próprio regente que vai criar, improvisar um mote para ser executado pelo seu coro, de forma que se formarão quatro grupos com 4 regentes e seus coros soando ao mesmo tempo e terão de se harmonizar, cada um com frases melódicas, percussivas. Na continuidade seus regentes também vão se alternando até que todos possam propor suas próprias invenções sonoras ao seu grupo. Neste mesmo jogo, agora proposto para os estudantes de teatro, houve desdobramentos inesperados. De repente cada 
coro se deslocou do espaço pré fixado e ocupando toda a área da sala, se transformou em quatro grupos musicais dançantes, criando coreografias, interagindo cenicamente uns com os outros grupos. O que para mim foi mágico, para eles foi natural... $\mathrm{Na}$ sequência numa outra proposta, criamos quatro grupos atores. Partindo com a música corporal, eles saíram da sala de aula, cada grupo com seu coro improvisado, foram caminhando e dançando. de repente surgia uma pausa então eles se lançavam cenicamente, interagindo com espaços, objetos, ressignificando-os poeticamente criando várias cenas curtas. Observando a desenvoltura desses seres atuando e a incrível disponibilidade para brincar com o teatro testemunho o quão libertadora é a convivência de músicos e os atores trabalhando juntos, como imagino também, junto às outras áreas artísticas. Um outro jogo que nasceu deste casamento teatro e música foi o "jogo de petecas", com uma quadra demarcada com fita crepe no meio da sala, iniciava-se uma partida em que o time que perdesse iria "pagar o mico" iria ter que improvisar uma cena qualquer criada anteriormente pelos atores jogadores, escrita em um papelzinho. Então muitos papeizinhos ficavam guardados dentro de uma caixinha para serem sorteados na hora da improvisação. Ficava estabelecido também que os ganhadores iriam julgar a atuação dos perdedores. No primeiro momento era como um jogo de vida ou morte, tinham horror de ficar entre os perdedores. Os ganhadores julgavam de forma séria, coerente com status de universitários às vezes com um rigor pouco generoso. Mas no andar da carruagem eles descobriram que podiam criar personagens delirantes para julgar e analisar seus colegas. E medida que o jogo ia passando o time mais forte também começava a errar de propósito, para poder também atuar cenicamente, assim quebrando a compulsão de competir, se deram conta que o perdedor estava mais próximo do teatro. 


\section{ENTREVISTA CARLOS BAUZYS}

\section{Quais são as suas referências musicais?}

Em casa minha mãe sempre escutou muito Beatles, muito mesmo (risos), então eu cresci ouvindo muito Beatles e o meu tio também me apresentou muitas coisas legais, assim como meu irmão também. Coisas de rock progressivo, né? Yes, King Crimson, Gentle Giant. Também depois mais para adolescência, continuei escutando muito rock progressivo, depois MPB. Me viciei também em música brasileira e depois música erudita, enfim, ouvi bastante coisa assim. Tudo que é bom eu gosto, eu escuto. Adoro músicas étnicas também, adoro músicas folclóricas. Adoro, ouço de tudo, já toquei de tudo, já escutei de tudo. Nesse sentido eu sou bem eclético assim, pra mim basta ser música boa que eu vou curtir e vou adorar fazer se aparecer a oportunidade.

\section{Como foi a sua formação musical?}

A princípio fui muito autodidata, comecei a tocar instrumentos. Na escola peguei uma flauta e me viciei na flauta, ficava tocando flautinha o dia inteiro. Depois peguei o violão. Ficava tocando violão dia inteiro, aprendendo, pegando os toques com os amigos, aí monta banda, não sei o quê. Depois flauta transversal, aí percussão, outros instrumentos. Eu já sabia que eu ia queria ser músico. Quando foi para entrar na faculdade que eu fui estudar mesmo, aprender a ler para poder prestar vestibular. Fui fazer teoria, entender tudo. Aí eu passei na Unesp, fiz bacharelado em composição e regência. Para mim foi o curso certo porque era justamente o que eu queria fazer. Assim, compor e reger. E arranjar e tal. Pra mim foi um curso ótimo. No entanto, eu acho que muito da minha formação vem dos grupos que eu criei. Eu nunca me conformei só com o que eu aprendia na faculdade, eu queria aplicar o que eu aprendia na faculdade na prática. Na faculdade, as vezes, é difícil você ter prática. Eu já tinha uma banda grande, que você conhece, a Trombada, que eu liderava, que eu compunha, que eu arranjava, junto com a galera lá de Vinhedo. Depois eu criei mais um grupo vocal, o ÓcTrombada porque eu gostava muito de música à capela. Comecei a pesquisar isso e arranjar músicas à capela. E testar e cantar e fazer. Chegamos até montar um musical infantil com esse grupo ÓcTrombada. Tinha também o quarteto violões, que eu queria explorar os violões. Tinha o grupo de percussão, um monte de coisa que eu montei tudo com nome Trombada. Trombada

Auê, ÓcTrombada, TrombadaLata, que era de percussão, TrombadoLão, que era o de violão 
(risos) e foi a minha escola, minha grande escola acho que foi isso aí, foi a Trombada. E aí tudo eu aprendia na faculdade e botava na prática nos grupos. A gente experimentava muito, produzia bastante coisa. Isso foi muito importante para mim

\section{Quando você percebeu a importância profissional que que a música teria na sua vida?}

Imagina, eu era adolescente na escola. Eu não ia mal na escola porque, graças a Deus, era inteligente e esperto, assim, até certo ponto. Mas eu era muito focado só em música. Eu ficava lá no fundão, quando a aula estava chata e ficava tocando bateria na carteira. Sofri muito bullying por causa disso (risos) mas eu realmente me ligava muito em música. Graças a Deus tinha uma escola que era bacana, alguns professores se ligavam disso e me ajudaram neste sentido. Então por exemplo, muitos trabalhos de literatura, eu lembro que o professor deixou eu fazer uma música sobre o tema. Então eu fiz música sobre o romantismo, sobre o realismo (risos) e apresentava. Ao invés de fazer um trabalho escrito sobre o negócio, eu apresentava uma música na sala de aula com aquele tema. Enfim, coisas assim. E aí eu vi que não ia ter jeito, né? Não tinha o que fazer, eu era músico, já sabia que era isso e era isso que eu queria fazer. Eu ia ter que dar um jeito. Então a primeira coisa você foca é entrar na faculdade, se bem que antes de entrar na faculdade, já comecei a trabalhar com música. Já dava aula, já ganhava uns trocos com isso e quando eu entrei na faculdade que eu entendi qual era o campo, onde exatamente eu ia poder trabalhar com isso. Mas logo eu já caí nos musicais, que foi minha grande veia profissional. E aí comecei a trabalhar com isso e não parei mais.

\section{Teve alguma mudança na sua trajetória musical após conhecer a pesquisa de percussão corporal do grupo Barbatuques?}

Após eu conhecer a pesquisa de percussão corporal do grupo Barbatuques? Quem me apresentou primeiramente foi um cara bacaninha aí que chama Maurício Maas (risos). Éramos adolescentes ainda. Eu tinha uns 17 anos, 18, por aí e pirei porque, como disse, também sempre gostei muito de música a capella. Aí eu enxerguei nisso uma grande expansão também do jeito de fazer música capela. Então no próprio ÓcTrombada eu já comecei a pesquisar bastante percussão corporal, misturar com os arranjos vocais que eu fazia. Eu pirei na percussão corporal, então fui fazer o curso com Macalé, Flavinha e Dani Zulu. O Barba apareceu algumas vezes, o Stênio também, lá na Oswald de Andrade, onde realmente expandiu meus conhecimentos de percussão corporal e comecei realmente a cair de cabeça 
nisso. Aí pirei, ficava o dia inteiro pesquisando, tocando percussão corporal. Até para poder tirar com propriedade as músicas, resolvi escrever algumas músicas do Barbatuques. Comecei com Barbapapa's. Escrevi na grade e apresentei um dia para o Barba que pirou e falou: "Pô! Maluco! (risos) Chega aí participar do grupo de estudos que a gente tem". Comecei a participar do grupo de estudos e daí foi de cabeça né? Escrevi outras músicas dos Barbatuques, ficava pesquisando também junto no ÓcTrombada. Em muitos musicais que eu fiz também acabei usando. Tinha esse recurso, enxerguei dentro das cenas várias possibilidades de poder usar isso e sempre deu muito certo. As pessoas sempre gostavam muito. Até que o Barba me convidou para montar junto com ele a Orquestra Corporal, que foi mais um grande centro de pesquisa também e depois, enfim, para dirigir musicalmente junto com ele o novo disco do Barbatuques, o Ayú. Foi para mim uma das coisas mais legais que aconteceram na minha vida profissional que eu tenho muito, muito, muito carinho porque eu sempre fui fã, muito fã do grupo Barbatuques e aí ter esta oportunidade de trabalhar com eles e montar este cd foi realmente algo que vai ficar pra minha vida.

\section{Como aconteceu a sua aproximação com o teatro?}

Minha aproximação com o teatro foi também desde a adolescência lá em Vinhedo. Já participava de grupos de teatro como ator, assim, atuando. Eu adorava, adorava! Mas quando eu me vi forçado a realmente estudar muita música para poder passar na faculdade, acabei parando. Fiquei mais focado na música. Mas sempre estive muito próximo ao teatro, sempre gostei muito do teatro. Então, já na faculdade, foi natural eu ter caído nos musicais. Eu participava de um coral com o maestro Abel Rocha. Ele gostava muito de mim, eu regia algumas coisas no coral e tal. Aí ele me chamou para ser assistente dele no musical Hair na EAD. Foi o meu primeiro musical que eu tocava e regia a banda. A partir dali que eu me apaixonei completamente e nunca mais parei musical. Já fui emendando um no outro. Trabalhei muito tempo na EAD montando musicais lá. Então minha aproximação com teatro foi sempre muito grande. Teatro e música sempre andaram muito juntos para mim.

\section{Como você enxerga o atual panorama da educação musical dos artistas da cena?}

Uma coisa curiosa é que realmente eu enxergo muito a proximidade entre teatro e música. Eu vejo que os atores, mesmo esses que não estão especificamente em musicais, são sempre muito abertos à música. Eu sinto que se no Brasil já houvesse uma educação musical desde a 
escola, primário mesmo assim, até.. que a educação musical acompanhasse mesmo a educação escolar, eu sinto que seríamos imbatíveis nesse quesito de musicalidade desenvolvida. Já temos muita música boa na nossa cultura e eu percebo essa abertura dentre os atores. Eles sempre muito disponíveis para a música. Mas se houvesse uma formação maior, melhor, tanto nas escolas quanto nos cursos de teatro e nas universidades de teatro, acho que isso iria ser muito mais explorado, expandido. Mas é uma coisa muito linda de ver os atores, como eles estão sempre disponíveis, abertos à música e à musicalidade

\section{Como você vê a abordagem desta questão nas escolas de artes da cena que você conheceu?}

Eu já trabalhei na escola de artes Operária, muitos anos trabalhei na EAD, já trabalhei também no Célia Helena, enfim. Eu percebi sempre essa disponibilidade muito grande dos atores, dos artistas com a música, uma abertura uma vontade, uma disponibilidade. Tanto que na EAD, tantas vezes fizemos musicais lá. Ou peças de teatro com muita música. Só na EAD eu fiz o Hair, como já disse. Depois Ópera do Malandro, com o Iacov Hillel, que foi uma linda montagem. Depois fiz Prepare o seu Coração, que foi um musical bem legal, também interessante, com arranjos originais sobre a era dos festivais. Depois eu fiz Fuente Ovejuna, com a Isabel Setti, que era uma peça de teatro mas com muita música. Antes disso fiz também, com o Macalé ${ }^{56}$ em parceria, Desde que o samba é samba, que era uma proposta muito interessante. Tudo era sonorizado, tudo era sensorial e a gente usava muita pesquisa sonora, tanto com percussão corporal quanto com voz e improvisos dos atores. Musicalmente era bem interessante, uma proposta mais experimental. O último que eu fiz foi o Pífaro, um musical inteiramente original. Eu fiz as músicas, o texto era do Paulo Faria e a direção do Yacov Hillel, que era uma adaptação do Flautista de Hammilin pro Brasil, muito interessante, este também adorei fazer! E todos os musicais que a gente fez lá na EAD foram muito bemsucedidos justamente por causa disso, os atores sempre muito abertos, disponíveis e com uma musicalidade aflorada. Então sempre foi muito gostoso de trabalhar. Fácil e gostoso de trabalhar na EAD, sempre muito gratificante.

\footnotetext{
${ }^{56}$ Meu apelido.
} 


\section{Qual a importância do aprendizado musical para os atores?}

Como sou justamente um músico muito ligado ao teatro, eu vejo a importância para os dois lados. Eu vejo a importância do aprendizado musical para os atores porque tudo, tudo é ritmo. Tudo é melodia, tudo é música e a musicalidade te desenvolve. Envolve coisas na nossa mente e fazem você poder ir muito mais longe. Eu vejo isso nos atores como eu também vejo nos músicos, nos cantores principalmente. Mas nos músicos também, esses que tem uma abertura cênica, uma abertura para o teatro, como eles interpretam tudo melhor, naturalmente. Como fica tudo mais verdadeiro, mais profundo, mais bonito. Então eu enxergo muito esta importância e como essas duas artes realmente andam juntas ou deveriam andar juntas, sempre.

\section{Acha que estes estudantes chegam preparados musicalmente no mercado de trabalho?}

Eu acho que poderiam chegar melhor preparados. Claro que o talento ajuda porque aí você tem mais facilidade de pegar tudo. Eu não enxerga o talento como normalmente as pessoas enxergam. Eu acho que música é uma capacidade humana. Ponto. Assim como fazer conta, como falar, andar, enfim, é uma capacidade humana e deve ser desenvolvida para um ser humano melhor. Assim como um dia, a maioria dos seres humanos não sabia fazer contas, hoje a maioria sabe fazer contas e isto deixou uma civilização melhor, mais avançada. Também acho que deveria ser assim com a música. É uma habilidade humana, uma capacidade humana que deve ser desenvolvida por todos para uma civilização melhor. Mas claro que tem aqueles que vem com mais facilidade, que é o que a gente chama de talento. Para mim essa facilidade vem de outros lugares, vem de vidas passadas. Você já teve um treinamento prévio numa vida passada você vai chegar nesta com mais facilidade, mas essa é uma visão minha, enfim. Voltando a sua pergunta, eu acho que se houvesse justamente esse trabalho de base nas escolas e nos cursos superiores, eles chegariam bem melhor preparados. É o que eu tentei fazer como coordenador do curso do SESI de teatro musical, alfabetizar. Se alfabetizar musicalmente porque não é nenhum bicho de sete cabeças e ajuda muito, muito, muito. Você ter noção de teoria musical, você saber ler, você ter esse trabalho de coral, né? Porque sempre você vai fazer teatro ou teatro musical, o trabalho do Ensemble, do coro é muito importante e é toda uma prática você sabe cantar as vozes, você saber se encaixar dentro da harmonia, é toda uma prática que requer treino. Então eu percebo hoje vendo os alunos que se formaram já no Sesi, com essa formação musical mais sólida, a diferença que 
isso faz na vida deles. Eles conseguem pegar a partitura que dão no ensaio, levar para casa e estudar, coisa que se eles não tivessem formação não conseguiriam porque ficaria dependendo sempre de alguém para ensinar. Não, eles consegue pegar, levar pra casa e estudar, trazer pronto no dia seguinte. Eles têm uma compreensão maior da música que está acontecendo, eles pegam tudo com mais facilidade. Então esse processo de alfabetização, que no caso do Sesi dura 2 anos, tempo suficiente para ter uma boa base, eu acho muito importante e eu adoraria que houvesse isso tanto nas escolas quanto nos cursos superiores, faria uma grande diferença.

\section{De que modo a pesquisa do grupo Barbatuques começou a aparecer nos seus trabalhos de preparação e direção musical?}

Uma coisa que eu enxerguei na percussão corporal foi justamente a possibilidade de usá-la como ferramenta para musicalização e é uma ferramenta valiosíssima, por que? Porque é o nosso próprio corpo, né? E a gente pode fazer tudo com nosso corpo. Ritmos, melodias e sentir no próprio corpo. Então no curso do SESI eu também usei a percussão corporal como instrumento de musicalização que foi de grande ajuda pro ator entender a musicalidade no seu próprio corpo, aplicar as coisas que aprende na teoria musical como prática musical no próprio corpo e isso foi muito valioso também. Sempre que estou fazendo um arranjo ou direção musical e muitas vezes aconteceu de eu perceber na cena essa possibilidade de usar percussão corporal porque fazia sentido aquilo ser feito com percussão corporal dentro da cena. E isso então também foi um instrumento muito valioso para diversificar. Musicalmente é legal você saber diversificar nos arranjos, então mesmo eu tenho uma orquestra, legal, muitas vezes vou usar a orquestra. Mas também adoro usar coisas a capella, eu adoro usar percussão corporal, eu adoro usar instrumentos de sucata, enfim, eu acho muito legal diversificar e quando você enxerga na cena possibilidades de usar esse recursos, eu acho que não pode perder a oportunidade (risos) porque realmente fica muito legal, tudo fica unido.

Como foi participar da criação e concepção do curso de Teatro Musical do Sesi SP em 2014?

A criação do curso se deu da seguinte forma: eu fui chamado pelo Atelier de Cultura, que é a empresa que ofereceu isso ao Sesi. Eles montaram uma equipe que tinha um coordenador de música, que era eu, um coordenador cênico que era a Chris Trevisan, junto com Saulo 
Vasconcelos, tinha a coordenadora de dança, Vivian Albuquerque e a coordenadora especificamente de canto que era Sara Sarres. A Chris era também a coordenadora geral. Juntos fizemos uma longa pesquisa, entrevistamos mais de 50 profissionais do meio, fomos visitar escolas no exterior e a partir disso começamos a desenvolver a grade que seria do curso, o que a gente achava que esse curso deveria ter, quantos anos e tal. No final ficou um curso de 3 anos onde o último ano é mais de montagens. Escrevemos todas as ementas de cada disciplina, o que daria em cada bimestre de cada disciplina. Foi um trabalho de um ano a gente levantar esse curso, apresentar para ser aprovado pelo MEC. Aí a gente abriu o curso e realmente ficou muito bom. Temos pianistas para acompanhar todas as aulas, é um curso muito completo tanto musicalmente, corporalmente, cenicamente. Ficou um curso bem completo para ator de teatro musical.

\section{Por que criou uma disciplina chamada "percussão corporal" neste curso de teatro musical?}

Eu enxergo muito a percussão corporal como instrumento forte de musicalização para o ator também conhecer mais do seu próprio corpo. Desenvolver essa noção rítmica e como instrumento para eu poder aplicar a teoria musical na prática, no próprio corpo. Para os atores entenderem por exemplo, as subdivisões musicais que eles estão aprendendo na aula de teoria. Colcheia, semicolcheia, semínima e aplicar no corpo. Fora isso, a percussão corporal, que na prática que a gente sempre fez no Barbatuques e no grupo de estudos, sempre trouxe muito lado da improvisação, da improvisação musical. Com os elementos que você tem musicalmente utilizando o próprio corpo, improvisar em grupo sempre foi uma prática muito valiosa para as pessoas irem soltando a própria musicalidade. Começarem a entender que eles são artistas criadores de música inclusive, e quando você está criando em conjunto, você desenvolve essa percepção de que você precisa estar sempre conectado, sempre ouvindo tudo que está seu redor para você poder criar algo coerente com tudo aquilo e isso vai te dando, vai criando ferramentas incríveis para o ator. Vai realmente desenvolvendo um outro lado da mente que eu enxergo de primordial importância, tanto no quesito de improvisação, de criação quanto de percepção. Então, por todos esses motivos que a percussão corporal faz parte do curso teatro musical e agora com uma turma já formada, eu percebo que foi um acerto, realmente faz muita diferença, é uma ferramenta valiosíssima. 


\section{Poderia citar alguns dos jogos musicais que você utiliza nas preparações musicais?}

Os jogos musicais que a gente usa na percussão corporal, a gente usou muito por exemplo no espetáculo que eu citei "Desde que o Samba é Samba". A gente também usa no curso do Sesi, como improvisos. Um deles é a sequência minimal, onde um por vez, numa roda, no sentido horário ou anti-horário, vai criando uma célula musical, que tenha coerência com que veio antes, que converse, dialogue. Pode ser rítmica, melódica e aí o outro cria algo em cima e aí o outro, e o outro e assim por diante até que a roda fique completa, já com cada um fazendo sua célula musical. A partir daí, vem um regente para o centro e começa a brincar com essas células. Seleciona algumas e corta as outras, aí você ouve só algumas células separadamente. O regente pode fazer combinações diversas, brincando com elas, fazendo elas dialogar. Aí pode escolher uma só para todos os outros aprenderem de um lado da roda, mais uma para todos aprenderem do outro e fazer brincadeiras com elas. Enfim, tem diversas maneiras de diversificar essa regência e é um super exercícios muito legal, muito interessante. Tem outros jogos de diálogos musicais, como se fossem duelos. Tem jogos de flecha onde começa com uma flecha simples com uma palma, passando de um para o outro e depois essa palma pode começar a ter um ritmo definido, uma célula rítmica e depois pode ter uma melodia. São diversos jogos musicais que ajudam a desenvolver a musicalidade.

Inspirado nos jogos utilizados pelo Barbatuques, você inventou ou aprofundou algum jogo?

$\mathrm{Eu}$ acho que nessas pesquisas que a gente fez no "Desde que o samba é samba", acabamos aprofundando muitos jogos porque eles realmente tinham a necessidade virar uma música, uma sonoridade para a cena. Então acabamos desenvolvendo maneiras de trazer os jogos de improviso para cena, para virarem algo mais concreto ali, né? Outra coisa que eu acabei desenvolvendo bastante com o ÓcTrombada, que era um grupo mais vocal, foi o exercício da flecha, como eu disse, mas utilizando como exercício melodias e harmonia, o que deu para brincar bastante, criar bastante coisa com isso.

Acompanhando e colaborando com o trabalho do Barbatuques por tantos anos, o que você percebe de evolução no grupo?

Uma coisa muito interessante que aconteceu e que eu notei no grupo Barbatuques, que é um grupo que já tem mais de 20 anos e eu acompanhei grande parte desses 20 anos de maneira 
cada vez mais próxima, é que no início tudo partia mais do idealizador e fundador do grupo, o Barba. Ele que trazia as músicas e os arranjos. Ele fazia tudo e tudo era muito em cima dele. Mas ele, na sua sabedoria também de mestre, foi incentivando os outros integrantes do grupo a criar. Justamente também a partir desses jogos de percussão corporal e de improviso que as pessoas foram desenvolvendo a própria criatividade. Foram se soltando na própria musicalidade e ao longo do tempo, isso foi surtindo resultados muito interessantes. Já no Ayú, que foi o último disco do qual eu fiz a direção musical junto com Fernando Barba, já notei como apareceram outros integrantes compositores que colaboraram com o grupo, fazendo músicas lindas, incríveis com arranjos diferentes, mais elementos musicais, mais inovadores, coisas muito interessantes. Isso foi há três anos atrás. Aí hoje, por coincidência, eu fui em um ensaio do grupo, porque me chamaram para fazer direção musical do novo infantil e para minha surpresa eu chego lá hoje e eles já me mostram a gravação de 9 músicas, uma de cada integrante, uma música mais linda que a outra, mais incrível que a outra, cada uma completamente diferente da outra, com a cara da pessoa, com elementos diversos. Aí que me dei conta de como esse trabalho é fundamental, é lindo, de transformar as pessoas. Porque o que faz a percussão corporal e esse jogos de improviso é justamente isso, você transforma um músico de um artista meramente reprodutor para um artista criador. E foi o que aconteceu com o Barbatuques, a prova viva disso é o Barbatuques, graças também a todo esse trabalho que o Barba fez com o grupo ao longo dos anos. Isso foi muito lindo de ver e ficou muito claro hoje, como todos os integrantes do Barbatuques não são apenas artistas reprodutores. $\mathrm{E}$ que já eram fabulosos porque fazer o que o Barbatuques faz não é para qualquer um, já é super difícil fazer o que eles fazem mas eles já não são mais só artistas de execução, eles são todos agora músicos criadores e também compositores criadores. Muito legal isso! Bravo!!

\section{Alguma mensagem sobre a educação musical para os estudantes de artes da cena que desejem ingressar nesta carreira?}

Olha, eu acho que o meu principal conselho sobre educação musical para os estudantes de artes da cena ingressar nessa carreira, tanto de teatro quanto de musical, seria esse: não perder a oportunidade de se alfabetizar musicalmente. Existem diversas maneiras que pode fazer isso. Tem cursos na própria OMB (Ordem dos Músicos do Brasil), tem cursos onde você pode ou ter um professor particular ou entrar em alguma escola que tenha essa formação. Para isso 
a melhor forma é usar como recurso a percussão corporal como instrumento, instrumento de musicalização. Você é o artista de teatro, é um artista que usa o próprio corpo como instrumento de trabalho, a própria voz. Então enxergar a percussão corporal como a expansão desse trabalho do seu próprio corpo é muito importante pro ator. Te dá milhões de outros recursos, tanto corporalmente quanto musicalmente. Fora tudo que a percussão corporal traz, como a gente já citou, dos jogos de improvisos, onde você vai desenvolver sua criatividade musical, a sua musicalidade, a sua percepção em conjunto. Então é isso assim. Eu percebo hoje que é de grande valia para qualquer ator, ser alfabetizado musicalmente e ter esse conhecimento do corpo como instrumento musical. Usar o corpo como instrumento de musicalização de si próprio. 
Sinais regência (concepção e desenho: Stênio Mendes)

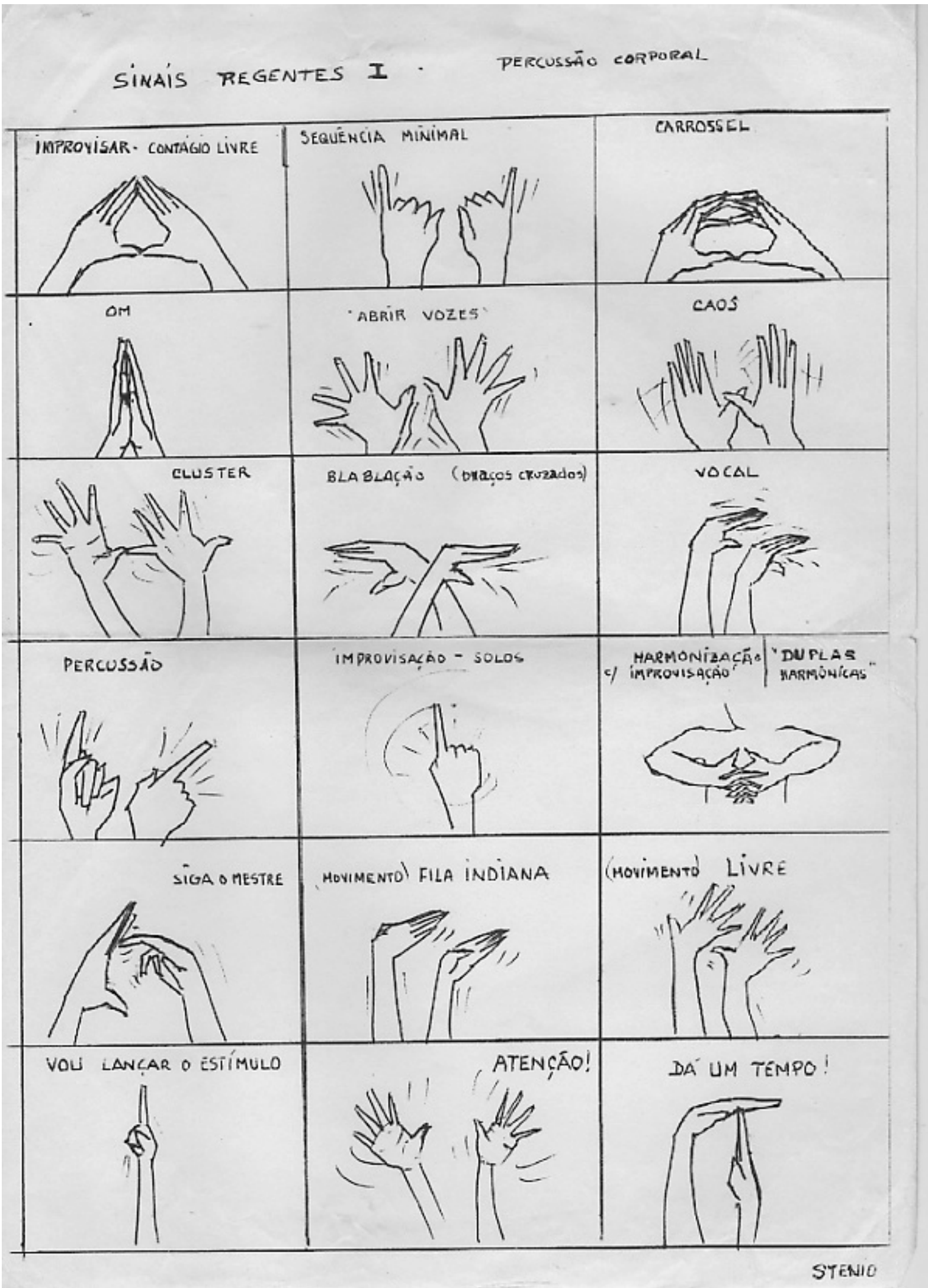


127

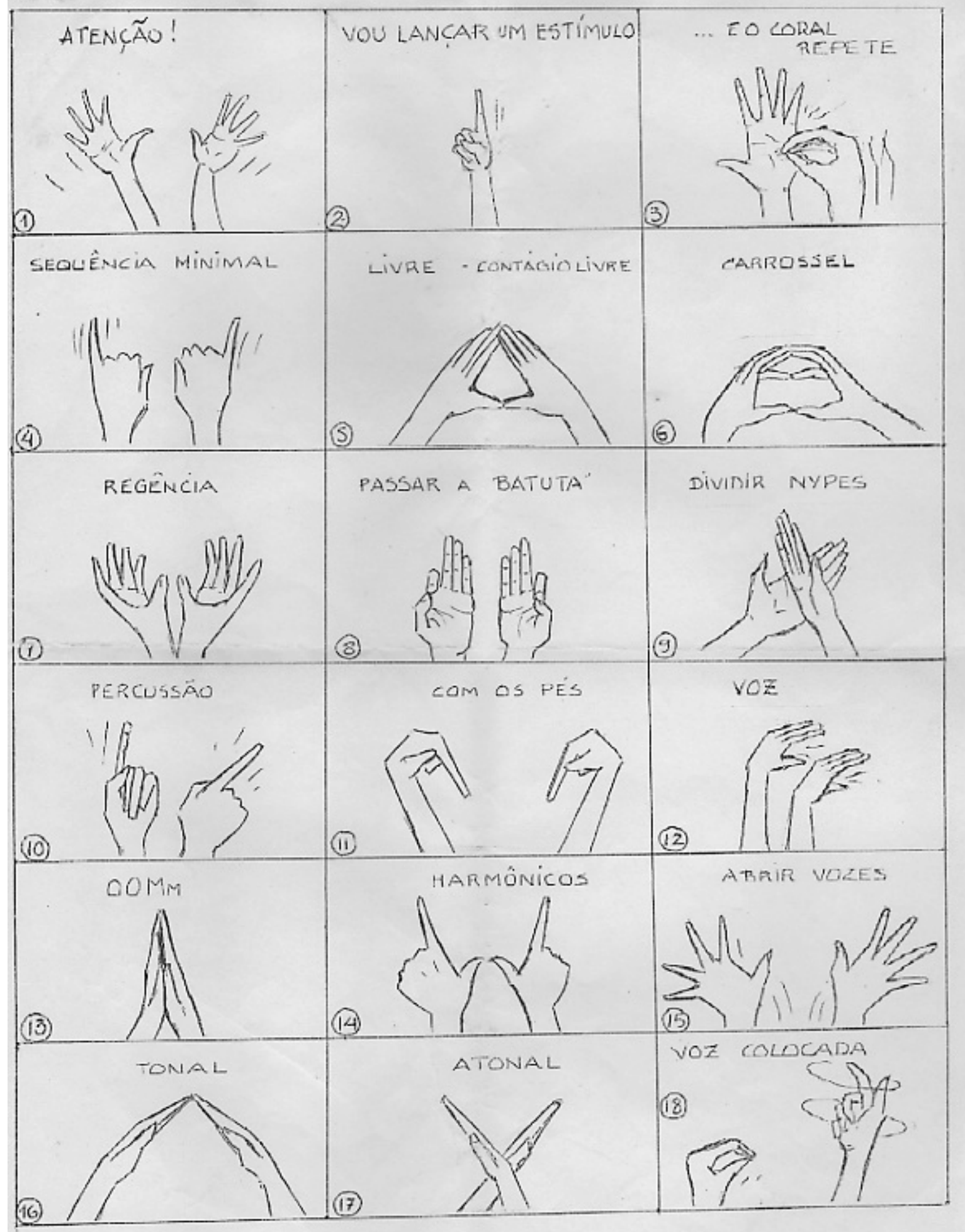




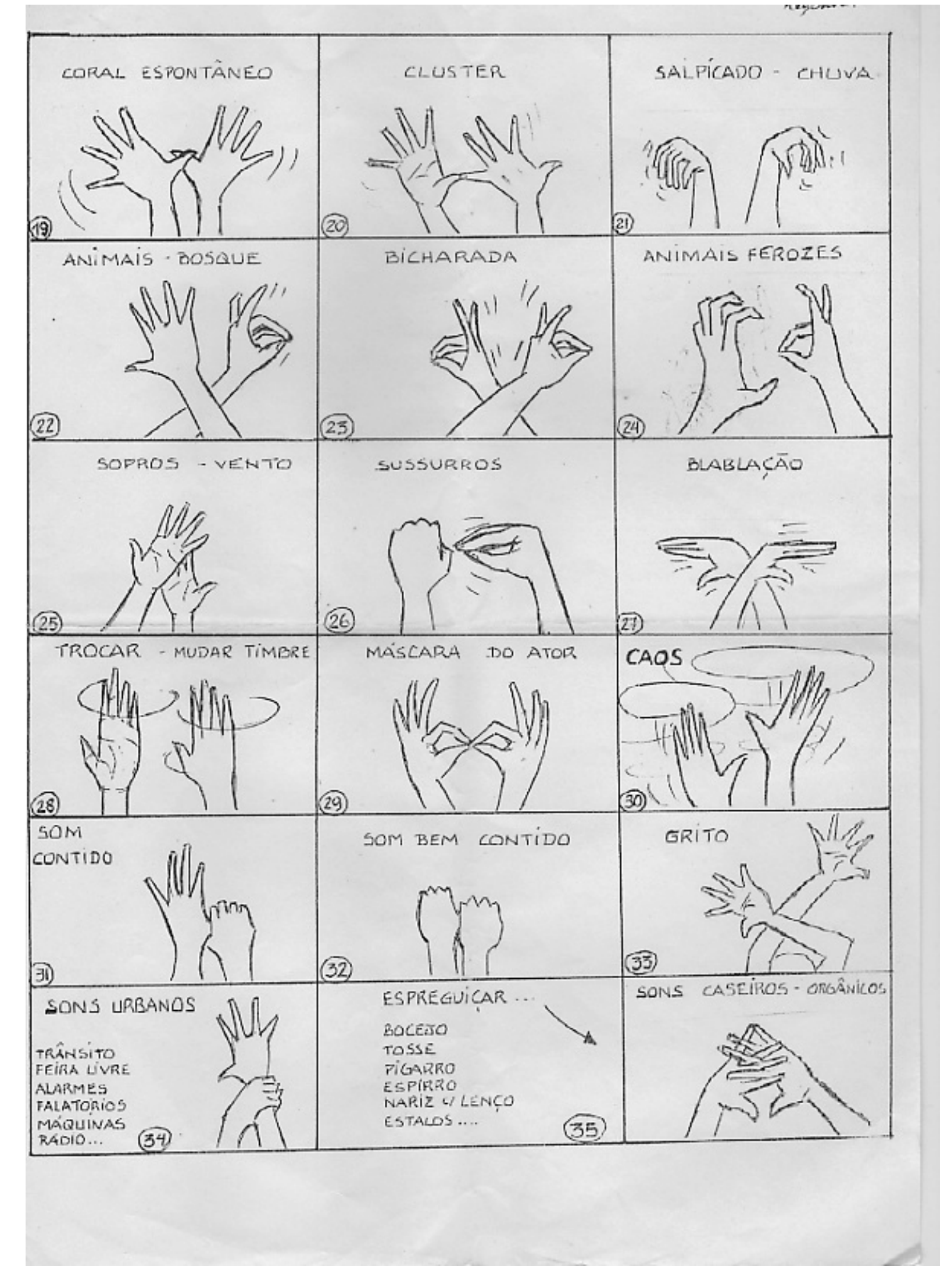


129

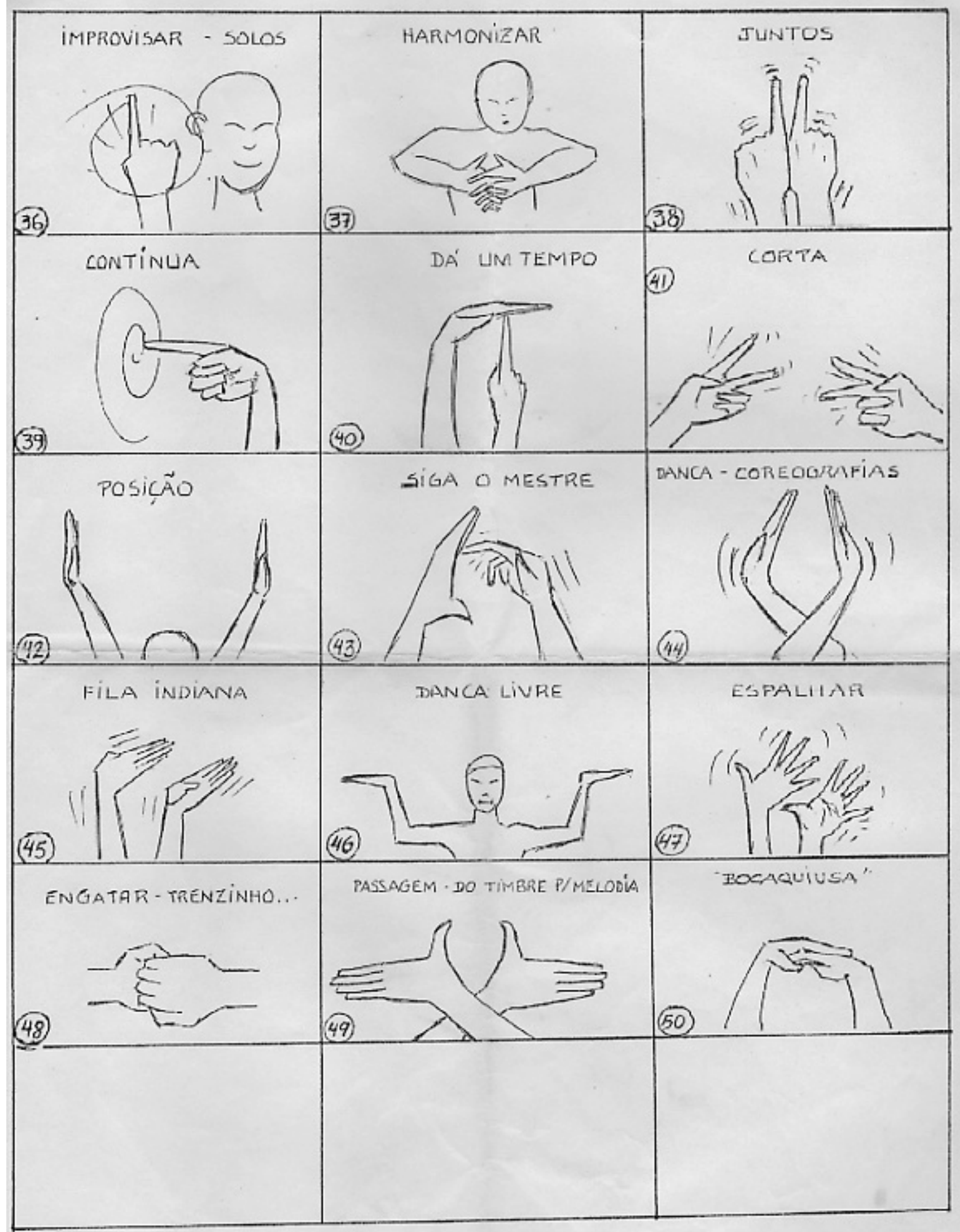




\section{PERCUSSAOV@CAL}

D F I C I A

\section{RELACAO DE ALGUNS EFEITOS PERCUSSIVOS-VOCAIS E SINAIS CORRESPONDENTES:}

1)

Y

- Som aspirado pelo nariz.

2)

3)

$\triangle$ - Som expirado pelo nariz.

4)

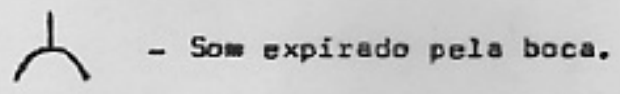

5)

7

- Som do "F", aspirado.

6)

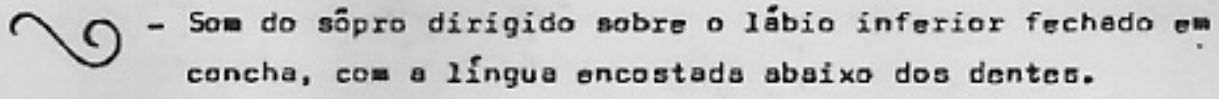

7)

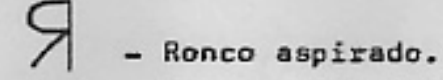

8)

- Batimento dos Iäbios em frequência, partindo do fanema "pó".

9) 2

- Assobio.

10)

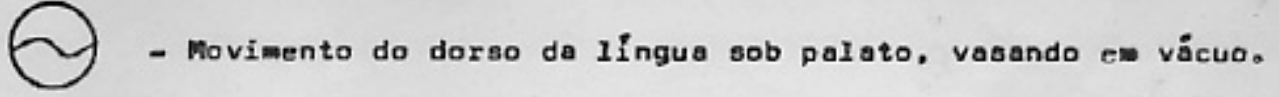

11)<smiles>CCC(C)C</smiles>

- Som empregado para expressar o "Não", formado pelo vácuo da letra "T".<smiles>c1ccccc1</smiles>

- Som do beijo agudo.

13)<smiles>C1CC2CCC1C2</smiles>

- Som do beija grave.

14)

(0) - Estalo da língua no céu da boca.

15)<smiles>[C]1CCCCCC1</smiles>

- Dedo indicador saindo da boca cob pressão ( "estouro da rôlha).

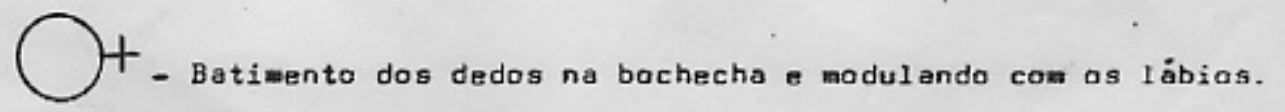


17)<smiles>CC1CCCCCCC1</smiles>

- Som da batida dos dedos da wão sobre os lábios, partindo do fonema "ర́", cos a garganta fechada.

1B)

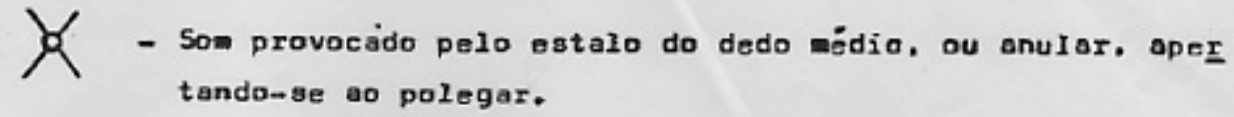

19) $\succ-E s t a l o$ do dedo indicador sobre os dedos médio polegar.

20) $\bigwedge 6 f$ - Sons de palma grave, médio a agudo.

21) 类 - Polma "estrela", com as wãos bem abertas.

22)

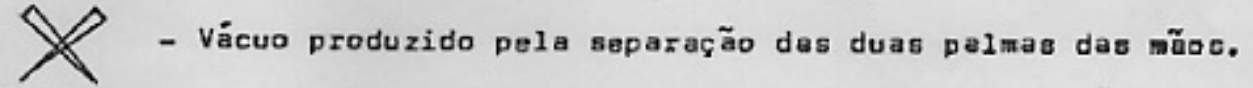

23)<smiles>C1CC1</smiles>

- Efeito de ressonância na boca, provocado pelo jato de ar, expulso pela palma.

24) $\langle\bigotimes$ - Efeito de ocarina com as mãos.

25) $\quad 7$ - Batimento das mãos sobre as pernas.

26)

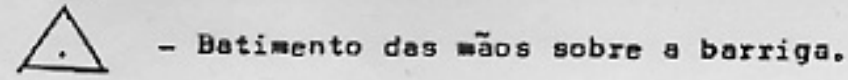

27)

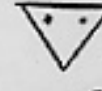

- Batimento das mãos sobre o peito.

28)

O - Harmônicos superiores graves ( Hum... nỐ).

29)

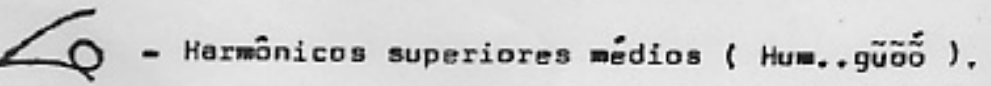

30)

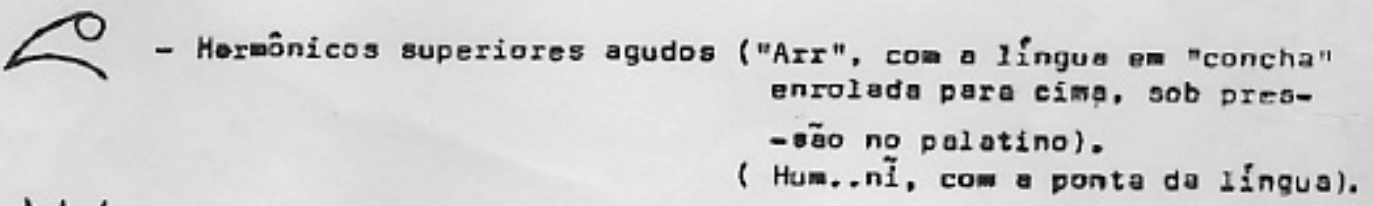

31)

- Som energético gutural indígena, "Hum", fechando a garganta.

32)<smiles>CC1(C)CCCCCC1</smiles>

- Grito energético "áraba" voz em falsete. com a línguo batendo ea frequência sobre o lábio superior. 
Primeiras notações musicais (Fernando Barba e André Hosoi)

\begin{tabular}{|c|c|c|c|}
\hline \multicolumn{4}{|c|}{ AITMOS USANDO PEITO, ESTALO E PALMA } \\
\hline palma estrela & paima costas de máo & paima na boca & $\begin{array}{l}\text { - A paima costas de máo náo é simetrica } \\
\text { como as demais. Como convencado, usaremos } \\
\text { a malo que recebe a palma como guia. }\end{array}$ \\
\hline
\end{tabular}

- A nota que está com um círculo representa a mão que começa o rnmo

tunk I

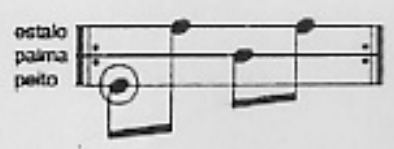

samba
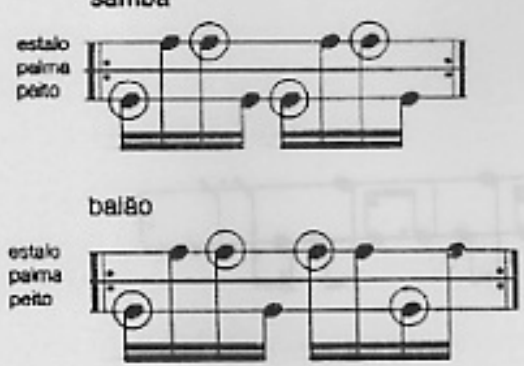

maracatu 1

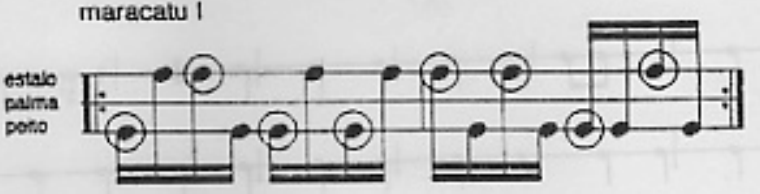

maracatu II

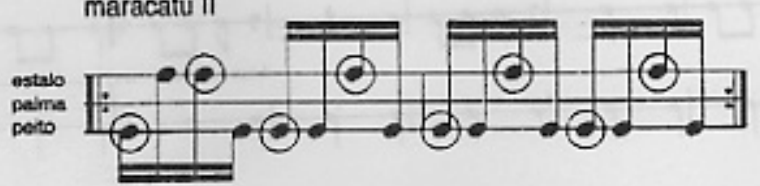

Funk Doido (fertrames suber)
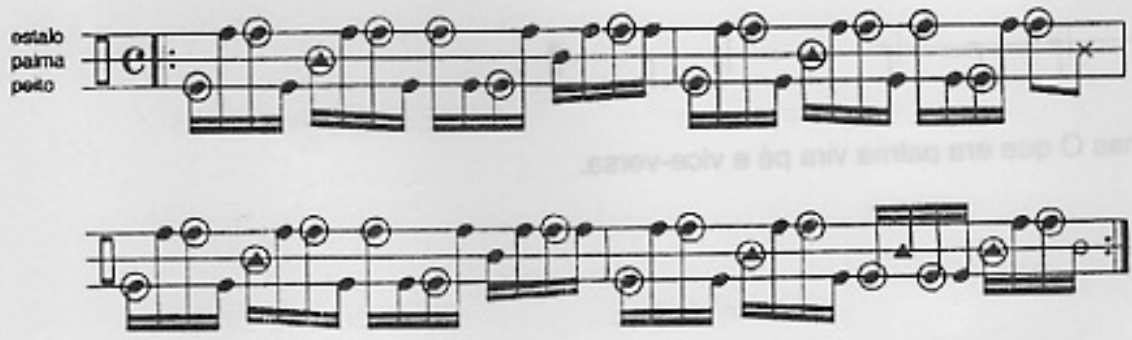

Aust Núciso Munalcal Tel: (v1) 3825877 
Ritmos peito estalo palmas

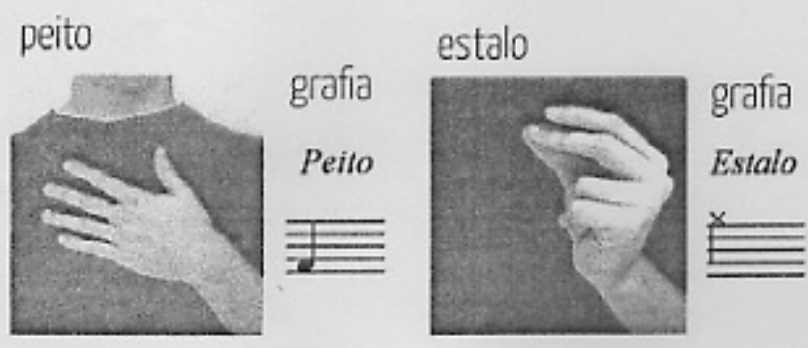

e - mão esquerda

d - mão direita

SHsico еи cacian - FUN

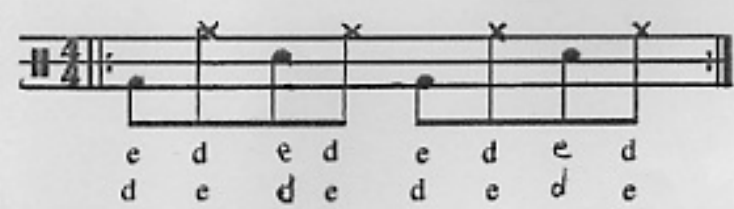

susa

\section{Fux stredousu}

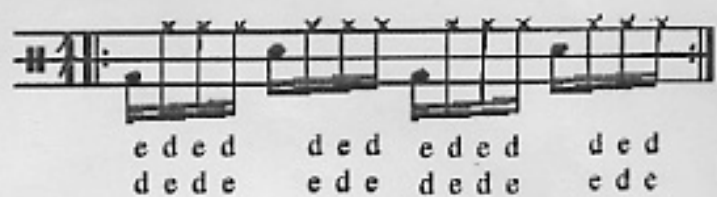

varuclo - 5a4sA soc

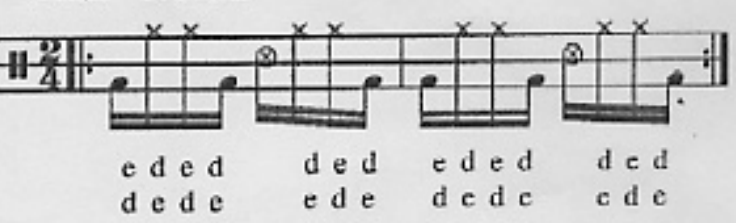

d e d e

e d e

$\begin{array}{ll}\text { ded e d e d e } & \text { e d e d e d }\end{array}$

e de d e de d

d e d e d ed e

VACUCL BAIRTO
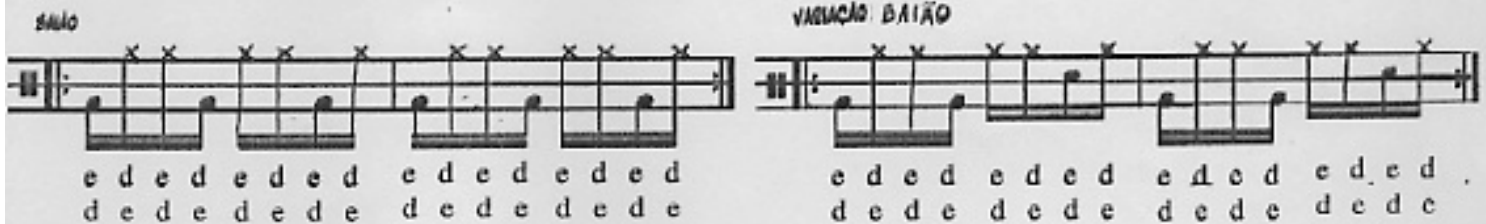

e d e d e d e d e d e d e d e d

$d e d e d e d e d e d e d e d e$

Os ritmos também podem ser praticados dividindo os participantes em dois grupos, um grupo executará uma ou mais vezes determinado ritmo e o outro grupo fará o mesmo logo em seguida, durante a pausa do primeiro grupo.

\section{Barbatuquesos}


2

www.barbatuques com.br

Visucio Sulo - (Guio Destevereudo)

II

II vinclo sinu

${ }^{16}$ Bassapals Q000V

20 Mendiru 1

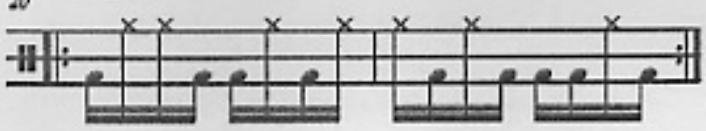

Manaru 2

FEV
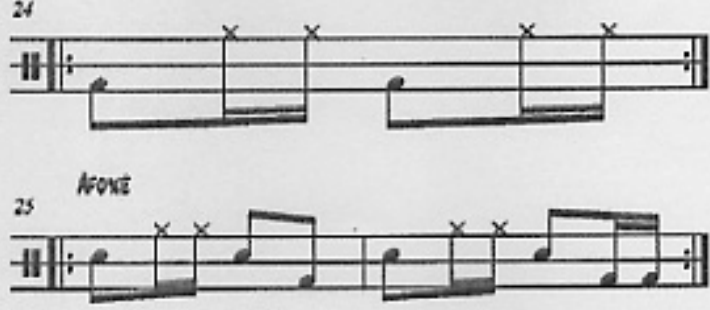

Sasa Macus - Casao veroe

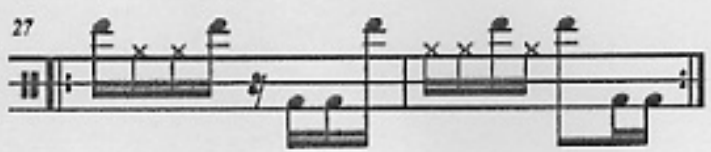

Material organizado por André Hosoí 


\section{Notações musicais (Carlos Bauzys)}

\section{Percussão Corporal}

Sugestões de:

"Bula da notaçäo"

Barbatuques

Carlos Bauzys

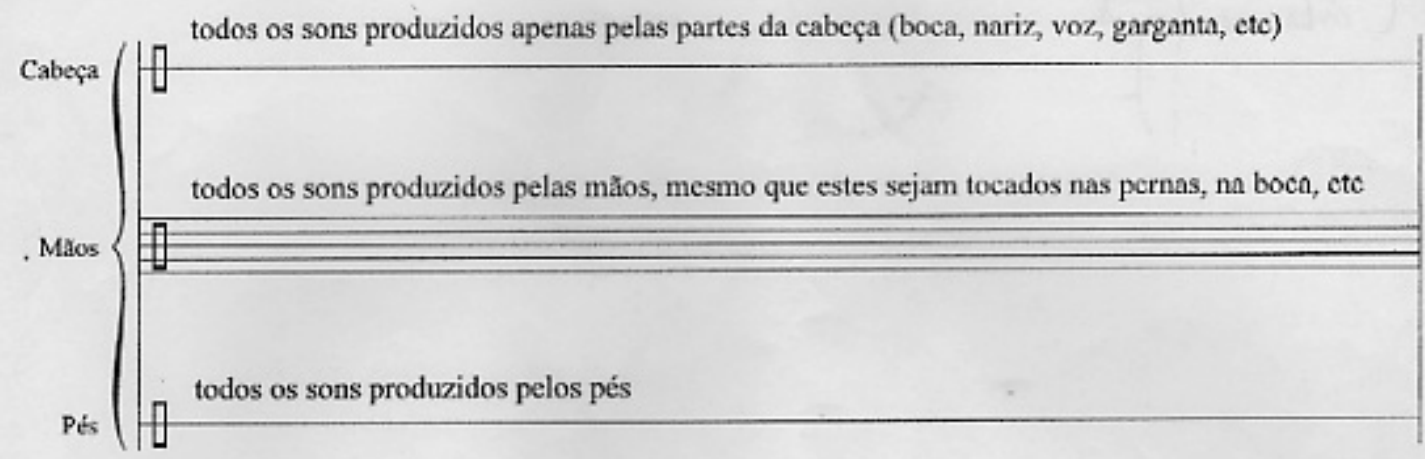

\section{*Mãos}

\section{Palmas}

\begin{tabular}{|c|c|c|c|c|c|c|c|}
\hline Estalada & Estrela & Concha & Peito da mão & Fudeu & Dois dedos & Impulso & Esfregada \\
\hline 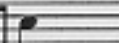 & $t^{\circ}$ & $p$ & $\theta^{2}$ & 5 & 80 & 79 & 15 \\
\hline
\end{tabular}

Peito Perna Barriga Estalo

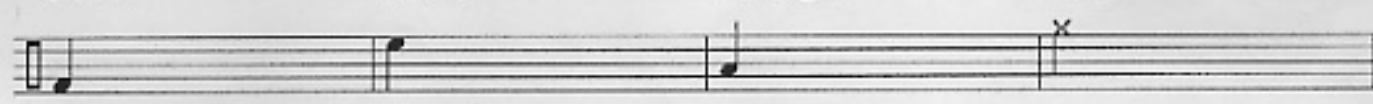

Mão na cabeça

(duas mãos

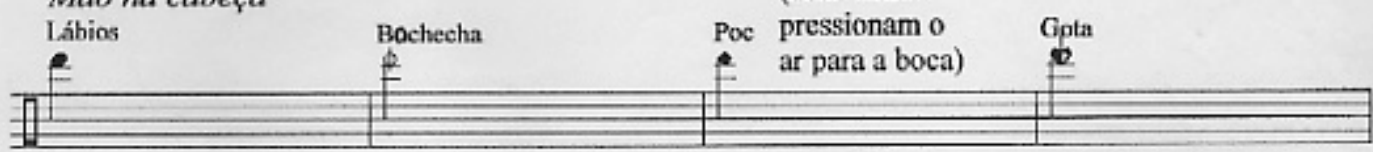

\section{*Cabeça}

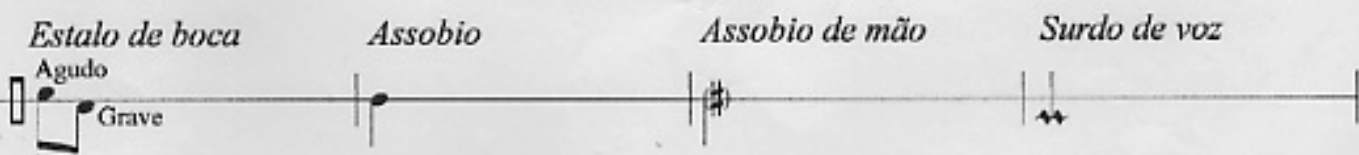

*Pés

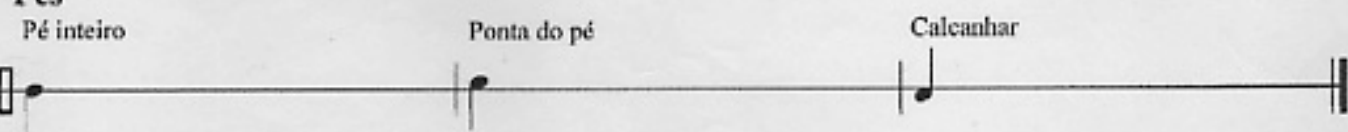

"Símbolos Extras

Mão ou pé forte

+ Som aberto (mais agudo)

- Som fechado (mais grave) 


\section{Percussão Corporal}

Transcrição: Carlos Bauzys

"Toques dados na Oficina da Oswald de Andrade"
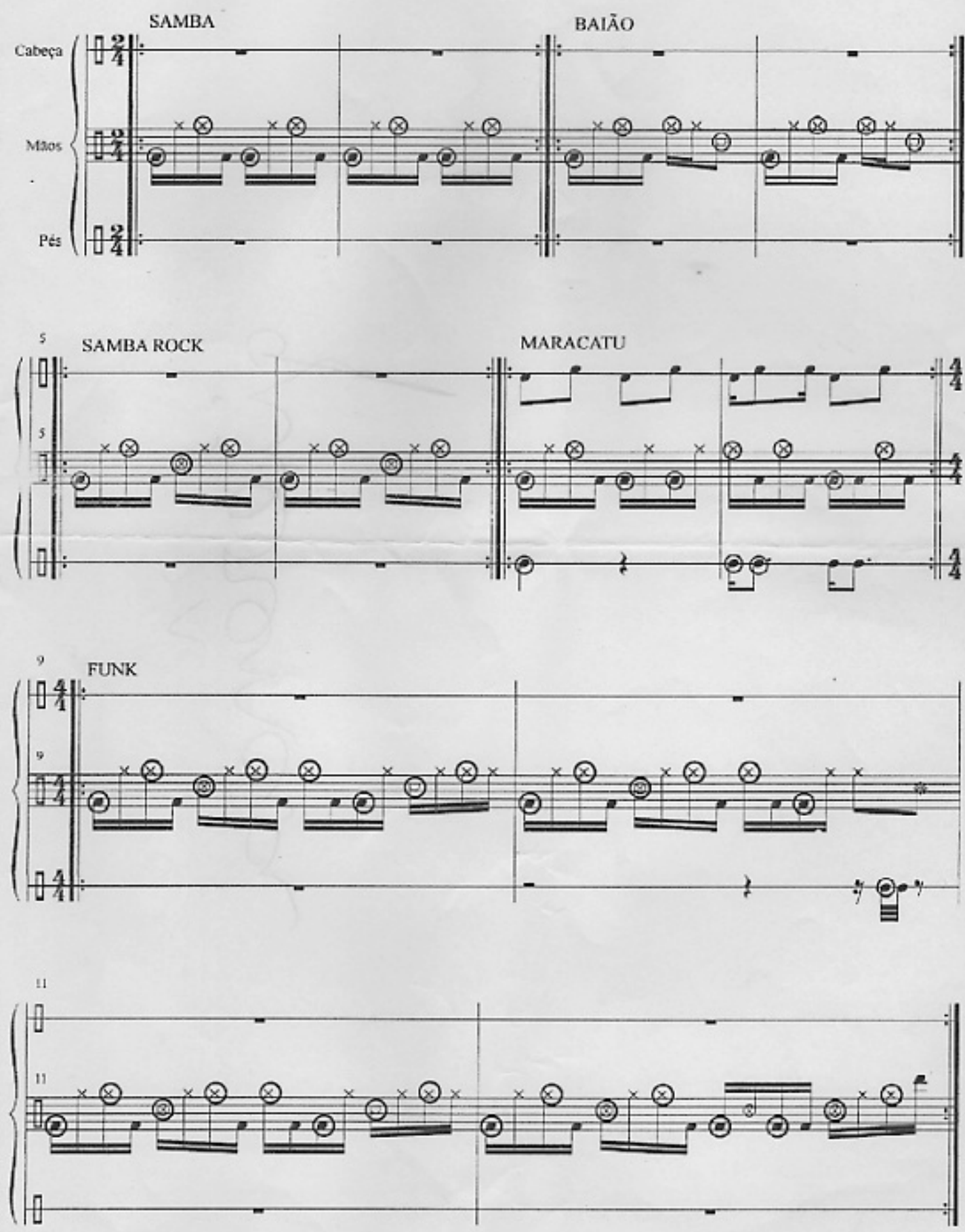


\section{Percussão Corporal \\ "Criações"}

Carlos Baurys

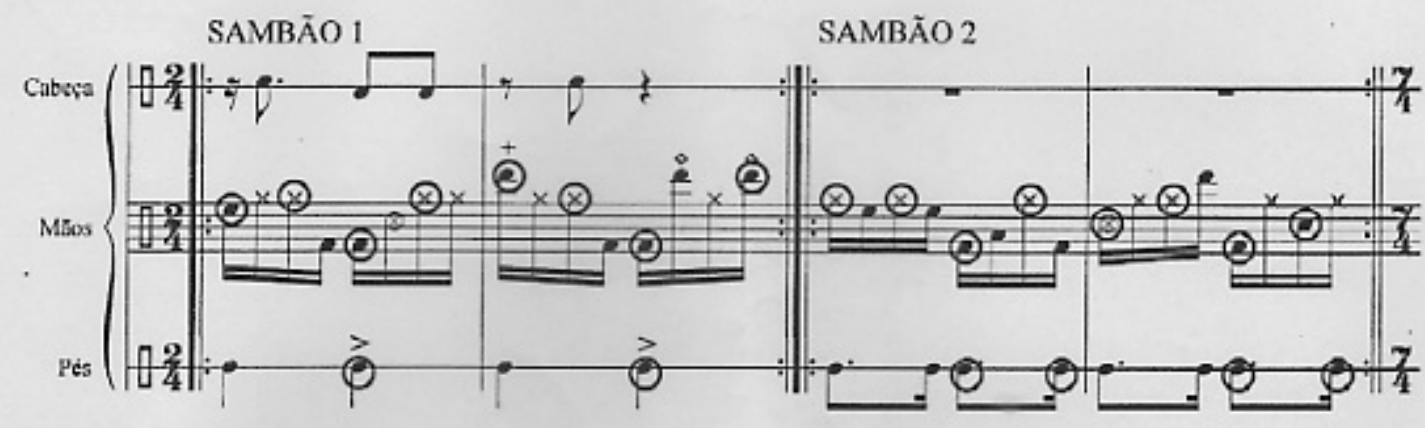

s SETE/ PÉS SINCOPADOS
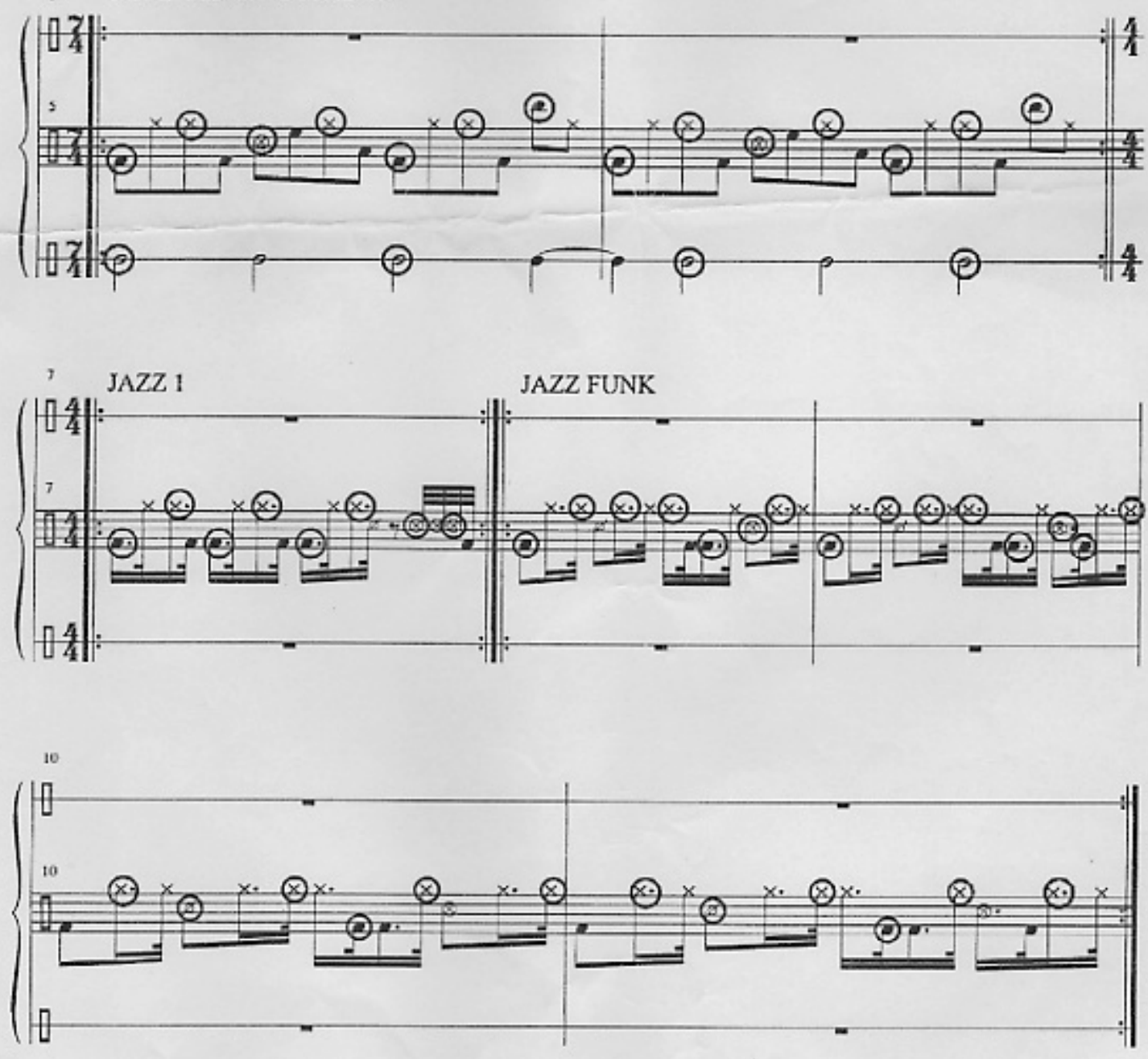
Barbapapa's Groove
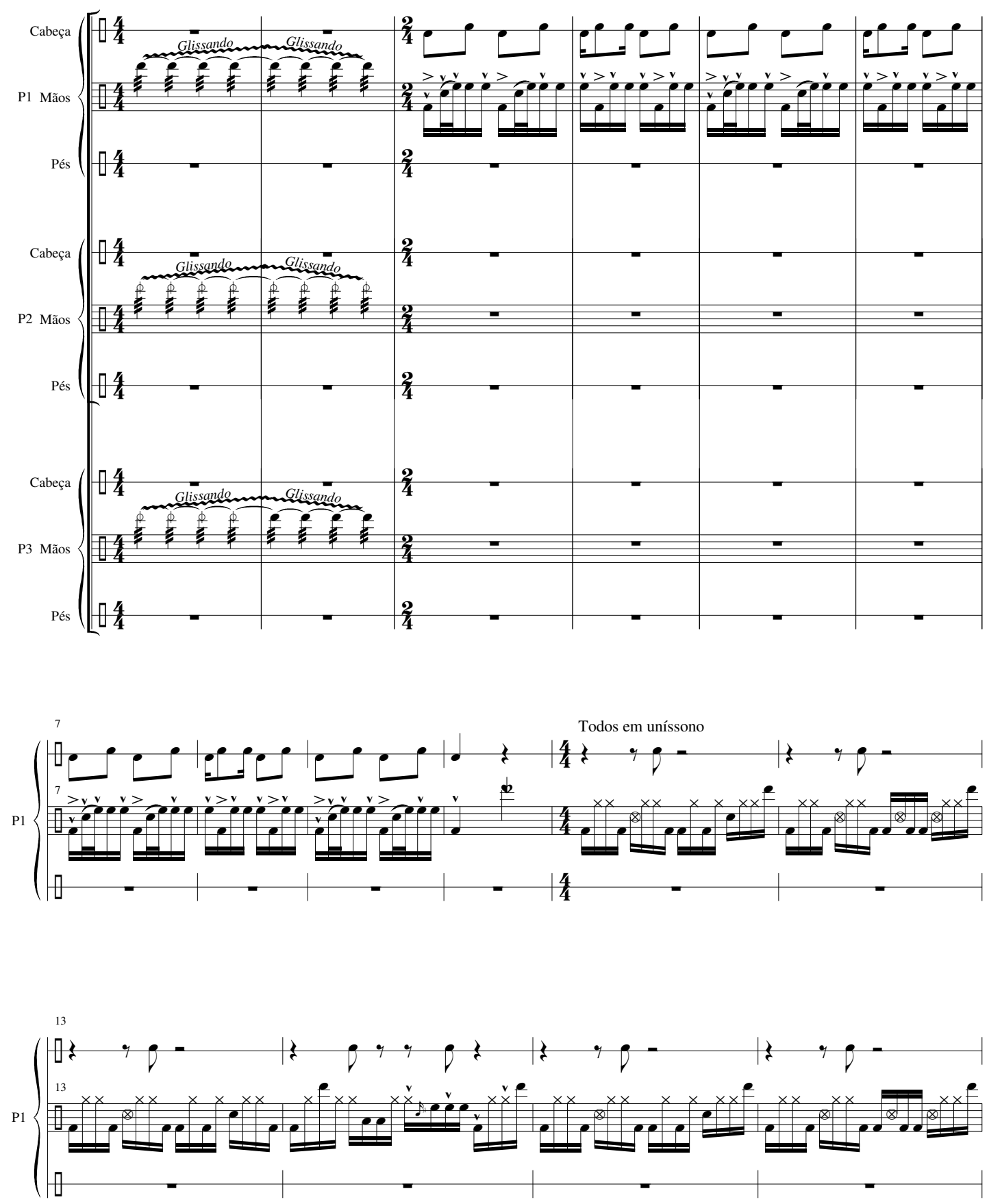

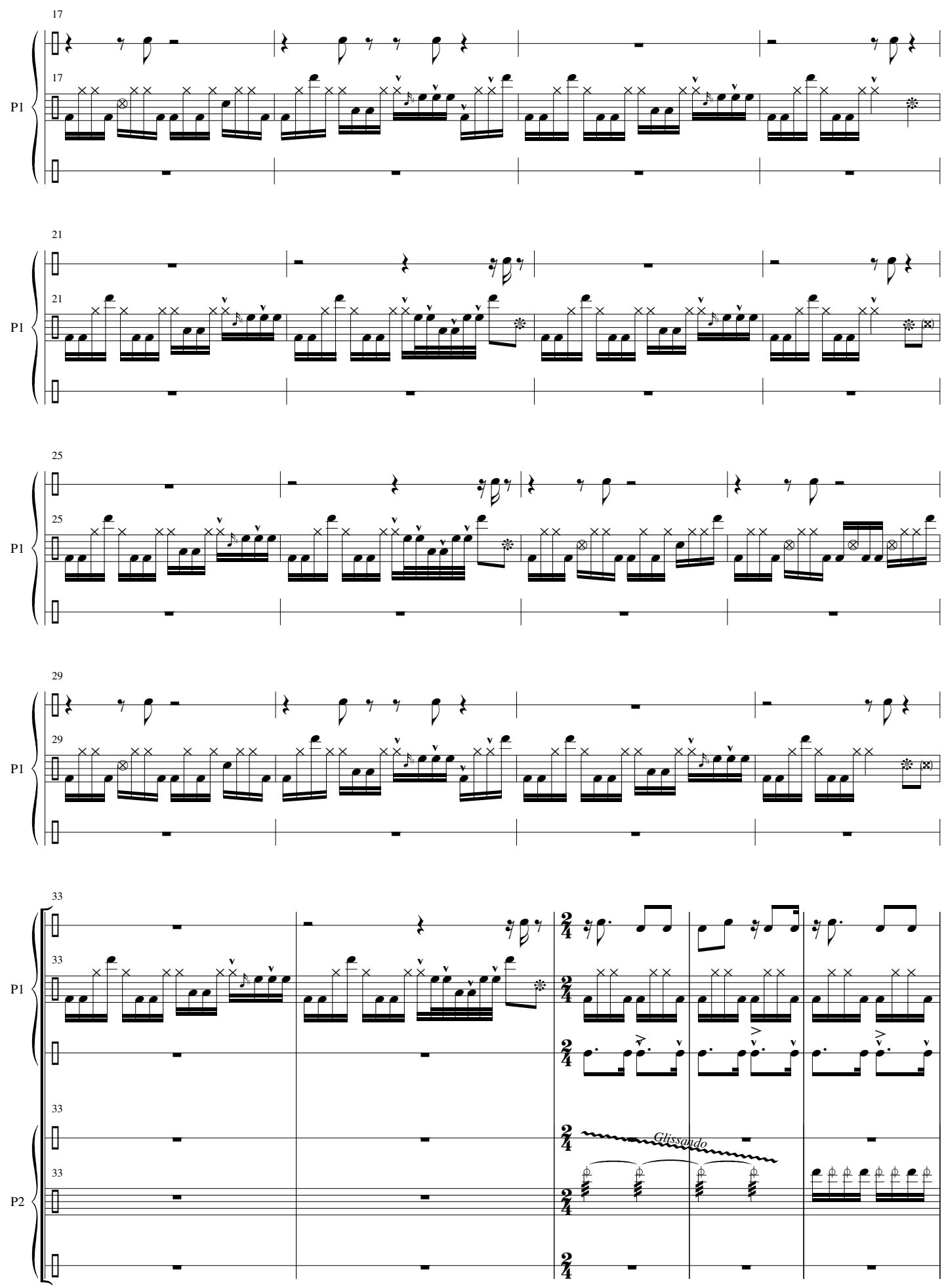

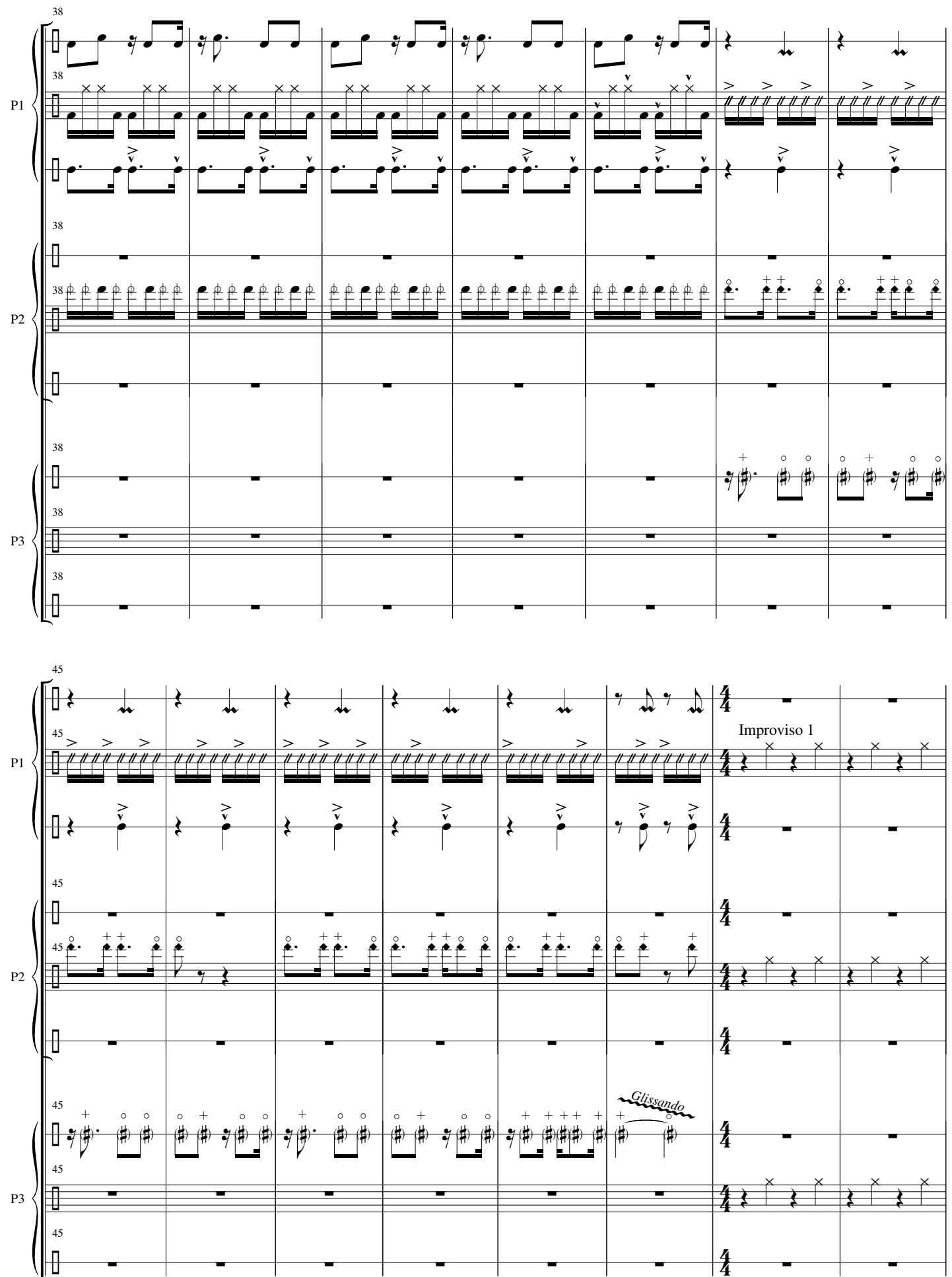

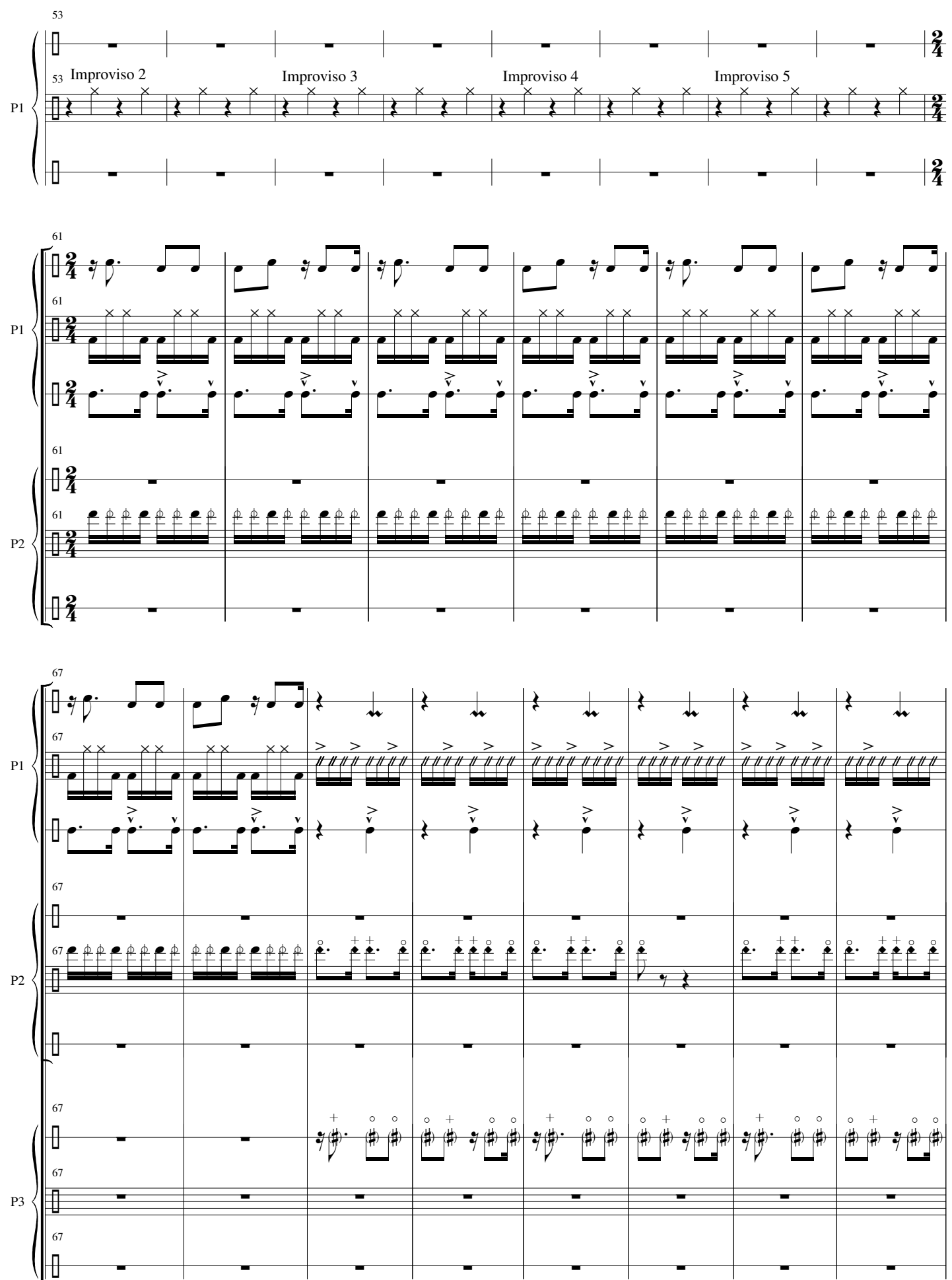

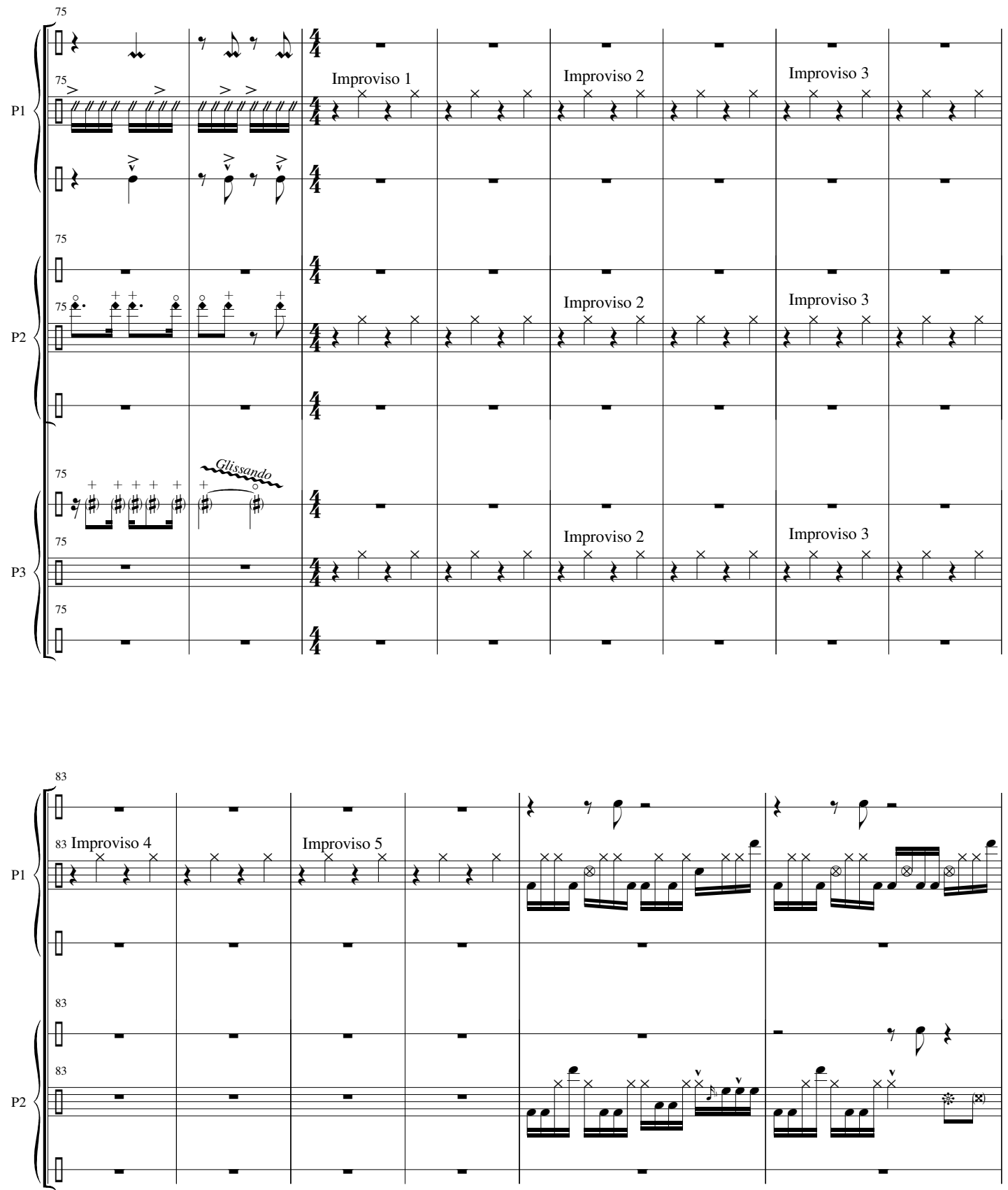

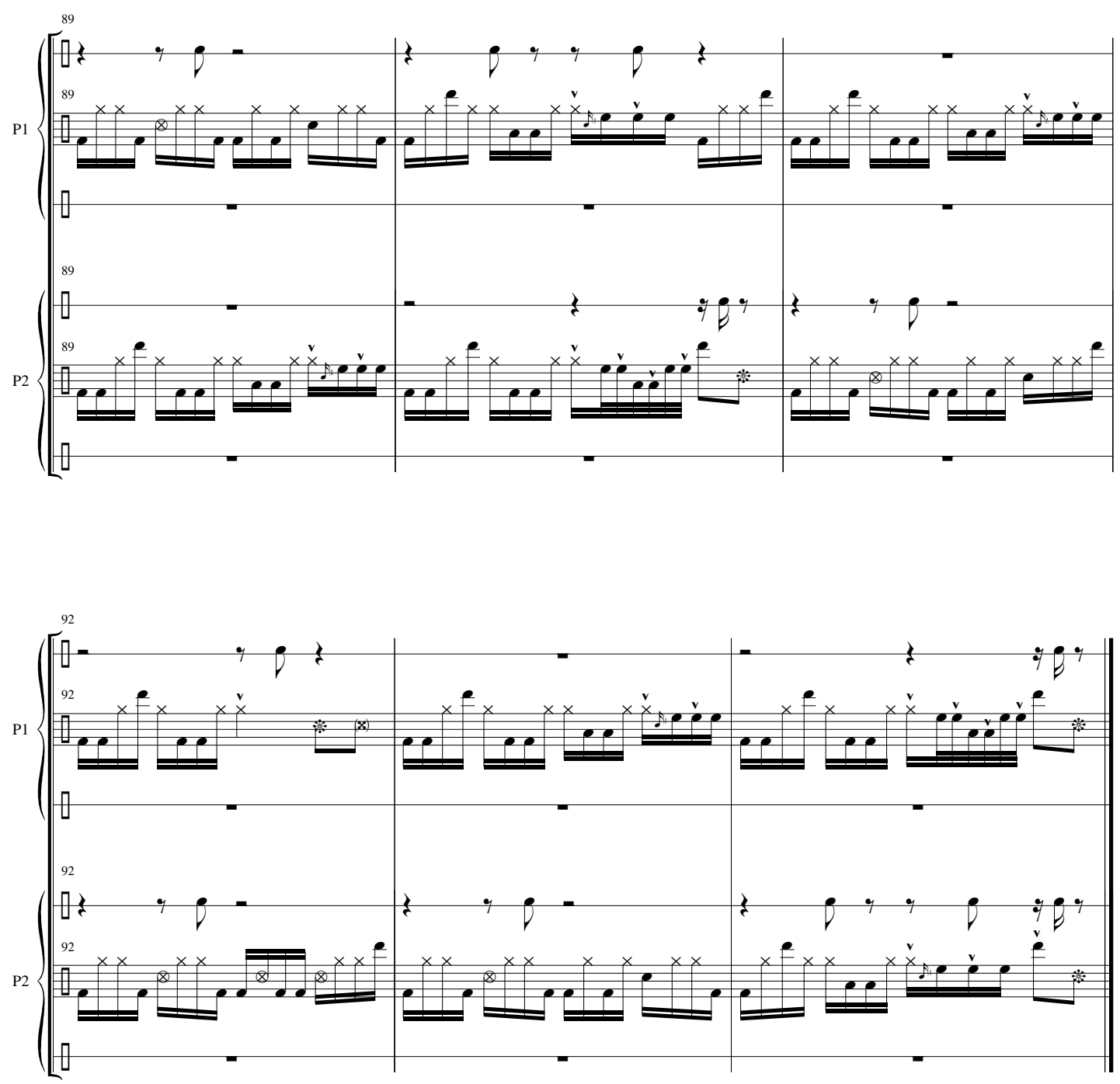